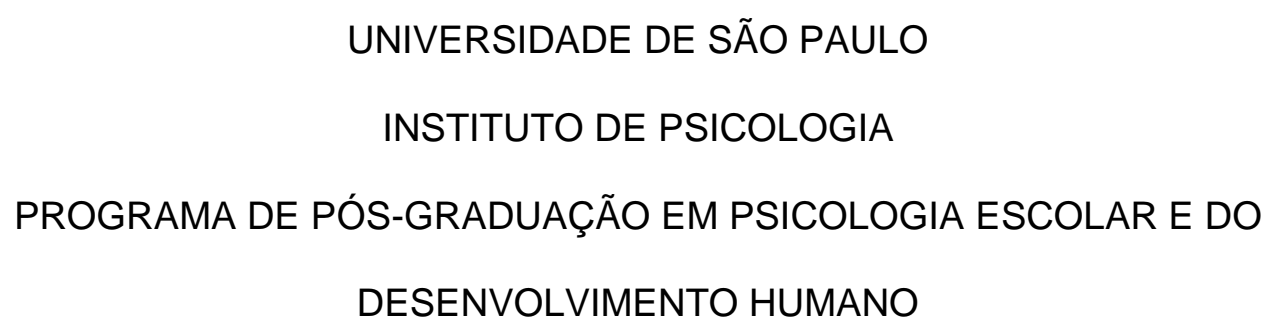

PAULO KEISHI ICHIMURA KOHARA

\title{
A instituição para o sujeito - metapsicologia da
} prática psicanalítica na instituição 
PAULO KEISHI ICHIMURA KOHARA

\section{A instituição para o sujeito - metapsicologia da prática psicanalítica na instituição}

Dissertação apresentada ao Instituto de Psicologia da Universidade de São Paulo como parte dos requisitos para obtenção do título de Mestre em Psicologia.

Área de Concentração: Psicologia Escolar e do Desenvolvimento Humano (PSA) / Instituições educacionais e formação do indivíduo.

Orientador: Prof. Doutor Paulo Cesar Endo 
AUTORIZO A REPRODUÇÃO E DIVULGAÇÃO TOTAL OU PARCIAL DESTE TRABALHO, POR QUALQUER MEIO CONVENCIONAL OU ELETRÔNICO, PARA FINS DE ESTUDO E PESQUISA, DESDE QUE CITADA A FONTE.

Catalogação na publicação

Biblioteca Dante Moreira Leite

Instituto de Psicologia da Universidade de São Paulo

Kohara, Paulo Keishi Ichimura.

A instituição para o sujeito: - metapsicologia da prática psicanalítica na instituição / Paulo Keishi Ichimura Kohara; orientador Paulo César Endo -- São Paulo, 2009.

$154 \mathrm{p}$.

Dissertação (Mestrado - Programa de Pós-Graduação em Psicologia. Área de Concentração: Psicologia Escolar e do Desenvolvimento Humano) - Instituto de Psicologia da Universidade de São Paulo.

1. Constituição do sujeito 2. Organizações 3. Psicanálise Instituições 4. Metapsicologia 5. Atendimento psicanalítico I. Título.

RC504 


\section{FOLHA DE APROVAÇÃO}

PauloKeishi Ichimura Kohara

A instituição para o sujeito - metapsicologia da prática psicanalítica na instituição

Dissertação apresentada ao Instituto de Psicologia da Universidade de São Paulo como parte dos requisitos para obtenção do título de Mestre em Psicologia.

Área de Concentração: Psicologia Escolar e do Desenvolvimento Humano (PSA) / Instituições educacionais e formação do indivíduo.

BANCA EXAMINADORA:

Prof. Dr.

Instituição: Assinatura:

Prof. Dr.

Instituição: Assinatura:

Prof. Dr.

Instituição: Assinatura:

Dissertação defendida e aprovada em: I 
A todos que confiaram a mim suas histórias e me tornaram não só um psicólogo como uma pessoa melhor. 


\section{Agradecimentos}

Ao Paulo Cesar Endo, pela orientação presente e atenciosa e por tudo que me ensinou durante aulas, discussões e conversas. Mais do que fundamental para a construção deste trabalho, sua maneira de transmitir o conhecimento foi o que fez despertar em mim a paixão pela Psicanálise.

Aos professores Miriam Debieux e Manoel Berlinck pela rica contribuição intelectual oferecida no exame de qualificação, pela generosidade nas palavras escolhidas e pela possibilidade de uma nova discussão no momento da defesa. Vossa leitura, atenta e crítica, foi importante para o desenvolvimento deste trabalho e também deste pesquisador.

Aos professores Maria Cristina Vicentin, Paulo Albertini, Léia Priszkulnik, Maria Júlia Kovács por aceitarem receber e ler este trabalho. Apesar do limite formal de membros efetivos das bancas, foi um prazer contar com vocês para a suplência e uma honra poder submeter minha produção à vossa apreciação.

Aos meus companheiros de orientação, Helena, Mathias, Rose, Polyana, Karina, Maikel, Zé Ricardo, Natália, Flávia, Lygia e Camila, pela leitura crítica, mas ao mesmo tempo benevolente dos meus textos em formação. Sem a contribuição de vocês o texto não se tornaria o inteiro que é hoje.

Às minhas supervisoras, Gê, Abigail, Cris, Maria Júlia e Vera Stela, cujos ensinamentos me fizeram descobrir a paixão pelo trabalho clínico. Às professoras Dora e Tereza por terem me ensinado o amor pela pesquisa. A todos que foram meus colegas de trabalho no Curso Pré-Universitário Psico-USP, por terem compartilhado comigo e feito nascer minha paixão pelo trabalho institucional. À minha analista Luciana, por ter me ajudado a conciliar todas as minhas paixões e também as decepções. 
À minha família pela paciência e companheirismo, pelo cuidado com minha saúde física e mental, pelo suporte nos momentos mais difíceis vividos durante esse mestrado. Sem precisar saber do conteúdo desse trabalho, mãe, pai, tia (Edna), Lucas e Yujy, a presença de vocês foi fundamental para que eu pudesse realizá-lo.

Aos meus amigos, sem os quais não conseguiria enfrentar as tempestades que a vida nos apresenta. Amigos da Rep Quinto Elemento, amigos de celebrações pré-natalinas, meus poucos e bons amigos de faculdade e de cursinho, minha prima querida do outro lado do mundo, meus novos e já bons amigos de CREAS, mesmo que nossos caminhos talvez deixem de se cruzar, seja pela distância, seja pelos caminhos que a vida nos leva a tomar, saibam que vocês não só fazem parte do que possibilitou esse trabalho, mas fazem parte do que eu sou. Deixo um agradecimento especial a dois grandes amigos, Bruno e Karina, cuja presença e amizade no momento mais difícil dessa jornada, me deu forças para que este trabalho continuasse.

A CAPES e ao Programa de Pós Graduação em Psicologia Escolar e do Desenvolvimento Humano do IPUSP, pela bolsa que durante grande parte desse trabalho permitiu que eu me dedicasse exclusivamente a pesquisa e possibilitou que o trabalho fosse concluído em dois anos. 
"Agora, concluindo, tocarei de relance numa situação que pertence ao futuro - situação que parecerá fantástica a muitos dos senhores, e que, não obstante, julgo merece que estejamos com as mentes preparadas para abordá-la. Os senhores sabem que as nossas atividades terapêuticas não têm um alcance muito vasto. Somos apenas um pequeno grupo e, mesmo trabalhando muito, cada um pode dedicar-se, num ano, somente a um pequeno número de pacientes. Comparada à enorme quantidade de miséria neurótica que existe no mundo, e que talvez não precisasse existir, a quantidade que podemos resolver é quase desprezível. Ademais, as nossas necessidades de sobrevivência limitam o nosso trabalho às classes abastadas, que estão acostumadas a escolher seus próprios médicos e cuja escolha se desvia da psicanálise por toda espécie de preconceitos. Presentemente nada podemos fazer pelas camadas sociais mais amplas, que sofrem de neuroses de maneira extremamente grave.

Vamos presumir que, por meio de algum tipo de organização, consigamos aumentar os nossos números em medida suficiente para tratar uma considerável massa da população. Por outro lado, é possível prever que, mais cedo ou mais tarde, a consciência da sociedade despertará, e lembrar-se-á de que o pobre tem exatamente tanto direito a uma assistência à sua mente, quando o tem, agora, à ajuda oferecida pela cirurgia, e de que as neuroses ameaçam a saúde pública não menos do que a tuberculose, de que, como esta, também não podem ser deixadas aos cuidados impotentes de membros individuais da comunidade. Quando isso acontecer, haverá instituições ou clínicas de pacientes externos, para as quais serão designados médicos analiticamente preparados, de modo que homens que de outra forma cederiam à bebida, mulheres que praticamente sucumbiriam ao seu fardo de privações, crianças para as quais não existe escolha a não ser o embrutecimento ou a neurose, possam tornar-se capazes, pela análise, de resistência e de trabalho eficiente. Tais tratamentos serão gratuitos. Pode ser que passe um longo tempo antes que o Estado chegue a compreender como são urgentes esses deveres. As condições atuais podem retardar ainda mais esse evento. Provavelmente essas instituições iniciar-se-ão graças à caridade privada. Mais cedo ou mais tarde, contudo, chegaremos a isso. Defrontar-nos-emos, então, com a tarefa de adaptar a nossa técnica às novas condições. Não tenho dúvidas de que a validade das nossas hipóteses psicológicas causará boa impressão também sobre as pessoas pouco instruídas, mas precisaremos buscar as formas mais simples e mais facilmente inteligíveis de expressar as nossas doutrinas teóricas. Provavelmente descobriremos que os pobres estão ainda menos prontos para partilhar as suas neuroses do que os ricos, porque a vida dura que os espera após a recuperação não lhes oferece atrativos, e a doença dá-lhes um direito a mais à ajuda social. Muitas vezes, talvez, só poderemos conseguir alguma coisa combinando a assistência da mente com certo apoio material, à maneira do Imperador José. É muito provável, também, que a aplicação em larga escala da nossa terapia nos force a fundir o ouro puro da análise livre com o cobre da sugestão direta; e também a influência hipnótica poderá ter novamente seu lugar na análise, como o tem no tratamento das neuroses de guerra. No entanto, qualquer que seja a forma que essa psicoterapia para o povo possa assumir, quaisquer que sejam os elementos dos quais se componha, os seus ingredientes mais efetivos e mais importantes continuarão a ser, certamente, aqueles tomados à psicanálise estrita e não tendenciosa". [Freud, 1918-19, Progressos da Terapia Analítica, p.210-11]. 


\section{RESUMO}

KOHARA, P. K. I. A instituição para o sujeito: metapsicologia da prática psicanalítica na instituição. São Paulo, 2009. 154f. Dissertação (Mestrado) - Instituto de Psicologia, Universidade de São Paulo, São Paulo, 2009.

O presente trabalho tem por objetivo problematizar as relações entre psicólogo, paciente e situação institucional nos atendimentos de base psicanalítica realizados no interior de instituições heterogêneas à psicanálise. Nossa investigação parte das seguintes questões: a) como a dimensão institucional é apreendida pelo sujeito e como essa apreensão se reflete na situação analítica; b) como a relação analítica se insere num contexto institucional estranho e quais as conseqüências dessa inserção; c) quais os procedimentos técnicos possíveis para a prática do psicanalista nessas condições. Discutimos, então, quais as condições clínico-teóricas que ora possibilitam, ora não, o exercício da prática psicanalítica nas instituições. A partir de textos da metapsicologia investigamos quais as condições da transferência na instituição e seus desdobramentos tanto para o paciente quanto para o terapeuta e qual a influência das condições institucionais na dinâmica inconsciente instaurada entre terapeuta, paciente e situação analítica. Discutimos como a transferência se manifesta no interior das instituições, quais são os recursos que o psicanalista dispõe para trabalhar com essa dinâmica transferencial, como podemos diferenciar metapsicologicamente as instituições das organizações, como se constitui e se configura a dinâmica inconsciente entre o sujeito e as instituições sociais, como a psicanálise se caracteriza também como uma instituição nesses atendimentos. Por fim, nos propusemos a fazer um ensaio, com o auxílio de duas vinhetas clínicas, sobre como a investigação conceitual que realizamos poderia aparecer em casos singulares de atendimentos em instituições, oferecendo alternativas de compreensão para casos em que, de alguma forma, a condição institucional ofereceu resistência ao processo. Concluímos que o trabalho nas instituições exige do psicanalista uma disposição de analisar sua própria condição de pertencimento a elas, bem como a compreensão de que a cena transferencial não se localiza apenas no setting de atendimento. Como suporte transferencial, a instituição oferece também a uma possibilidade singular de elaboração das pulsões parciais, na medida em que pode ser depositária de uma unidade de uma potência que extrapolam as possibilidades das condições clássicas de enquadramento. Frente às limitações e alternativas, a identidade de uma prática psicanalítica nas instituições configura-se como uma atuação possível, porém desafiadora aos psicanalistas.

Palavras-chave: Constituição do sujeito; organizações; psicanálise - instituições; metapsicologia; atendimento psicanalítico. 


\begin{abstract}
KOHARA, P. K. I. The institution for the subject: metapsychology of the psychoanalytic practice in the institution. São Paulo, 2009. 154f. Dissertation (Master dagree) - Instituto de Psicologia, Universidade de São Paulo, São Paulo, 2009.
\end{abstract}

The aim of the present study is to discuss the relationship among psychologist, patient and institutional situation at the assistence of psychoanalytic approach carried out inside institutions heterogeneous to the psychoanalysis. Our investigation starts from the following questions: a) how the institutional dimension is learned by the subject and how this is reflected in the analytical situation; b) how the analytical situation inserts in a strange institutional context and which are the consequences of this insertion; c) what are the possible technical proceeds for the practice of the psychoanalyst in these conditions. We then discuss which are the clinical-theoretical conditions that one time permit, and other time not, the exercise of the psychoanalytical practice in the institutions. From texts of metapsychology we investigate which are the conditions of the transference in the institution and their unfoldings as much for the patient as for the therapist and what the influence of the institutional conditions in the incontinent dynamic established among therapist, patient and analytical situation. We discuss how the transference manifests inside the institutions, which are the resources that the psychoanalyst has to work with this transference dynamics, how we can metapsychologically differentiate the institutions from the organizations, how constitute and configure the unconscious dynamic among the subject and the social institutions, how the psychoanalysis also characterizes as an institution in these treatments. Finally, we proposed to do a essay, with the assistance of two clinical vignette, about how the conceptual investigation that we carried out could appear in singular cases of treatment in institutions, offering alternatives of comprehension for cases where in some way the institutional condition offered resistance for the process. We conclude that the work in the institutions demands disposition from the psychoanalyst to analyze his own condition of belonging to the institutions, as well as the comprehension that the transference scene isn't only in the treatment setting. As transference support, the institution also offers the singular possibility for the elaboration of the partial pulsation, in the measure where it can be depositary of a unit of power that surpasses the possibilities of the classical conditions of framing. In front of the limitations and alternatives, the identity of a psychoanalytic practice in the institutions configures as a possible however challenging performance to the psychoanalysts.

Key-words: Constitution of the subject; Organizations; Psychoanalysis - Institutions; Metapsychology; Psychoanalytic Assistence. 


\section{Sumário}

1. INTRODUÇÃO

2. A SITUAÇÃO ANALÍTICA INSTITUCIONAL: UM ESTUDO DA TRANSFERÊNCIA........................................... 18

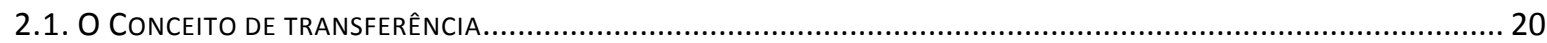

2.2. TRANSFERÊNCIA POSITIVA E TRANSFERÊNCIA NEGATIVA - CONSIDERAÇÕES SOBRE A DINÂMICA PULSIONAL ..............28

2.3. A ORGANIZAÇÃO FANTASMÁTICA E A TÓPICA DO INCONSCIENTE - CONSIDERAÇÕES SOBRE A ESTRUTURA DA CENA

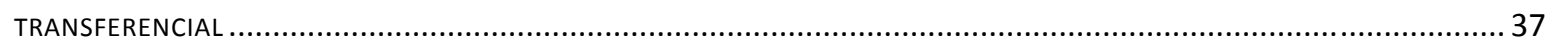

2.4. A tRANSFERÊNCIA DE TRANSFERÊNCIA E OS PAPÉIS INSTITUÍDOS - O(S) PAPEL(IS) REPRESENTADO(S) PELO ANALISTA 47

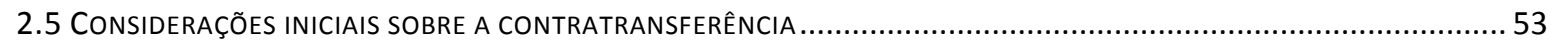

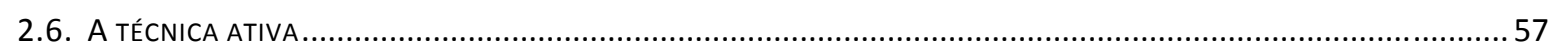

2.7. A ELASTICIDADE DA TÉCNICA PSICANALÍTICA: TATO PSICOLÓGICO E PRÍNCÍPIO DE RELAXAMENTO............................64

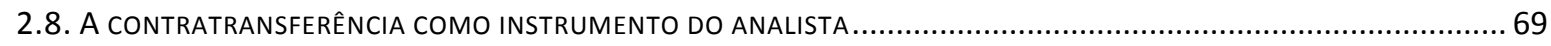

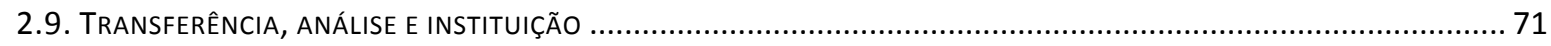

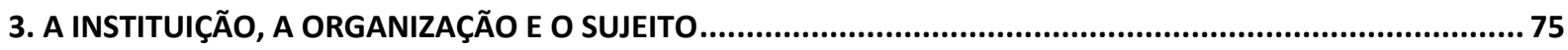

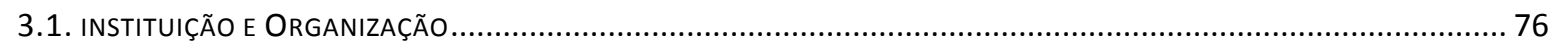

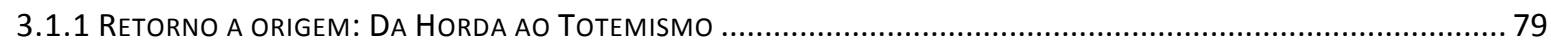

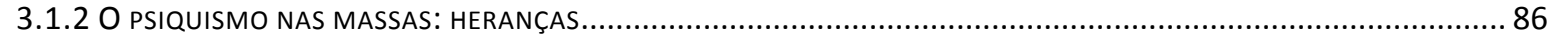

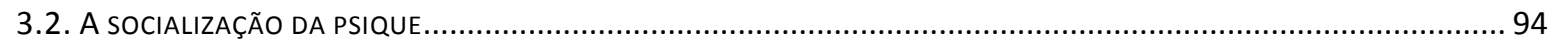

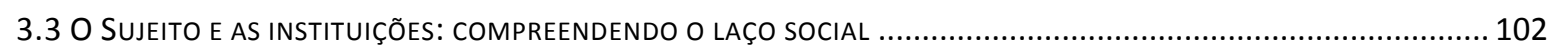

3.4. O ENQUADRE PSICANALÍTICO COMO INSTITUIÇÃO E COMO ORGANIZAÇÃO ....................................................... 108

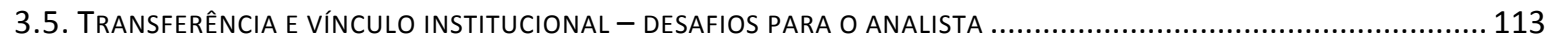

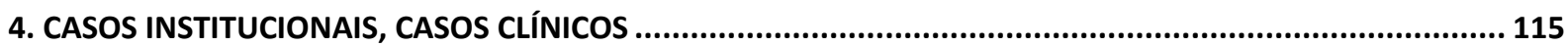

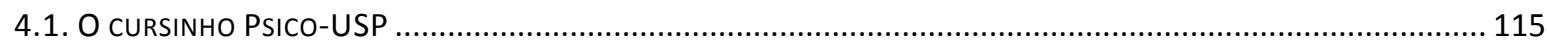

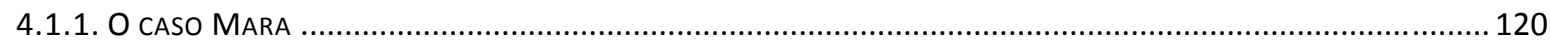

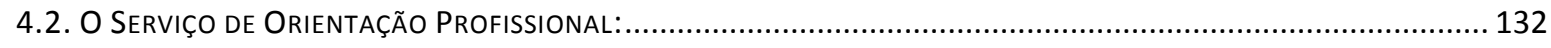

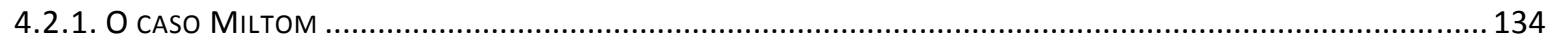

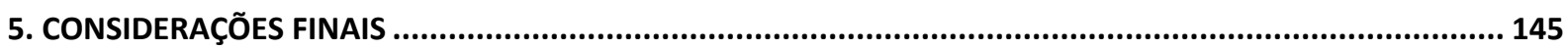

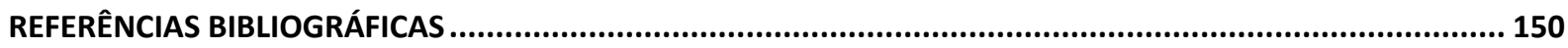




\section{Introdução}

O problema e o objeto sobre o qual se debruçará este trabalho será a prática psicanalítica nas instituições. A prática psicanalítica a que nos referimos é a psicanálise enquanto dispositivo de intervenção terapêutica, voltada para os sujeitos e não para as instituições. Entretanto, devemos desde já fazer o seguinte esclarecimento: se este é o objeto de nosso estudo e a referência de nossa situação problema, a investigação que desenvolveremos acerca de como os processos institucionais interferem nesta prática psicanalítica será conduzida em um outro campo: o da interface entre psicanálise e cultura.

O campo aberto pela expressão psicanálise e cultura ainda é bastante amplo para localizarmos nosso trabalho. Refere-se tanto à leitura psicanalítica da cultura e de seus fenômenos, quanto à contextualização da psicanálise na cultura, ambos, setores bastante abrangentes $^{1}$. Nosso estudo localiza-se no campo da leitura psicanalítica da cultura e, dentro deste, faremos dois exercícios: o de compreender um determinado fenômeno da cultura (os atendimentos de orientação psicanalítica nas instituições) a partir da leitura psicanalítica e o de analisar como este é influenciado pela ligação mais abrangente entre sujeito e cultura.

Como a inserção da psicanálise na cultura não será o foco de abordagem deste trabalho, façamos apenas um sobrevôo sobre o contexto em que nos inserimos. A interface entre psicanálise e instituições abarca também um campo abrangente de estudo que nasceu a partir da construção da própria instituição psicanalítica. Marcada por uma história de rupturas, a institucionalização do movimento psicanalítico vai desde a criação de uma instituição organizada, a IPA, seu desenvolvimento, até a transcendência da psicanálise como uma

\footnotetext{
${ }^{1}$ Como exemplos desses campos, temos as investigações sobre a formação da cultura, as produções da cultura, a formação do sujeito, a história do movimento psicanalítico e a epistemologia em psicanálise. Encontramos em Mezan (2002) uma discussão mais pormenorizada dessa interface.
} 
instituição reconhecida socialmente para além de uma organização centralizadora que a represente ${ }^{2}$. O desenvolvimento da psicanálise é concomitante ao estreitamento de sua relação com as demandas institucionais, uma vez que não teríamos a psicanálise como ela é hoje, se os psicanalistas não tivessem consolidado institucionalmente suas descobertas. A consolidação institucional da psicanálise desdobrou-se também em uma interface com outras instituições, como as universidades e as instituições de saúde mental que passaram a absorver psicanalistas, e com o campo de análise das instituições interessado nos processos inconscientes das formações institucionais ${ }^{3}$.

É dentro desse contexto da inserção do psicanalista em outros contextos institucionais de atuação que parte nosso trabalho, mas ainda assim estamos interessados em um recorte específico dessa atuação. Dentro das diversas demandas que a atuação nas instituições nos convoca a responder, tentaremos um caminho que nos permita discutir a atuação do psicanalista quando este é convocado a cuidar, tratar ou de alguma outra maneira atuar psicanaliticamente em nome da instituição e não a tendo como objeto. Dessa maneira, os processos inconscientes da instituição só nos interessam na medida em que afetam esse procedimento. Também nos diferenciamos aqui de um recorte comum utilizado no estudo sobre a atuação do psicanalista nas instituições: não nos interessam as especificidades deste ou daquele tipo de instituição, mas a condição institucional. As especificidades surgirão como tema apenas quando olharmos para os casos onde então, de maneira singular, emergem tanto

\footnotetext{
${ }^{2}$ Reconhecemos a importância da história da institucionalização psicanalítica dentro do nosso campo de estudo, mas um maior desenvolvimento do assunto nos desviaria de nosso recorte e ainda assim seria insuficiente para dar conta da complexidade dele. Deixamos então algumas referências para uma introdução ao tema. Sobre algumas das rupturas significativas para o nascimento e desenvolvimento da psicanálise, ver Endo (2001), Plom (2002) e Berlinck (2000). Sobre o nascimento da IPA, ver Ferenczi (1911/1991). Sobre a condição contemporânea da instituição psicanalítica, ver Berlinck (2000) e Volnovich (2002).

${ }^{3}$ Sobre a psicanálise nas instituições ver Lima e Altoé (2005), Soares (2007) e Revista Psicologia USP (2001).
} 
sujeito quanto instituição. Em nosso enfoque, a instituição deixa de ser a constante, sobre a qual se apóiam os processos do sujeito, para, tal como ele, ter um estatuto de objeto da análise metapsicológica e de uma expressão singular na sua relação com o sujeito. Nosso trabalho será o de circunscrever metapsicologicamente essa interação entre sujeito e instituição de maneira que ela possa evidenciar possíveis expressões sintomáticas nos casos atendidos nas mais diversas instituições. Sobre essa tarefa a ser realizada durante o trabalho, orientamo-nos a partir das seguintes considerações de Endo (2001, p.126) sobre o método analítico:

O método analítico trabalha pela via de um procedimento denominado, desde cedo, por Freud, de construção. Este método supõe que será o recém-construído o evento próprio ao trabalho de uma análise; portanto aquilo que acabou de nascer e não tem, na experiência do sujeito, nenhum análogo. [...]. A analogia na psicanálise, creio, faz parte da lógica do sintoma e não da lógica do método; sendo, entretanto, o método que evidenciará esta lógica, invisível a olho nu. [Endo, 2001, p. 126]

Em síntese, nossa tarefa será a de construir, nessa atuação do psicanalista no interior das instituições, o evento próprio a ser analisado a partir da metapsicologia, que nos permita, tal como podemos fazer na clínica em relação ao sujeito, enxergar nessa atuação o que há de sintomático, de repetição. Comecemos então a construir:

Os atendimentos psicológicos realizados em instituições como hospitais, escolas, universidades e presídios, entre outros, já são práticas difundidas na sociedade e apresentam condições e limitações de enquadramento muito diferentes das que trabalhamos no enquadre clássico dos consultórios. Muitas dessas limitações são concretas tais como restrição de tempo, exigência de resultados, presença de intermediários para o pagamento do trabalho, falta de controle sobre o espaço do atendimento ou mesmo inexistência de lugar específico para essa função, entre outras. Cada uma dessas limitações merece um cuidado especial em suas implicações para o trabalho do psicólogo e exige uma série de adaptações em sua prática cotidiana. O conjunto dessas limitações, variáveis de instituição para instituição, enunciam nas entrelinhas uma dificuldade ainda maior para o trabalho do psicanalista e que podemos 
circunscrever como um evento próprio a ser analisado pela metapsicologia: uma interferência institucional no campo da transferência. O modo como a instituição é apreendida pelo sujeito e suas conseqüências para a constituição de um processo analítico, sua repercussão na manifestação da transferência e das resistências, constituem, então, o norte desta pesquisa.

Ao citarmos os exemplos das condições e limitações que afetam o atendimento psicológico nas instituições podemos criar uma falsa impressão de que o atendimento clássico, realizado nos consultórios particulares, se apresenta à parte das condições institucionais que investigaremos. Entretanto, nossas questões devem delimitar e esclarecer o recorte: nosso interesse é saber como o tratamento analítico é atravessado por elementos institucionais externos à psicanálise. Desta maneira, destacamos que não se trata de uma avaliação dos efeitos da presença ou não da instituição nos atendimentos, mas sim de uma avaliação das dimensões da instituição que se apresentam como interferência no tratamento de base psicanalítica, inclusive em suas próprias características institucionais. Sem precisarmos de uma análise profunda sobre as características de cada instituição - até porque não é de nosso interesse mergulhar numa análise institucional, ou mesmo avaliar uma instituição específica - para legitimar nosso recorte, observamos que uma diferença significativa entre o atendimento psicanalítico em consultório e o atendimento em outras instituições é a perda de sua prioridade referencial. Enquanto no consultório tanto as regras instituídas quanto as forças instituintes giram em torno do processo analítico, este, quando imerso em outra instituição, passa a concorrer com forças, interesses e funções próprias do novo contexto. Até esse ponto podemos generalizar que o mesmo ocorreria para qualquer psicoterapia que deixe seu espaço de ação privilegiado. No entanto, o psicanalista enfrenta, nesse deslocamento, um problema que talvez seja só seu: o conflito entre a necessidade de flexibilidade inerente à análise e a rigidez demandada pelas funções e hierarquias institucionais. A análise não é necessariamente uma psicoterapia, um tratamento ou uma análise de caráter, mesmo que possa ser tudo isso. 
Ao ocupar um lugar na instituição, o psicanalista passa a responder não só às demandas dos sujeitos que irá atender, mas também à demanda institucional referente ao que se espera de sua função (seja esta a cura, a adaptação social, ou qualquer outra). Uma questão que se apresenta frente a esse conflito é, então, saber se a análise resistiria ao contexto institucional, ou se desconfiguraria numa outra prática, com a psicanálise não podendo mais ser identificada na situação, mas apenas nas motivações da prática do psicanalista.

A imersão em um contexto institucional estranho, além do conflito de demandas, apresenta também reflexos em relação à abertura do sujeito aos atendimentos e ao seu enquadramento. As causas mais profundas, inconscientes, que fazem uma pessoa se engajar em um tratamento psicanalítico numa instituição não psicanalítica, a princípio, não são muito diferentes das que a vinculariam a um atendimento em um consultório psicanalítico. Porém, podemos nos remeter à experiência cotidiana para constatar que alguém que procura uma universidade ou um hospital para tratar de seus problemas, ou que é obrigado a passar por atendimento em um presídio ou hospital psiquiátrico, não vive esta vinculação da mesma maneira daquele que procura diretamente o psicanalista devido à sua especialidade. As instituições carregam consigo uma série de representações e funções que se colam ao profissional que se vai consultar, o que implica, antes mesmo de qualquer contato entre a pessoa e o profissional, uma complexa relação preestabelecida.

Outro elemento a ser destacado do contexto que escolhemos analisar é o atravessamento imposto pela presença de outros no enquadramento. No consultório, toda interação real se dá apenas entre analista e analisando; os outros se tornam presentes apenas por via do discurso. Um serviço de atendimento implica uma hierarquia, uma estrutura, composta por outros profissionais, com as quais tanto analista quanto analisando se relacionam de modo real ou fantasmático para que se estabeleça o atendimento. Na instituição de que outros fazem parte nem todas as regras são negociadas na relação analista-analisando; 
além disso, há ainda a sombra de uma instância maior - à qual posso recorrer, mas que também pode, diretamente, me prejudicar. Encontramos ilustrações mais concretas desse fato quando vemos um serviço público que entra em greve e paralisa os atendimentos, ou quando um paciente reclama do atendimento que recebeu para a administração de um serviço. Dentro dessas condições, encontramos outras questões relevantes sobre a qual se debruçará nossa pesquisa: como a transferência se configura nesse contexto? Quais recursos técnicos em relação ao trabalho e à interpretação da transferência podem ser operados nestas condições?

Para realizar esse estudo sobre as condições clínico-teóricas que ora possibilitam, ora não o exercício da prática psicanalítica nas instituições, nosso trabalho passará, então, por dois momentos: a) uma investigação sobre as condições da transferência na instituição e seus desdobramentos tanto para o paciente quanto para o terapeuta; b) uma investigação sobre a influência das condições institucionais na dinâmica inconsciente instaurada entre terapeuta e paciente. Por último, nos propusemos a fazer um ensaio, com o auxílio de duas vinhetas clínicas, sobre como a investigação conceitual que realizamos poderia aparecer em casos singulares de atendimentos em instituições, oferecendo alternativas de compreensão para casos em que de alguma forma a condição institucional ofereceu resistência ao processo.

Nosso objetivo é que esse trabalho organize elementos que permitam compreender melhor as relações entre psicólogo, paciente e situação institucional nos atendimentos clínicos realizados no interior de instituições. Nosso interesse mais amplo é poder contribuir para a reflexão e qualidade dos atendimentos realizados em âmbito institucional, que, dada a realidade do país, torna-se muitas vezes a única maneira de muitos brasileiros terem acesso à atenção psicológica. 


\title{
2. A situação analítica institucional: um estudo da
}

\section{transferência.}

Nosso trabalho começa diretamente pelo estudo do objeto de nossa pesquisa, a situação analítica. Pretendemos aqui traçar alguns de seus limites e contornos para, frente aos elementos de tensão colocados por um contexto estranho, encontrar as possibilidades de inserção da dimensão institucional. Para cumprirmos esse intuito, um conceito-chave sobre o qual nossa investigação deverá se lançar é o da transferência. Na introdução, afirmamos que nosso principal interesse é a esfera inconsciente dos fenômenos, e é justamente por via da transferência que inconsciente e situação analítica se encontram para formar um campo comum. Para delimitarmos os reflexos inconscientes que uma dimensão institucional, externa à prática psicanalítica strictu-sensu, pode gerar, torna-se importante, então, antes de tudo, que a transferência seja foco de nossa investigação.

Sobre a manifestação da transferência, dentro do contexto que nos propomos a estudar, encontramos algumas considerações já em Freud (1912 / 1976, p.41):

\begin{abstract}
A manifestação de uma transferência negativa é, na realidade, acontecimento muito comum nas instituições. Assim que um paciente cai sob o domínio da transferência negativa, ele deixa a instituição em estado inalterado ou agravado. A transferência erótica não possui efeito tão inibidor nas instituições, visto que nestas, tal como acontece na vida comum, ela é encoberta ao invés de revelada. Mas se manifesta muito claramente como resistência ao restabelecimento, não, é verdade, por levar o paciente a sair da instituição - pelo contrário, retém-no aí - mas por mantê-lo a certa distância da vida. Pois, do ponto de vista do restabelecimento, é completamente indiferente que o paciente supere essa ou aquela ansiedade ou inibição na instituição; o que importa é que ele fique livre dela também na vida real [grifo nosso].
\end{abstract}

Apesar de não explorar o tema no decorrer do artigo, até porque não se tratava do seu objetivo, Freud lança a perspectiva de que os fenômenos transferenciais entre o paciente e o 
médico ocorrem de maneira distinta quando inseridos numa instituição. ${ }^{4}$ Não se trata de uma distinção qualquer: trata-se do favorecimento da resistência do paciente, seja pelo surgimento de transferências negativas, que o fazem abandonar o tratamento, seja pelo encobrimento de transferências eróticas, que o mantêm perpetuamente na instituição. Essa diferença nos aponta um caminho - a relação entre transferência e resistência, e a aparição de transferências positivas e negativas incitadas por um contexto diferenciado -, mas ainda se restringem a mera descrição da experiência.

Em outro texto, quando discute sobre até que ponto se deve buscar o apoio intelectual do paciente como auxílio ao tratamento, o autor faz nova alusão à condição especial da situação institucional (FREUD, 1912a/1976, p.59):

É errado determinar tarefas ao paciente, tais como coligir suas lembranças ou pensar sobre um período específico de sua vida. Pelo contrário, ele tem de aprender, acima de tudo [...] que atividades mentais [...] não solucionam nenhum dos enigmas de uma neurose [...]. Por esta razão, não gosto de utilizar-me de escritos analíticos como assistência a meus pacientes; exijo que aprendam por experiência pessoal e asseguro-lhes que adquirirão conhecimento mais amplo e valioso do que toda a literatura da psicanálise poderia transmitir-lhes. Todavia, reconheço que, em condições institucionais, pode ser de grande vantagem empregar a leitura como preparação para pacientes em análise e como meio de criar uma atmosfera de influência [grifo nosso].

Podemos destacar outro aspecto diferenciado do tratamento em instituições: as condições de influência do analista. Entretanto, mais uma vez temos elementos - a preparação para os pacientes e a atmosfera de influência - apenas para iniciar uma investigação, pois não encontramos esclarecimentos metapsicológicos, em Freud, que sustentem essa posição.

A partir dessas pistas, que nos orientam para uma análise mais profunda da transferência e da atmosfera de influência do analista, somos levados a dar um passo atrás, para nos debruçarmos sobre o que o conceito de transferência pode nos oferecer. Esperamos,

\footnotetext{
${ }^{4}$ Freud não define instituição para tecer esses comentários. Apesar disso, podemos depreender do contexto que, naquele momento, ele se refere à instituição que estabelecemos como referência para nosso trabalho.
} 
assim, encontrar sustentação metapsicológica tanto para as observações de Freud quanto para nossas próprias observações no campo institucional do atendimento analítico.

\subsection{O CONCEITO DE TRANSFERÊNCIA}

A exploração sobre as possibilidades oferecidas por esse conceito é tarefa bastante árdua, pois se trata de um dos pilares do método psicanalítico sobre o qual muito já se falou. Desse modo, não pretendemos fazer um estudo exaustivo do tema, que consumiria todo nosso trabalho, mas buscaremos reunir um certo número de elementos que nos auxiliarão a compreender as nuanças do institucional na transferência.

Comecemos por desenvolver o conceito que teremos por referência. As primeiras formulações de Freud que dizem respeito ao fenômeno da transferência ocorrem ainda no período da técnica catártica, a partir de sua percepção de que afetos não provocados pelo médico eram transferidos para sua figura e se constituíam como resistência ao tratamento. Fruto do recalcamento, no passado, de um desejo proibido, tratar-se-ia de uma falsa conexão entre esses afetos (e as defesas conseqüentemente despertadas) e a figura atual do médico (FREUD, 1893-5/1974; LAGACHE, 1951/1990).

Anos mais tarde, num dos artigos dedicados à técnica, Freud (1912a/1976, p. 34) evidencia o caráter libidinal da transferência:

Assim, é perfeitamente normal e inteligível que a catexia libidinal de alguém que se acha parcialmente insatisfeito, uma catexia que se acha pronta por antecipação, dirija-se também para a figura do médico. Decorre de nossa hipótese primitiva que esta catexia recorrerá a protótipos, ligar-se-á a um dos clichês estereotípicos que se acham presentes no indivíduo; ou, para colocar a situação de outra maneira, a catexia incluirá o médico numa das "séries" psíquicas que o paciente já formou.

Esse transbordamento de energia libidinal insatisfeita, que não faria distinção de objeto, nos lança a uma compreensão do fenômeno em sua condição econômica. A 
transferência, então, seria resultado de investimentos libidinais insatisfeitos que encontrariam vazão em “protótipos”, “clichês estereotípicos”. O que nos interessa nessa formulação é a possibilidade de “protótipos” e “clichês estereotípicos” (que podem ter origem na cadeia de sentidos oferecidos pela dimensão institucional) se inserirem na "série psíquica” do sujeito. Observamos nessa descrição um processo que faz um médico tornar-se meu objeto de investimento libidinal. Um maior desenvolvimento a respeito dessa questão é realizado por Ferenczi (1909/1991, p.78-79):

A transferência apresenta-se como um mecanismo psíquico característico da neurose em geral, que se manifesta em todas as circunstâncias da vida e abrange a maior parte das manifestações mórbidas. [...] Se os neuróticos pululam nos movimentos de tendência humanitária ou reformista, entre os pregadores da abstinência (vegetarianos, antialcoólicos, abolicionistas), nas organizações e seitas religiosas, nas conspirações pró ou contra a ordem política, religiosa ou moral, isso se explica pelo deslocamento, nos neuróticos, das tendências egoístas (agressivas e eróticas) recalcadas, censuradas, do inconsciente para um plano onde elas podem ser vividas sem culpa. [...] a transferência é apenas um caso particular da tendência geral dos neuróticos para o deslocamento [grifo nosso].

Nesse artigo, Ferenczi dá grande relevância ao mecanismo da transferência e passa a entendê-la como uma manifestação que não se restringe à situação analítica. $O$ autor considera que são os mesmos mecanismos psíquicos que estão em jogo quando o neurótico atua na transferência ou quando ele se engaja em algum grupo ideológico. Tratar-se-ia em ambos os casos do deslocamento de tendências recalcadas, inconscientes, para uma outra esfera, “onde elas podem ser vividas sem culpa”. Para trabalhar nesse campo, Ferenczi nos oferece o conceito de introjeção.

O termo "transferência" criado por Freud deve ser conservado para designar as introjeções que se manifestam no decorrer da análise e que visam a pessoa do médico, em virtude de sua excepcional importância prática. O termo "introjeção" convém a todos os outros casos que implicam o mesmo mecanismo [FERENCZI, 1909/1991, p.88]. 
Temos aqui uma linha de pensamento que pode nos trazer algum rendimento, pela convergência promovida entre situação analítica e uma dimensão institucional (grupos ideológicos), que é de nosso interesse. Sobre o funcionamento desse mecanismo,

O neurótico procura incluir em sua esfera de interesses uma parte tão grande quanto possível do mundo externo, para fazê-lo objeto de fantasias conscientes ou inconscientes. [...] O neurótico está em perpétua busca de objetos de identificação, de transferência; isso significa que atrai tudo o que pode para a sua esfera de interesses, introjeta-os. [...] Os objetos de amor são introjetados: são mentalmente integrados ao ego [...]. Nessas condições, a obediência deixa de ser um desprazer; o rapaz sente inclusive satisfação diante de manifestações de obediência paterna, dado que em fantasias apodera-se desta potência e, portanto, está obedecendo somente a si mesmo quando se dobra à vontade paterna [FERENCZI, 1909/1991, p.84-101].

Em 1912, sobre a introjeção, o autor afirma:

Em última análise, o homem só pode amar-se a si mesmo e a mais ninguém; amar a outrem equivale a integrar este outrem no seu próprio ego [...] o mecanismo dinâmico de todo amor objetal e de toda a transferência para um objeto é uma extensão do ego, uma introjeção [FERENCZI, 1912/1991, p.181182].

Retomando as citações, vemos Ferenczi entender a introjeção como uma extensão do ego, uma expansão do intrapsíquico que converte os objetos em ego para aplacar conflitos. O intrapsíquico apropria-se do outro, do extra psíquico. Na medida em que a instituição pode servir aos mecanismos de transferência, tal qual o analista, concluímos que poderia se desenvolver também nela uma neurose de transferência. Chegamos aqui a uma primeira formulação de interpenetração entre inconsciente e institucional, porém mediante um aniquilamento deste em sua complexidade: reduzido primeiramente a objeto indiscriminado de realização libidinal, ao ser posteriormente introjetado perde também seu estatuto de objeto.

A partir do que elaboramos até o momento, podemos distinguir dois aspectos da transferência: a) temporal, em que ela permite que uma experiência recalcada provavelmente relacionada aos complexos parentais - se atualize frente aos objetos que lhe 
estão atualmente à disposição; b) econômica, em que o processo só ocorre a partir da existência de uma suficiente quantidade de afetos insatisfeitos na direção dos objetos à disposição. Conseguimos também uma primeira formulação sobre a interação entre dimensão institucional e inconsciente, porém encontramos nela o problema do aniquilamento da dimensão institucional através da apropriação pelo ego. Seria possível uma outra relação? Continuemos a ampliar nosso conceito a fim de construir outras possibilidades. No Congresso de Marienbad, Glover ${ }^{5}$ (1937, apud LAGACHE, 1951/1990, p.58-9) fala sobre a transferência:

Uma concepção adequada da transferência deve refletir a totalidade do desenvolvimento do indivíduo. O paciente, é verdade, desloca ou transfere massivamente, mas desloca para o analista não só os afetos ou idéias, mas tudo o que já aprendeu ou esqueceu em todo o seu desenvolvimento.

A concepção de Glover situa a transferência no campo mais abrangente das relações humanas e a reposiciona frente à questão do que se transfere: apesar de podermos nos prender a alguns elementos mais preponderantes que nos interessem (como os afetos), o fenômeno compreende um deslocamento muito mais integral do sujeito na relação. Dessa maneira, não somente os afetos recalcados, mas todo um funcionamento antigo do sistema psíquico seria deslocado na transferência. Essa concepção, na mesma medida em que amplia nosso campo de análise para o funcionamento integral do sujeito, enfatiza também uma dificuldade: se não devemos mais nos prender à análise dos afetos, como discriminar as atitudes que seriam derivadas de transferência daquelas despertadas pelas condições atuais? Uma vez que essas condições também despertam funcionamentos antigos, tudo então seria transferência?

Dentro dessa noção mais integral da transferência, Lagache (1951/1990) discriminou alguns elementos, tomados como reais na relação analista-analisando, que nos ajudariam a

\footnotetext{
${ }^{5}$ Glover, E. Symposium on the theory of the therapeutic results of psycho-analysis: Glover, E., Fenichel, O., Strachey, J., Bergler, E., Nunberg, H., e Bibring, E. In: Intern. J. Psychoanal., 1937, 18, p. 125-195.
} 
identificar o quanto as reações do sujeito responderiam a uma condição atual: hábitos culturais, condutas ajustadas à situação (por exemplo, o emprego racional do tratamento em direção à cura), resistência a intervenções perturbadoras, e (esse um pouco mais vago) a originalidade e o valor irredutível da situação analítica. Para Lagache, a discussão girava em torno da questão da realidade. Partindo desse índice, o autor propõe uma diferenciação entre a transferência desenvolvida por Glover e aquela presente na análise como neurose de transferência.

\begin{abstract}
A transferência, em sentido amplo, é a aplicação à situação analítica de hábitos aprendidos anteriormente; esses hábitos podem estar ou não ajustados à situação real e presente; é praticamente difícil e teoricamente impossível demonstrar a experiência de uma relação interpessoal sui generis que não faça uso de nenhum hábito anterior. A neurose de transferência implica, na relação analítica, as condutas que usam hábitos e atitudes inadequados para a situação real e presente, atualização ecumênica dos conflitos inconscientes do paciente [LAGACHE, 1951/1990, p.112].
\end{abstract}

Trata-se de uma definição importante, por sintetizar uma posição que pode se depreender da obra de Freud, principalmente em relação à dimensão temporal do conceito, e por propor uma divisão mais clara entre a transferência enquanto fenômeno humano e a transferência que teríamos de trabalhar na situação analítica. Entretanto, essa definição da transferência como hábito, sendo a neurose de transferência um hábito não adaptado, parecenos insuficiente para descrever a intensidade com que esse fenômeno se manifesta na clínica, bem como sua relação com os processos inconscientes. Além disso, como aponta Laplanche (1993), não é tão simples - pelo que a situação analítica propõe - julgar o quanto uma atitude é adequada ou não dentro da análise (afinal, se nosso trabalho é fazer emergir o inconsciente, como determinar parâmetros de adaptabilidade para sua aparição?).

Para complementar nosso conceito, buscaremos então algumas idéias de Laplanche (1993) em relação ao funcionamento da situação analítica. O autor sustenta a hipótese de que a situação analítica pode ser tomada como uma formação inconsciente, como um lugar privilegiado de manifestação deste, tal como o sonho, as fantasias, o lapso, o chiste e o ato 
falho. No caso da situação analítica, é justamente a manifestação da transferência que nos permite considerá-la uma formação inconsciente. No entanto, o que a diferencia das demais formações inconscientes é o fato daquela ser uma “formação artificial”, em que o inconsciente não se manifesta espontaneamente, mas é incitado a se manifestar pelas condições oferecidas pelo setting analítico. Além disso, trata-se de uma formação datada historicamente e construída por uma série de atos.

Para compreender o funcionamento da situação analítica, Laplanche a compara com o funcionamento do sonho. Alguns elementos importantes dessa comparação interessam à composição de nosso conceito. O sonho, para além de sua interpretação, é lugar de realização do desejo. Mais que isso, é também lugar de fabricação do desejo, pelo rearranjo das pulsões. Pode-se pensar também a cena analítica nesses termos. “A conaturalidade entre sonho e tratamento se faria no nível energético e processual, no sentido de que sonho e tratamento seriam dois crisóis maiores do desejo, do Wunsch sexual” (LAPLANCHE, 1993, p.165). Isso implica entender que a transferência, tal como o sonho, para além de sua interpretação, é realização e produção de desejo. Trata-se de uma importante reconfiguração do conceito: o referencial temporal, que nos levava a uma discriminação da transferência por seu grau de adaptabilidade, perde em muito sua relevância para entendermos o fenômeno analítico. Ao passarmos a entender esse processo como lugar de realização do desejo e rearranjo das pulsões, é a dimensão inconsciente que se evidencia, é a partir do interior do sujeito que se delimita o que é ou não transferência.

Por conseqüência, rompemos também com a oposição entre realidade e fantasia. Ao abandonarmos o referencial externo ao sujeito e o critério de adaptabilidade para definir a transferência, deixa também de fazer sentido descrevê-la como uma defasagem entre fantasia e realidade. Para lidarmos com a distinção entre as reações transferenciais e as reações nãotransferenciais somos levados a procurar outras idéias: 
Qual é, pois, essa defasagem, esse desvio entre, por um lado, a cena da vida "real" e, por outro, a do sonho, a do tratamento, e talvez também a da obra, a Dichtung? Todo o nosso esforço é mostrar que a oposição real-fictício explica muito mal isso, a menos que se imponha, a esses dois termos, uma deriva. Para dizer em uma palavra: esse desvio não é senão o do não sexual ao sexual, o que nos leva a pressentir que a própria "transferência", no sentido corrente do termo, deveria ser relacionada, como na sua origem, a essa defasagem primeira $e$ fundadora [LAPLANCHE, 1993, p.200].

Um conceito que emerge para dar conta dessa distinção é o de realidade psíquica. A realidade psíquica se instaura por meio do recalcamento originário, é o núcleo duro que resulta dessa “defasagem primeira e fundadora”. Apesar de podermos tomá-la como psíquica, tem status de realidade por ser, no interior do sujeito, alheio a ele. A transferência se configura nesse quadro como o processo em que elementos dessa realidade psíquica podem emergir como reações do sujeito; identificar o quanto são reais ou imaginários os elementos a que responde o sujeito passa a se vincular e a saber como se constitui essa realidade psíquica. O problema, recolocado dessa forma, torna uma discussão sobre o estatuto da realidade psíquica bastante relevante para entender qualquer transferência. Por enquanto, basta reconhecê-la como fonte do material transferencial. Deixaremos uma discussão mais pormenorizada sobre a constituição da realidade psíquica para o próximo capítulo.

Outro elemento importante que a comparação com o sonho nos oferece é a condição de isolamento. O sonho repousa no sono e tem como seu guardião o ego; este cumpre a importante função de permitir que o sonho aconteça, processando os estímulos que surgem durante o sono de maneira que eles não nos despertem. Encontramos uma situação similar na análise. A transferência repousa no isolamento do ambiente analítico e tem como guardiões o enquadramento do setting e o analista. É pelo enquadramento claro e pela ação do analista que o analisando pode ter assegurado o isolamento da situação analítica. Durante o processo, acontecimentos da vida forçam os limites do setting, impõem-se como demandas mais urgentes do que a análise. Cabe ao analista processar esses acontecimentos e, tal como faz o 
ego aos estímulos que ocorrem durante o sono, fazer deles material a ser trabalhado dentro da dimensão analítica e transferencial.

O último elemento que gostaríamos de destacar na proposição de Laplanche (1993) se refere a como o desejo se manifesta no sonho e na transferência. Tal como o sonho, que utiliza os restos diurnos da realidade externa para construir suas cenas, a transferência faz uso de todos os elementos que o ambiente analítico oferece (inclusive o próprio corpo do analista) para se constituir, configurando-se entre as demandas de sua realidade psíquica e os elementos oferecidos pela realidade externa.

Temos agora um conceito mais complexo de transferência. Diante de nossa primeira análise, a dimensão temporal, que associava a transferência a uma reedição e atualização de uma experiência passada, tem sua relevância diminuída. O aspecto econômico relacionado com a dinâmica pulsional, bem como os processos inconscientes envolvidos no processo de introjeção, por outro lado, tornam-se mais importantes, pois a dimensão intrapsíquica passa a ser nossa principal referência. Por transferência, portanto, consideraremos que se trata de uma formação inconsciente passível de produção, mobilizada tanto por uma condição interna quanto por uma condição externa ao sujeito. Para o sujeito, constitui-se como esfera de realização e rearranjo de conflitos pulsionais e demais demandas da realidade psíquica. Para o analista, constitui-se como manifestação privilegiada de uma realidade psíquica para a qual ele é chamado a tomar parte, no preciso momento da transferência. Quanto a ser passível de produção, referimo-nos à possibilidade desse fenômeno, em sua relação com o ambiente, poder ser incitado por condições externas ao sujeito, situação que encontramos, por exemplo, na análise. Temos agora uma visão mais abrangente do conceito de transferência, que abre espaço para três outras inserções do institucional: a) como cena continente e produtora do fenômeno transferencial, incitando a manifestação das pulsões e isolando-as do resto do mundo; b) como matriz dos sentidos que permitem às pulsões tornarem-se desejos, que deixa 
a realidade psíquica manifestar-se aos nossos olhos; c) como elemento constitutivo da realidade psíquica, apoiando a própria possibilidade de condição subjetiva (dedicaremos o próximo capítulo a explorar essa possibilidade).

Para desenvolvermos a primeira e a segunda dessas novas possibilidades, retomemos nossa espiral em torno da transferência e para cada uma delas abordemos alguns aspectos específicos desse processo: a) a dinâmica das pulsões e o ambiente propiciador; b) o papel ou papéis que o analista ocupa.

\subsection{TRANSFERÊNCIA POSITIVA E TRANSFERÊNCIA NEGATIVA -}

\section{CONSIDERAÇÕES SOBRE A DINÂMICA PULSIONAL}

Compreender como as pulsões se apresentam no campo transferencial aponta inicialmente para um estudo da manifestação dos afetos. Em relação ao caráter afetivo, Freud (1912a/1976) distingue as transferências em negativas (de sentimentos hostis) e positivas, sendo esta divisível ainda em transferência de sentimentos amistosos/afetuosos (admissíveis à consciência) e de impulsos eróticos reprimidos (inconscientes). A partir dessas distinções, o autor demonstra que são as transferências negativas e as positivas de impulsos eróticos reprimidos as que oferecem maiores resistências ao tratamento analítico, pois coíbem o paciente em seu trabalho de cumprir a primeira regra fundamental da psicanálise. ${ }^{6}$ As transferências negativas coíbem essa regra na medida em que atacam o vínculo de confiança do paciente com o analista; as positivas de impulsos eróticos a coíbem por condicionar as falas a uma sedução, fazendo emergir sentimentos como a vergonha ou a autocensura. O que

\footnotetext{
${ }^{6}$ Essa regra estabelece ao paciente que tudo que lhe venha à cabeça deve ser comunicado sem crítica. Encontra seu paralelo, do ponto de vista do analista, na regra de atenção igualmente flutuante.
} 
essa divisão, que Freud carrega até o final de sua obra, nos oferece, é uma discussão sobre os afetos na transferência, que gira em torno da questão da resistência.

Nosso foco é uma discussão sobre os afetos, que poderá nos levar às pulsões; porém, antes, localizemos rapidamente a resistência em nosso trabalho. Esse conceito se encontra vinculado ao ideal da análise, refere-se aos obstáculos enfrentados rumo ao que poderíamos chamar de progresso analítico, e no tratamento choca-se diretamente com o trabalho do analista. A resistência opera contrariamente (resistindo) a um ideal que é do psicanalista, definindo-se, então, por um referencial “externo” (entre aspas porque podemos levar em consideração que um analisando, ou um psicanalista, pode se referir às suas próprias resistências depois de se apropriar da linguagem psicanalítica e, neste caso, essa exterioridade deve ser relativizada). Em nossa argumentação sobre a transferência, centrada nos fenômenos que têm por referência o próprio sujeito, a resistência, no momento, ocupa um papel lateral (o que será diferente, num capítulo posterior, quando discutirmos a técnica psicanalítica); por ora, o que nos interessa em relação à associação de Freud é o fato das resistências possuírem íntima ligação com as defesas do ego, e é por esse viés das resistências que poderemos seguir.

Lagache (1951/1990), sustentado por elaborações de Reich, problematiza também a questão da transferência positiva não erótica do início de análise, que em Freud é preservada como exclusiva fonte de benefícios. O autor afirma que é principalmente com uma transferência negativa que devemos contar, mesmo no início da análise. Sua aparência positiva serviria para cumprir três funções:

1. Defesa contra a transferência negativa latente.

2. Expressão da culpa e do masoquismo moral, servindo como defesa contra o ódio.

3. Aspiração narcisista a ser amado, o que, decepcionada pelo analista, se converte finalmente em hostilidade. 
A questão do positivo e do negativo torna-se complexa, pois passa a se desdobrar em duas esferas: uma manifesta e outra latente. Contaríamos, então, com a presença de uma face da transferência que aparece e outra que se oculta. Frente a essas duas faces da transferência, a latente agiria diretamente no psiquismo do sujeito, sendo de alguma forma metabolizada internamente, enquanto a manifesta já possuiria em sua composição uma certa “contribuição” das defesas psíquicas. Em relação à transferência negativa latente, Daniel Lagache (1951/1990, p.51-2) comenta:

Uma conseqüência lógica é a assimilação da transferência negativa e da resistência. É o que Reich diz ter feito no começo, designando por transferência negativa toda forma de defesa do ego; essa concepção lhe parece correta por duas razões: 1. a defesa do ego faz uso, mais cedo ou mais tarde, das pulsões de ódio preexistentes; 2. a interpretação da resistência, se partir da defesa do ego, provoca sempre ódio; mas não é correto chamar "transferência negativa" à defesa do ego: trata-se, antes, de uma reação narcísica de defesa. Do mesmo modo a "transferência narcísica" não é uma transferência negativa strictu sensu.

Um argumento que nos interessa se refere ao fato da "defesa do ego fazer uso das pulsões de ódio preexistentes”. Consideramos essa proposição interessante por criar, ao mesmo tempo, uma distinção e um elo entre as pulsões e as defesas do ego. As defesas do ego podem fazer uso das pulsões, mas não se confundem com elas. Podem assimilar-se mutuamente, mas têm origens distintas, uma distinção que Lagache sublinha ao afirmar que a transferência narcísica não é uma transferência negativa strictu sensu. Porém, só podemos conceber essa diferenciação se tomarmos a questão da hostilidade, que caracteriza a transferência negativa, não em sua manifestação externa, mas em sua latência, que remete a uma fonte não narcísica. Começamos aqui a nos aproximar do campo das pulsões.

Outro item que pode nos auxiliar nessa circunscrição do campo das pulsões na transferência é a questão do amor transferencial. Em 1915, Freud dedica um texto especialmente a essa questão (1915/1976, p.218-9):

O amor transferencial caracteriza-se por certos aspectos que lhe asseguram posição especial. Em primeiro lugar, é provocado pela situação analítica; em 
segundo, é grandemente intensificado pela resistência, que domina a situação; e, em terceiro, falta-lhe em alto grau consideração pela realidade, é menos sensato, menos interessado nas conseqüências e mais ego em sua avaliação da pessoa amada do que estamos preparados para admitir no caso do amor normal. Não devemos esquecer, contudo, que esses afastamentos da norma constituem precisamente aquilo que é essencial a respeito de estar enamorado [grifo nosso].

Da caracterização de Freud sobre o amor transferencial, o ponto que mais nos interessa é o terceiro. O fato de o amor transferencial ser “mais ego" que o amor normal, na avaliação da pessoa amada, suscita a questão de entender como se processa esse amor no interior do sujeito, e o quanto essa condição tem participação na relação analítica. Em Fédida (1988, p.47-8), encontramos auxílio para essa discussão:

\begin{abstract}
A problemática do amor se acha aqui marcada pela impossibilidade de novas totalizações, a tal ponto que quando o paciente se enamora do terapeuta não se trata de outra coisa, pode-se dizer, senão uma angina, nada mais que uma somatização - certamente uma somatização peculiar - mas é, sobretudo um medo de esfacelamento, um medo de fragmentação, que leva a totalizar o amor na pessoa do terapeuta. [...] O paciente tem necessidade da totalização do amor de transferência para se proteger contra essas ameaças interiores tão fortes e tão violentas. Ameaças que estão ligadas à multiplicidade parcial de pulsões na palavra.
\end{abstract}

Vemos emergir, em Fédida, a problemática do amor transferencial como uma tensão entre as pulsões parciais, vividas como experiência de fragmentação, e a busca por uma totalização impossível. É essa tensão que se vê produzida e intensificada pela situação analítica. A questão da somatização, que tem como referência o adulto, aponta para uma tentativa de totalização operada pelo corpo: frente à multiplicidade de excitações pré-sexuais despertadas pela análise, o corpo responde com os recursos de que dispõe - a paixão sexual pelo analista.

Em meio às discussões sobre os afetos na transferência, por meio da transferência negativa latente e do amor transferencial, encontramos aspectos pulsionais importantes presentes na transferência. Tanto os afetos hostis quanto os sexuais, aparentes ao analista na transferência, são resultados de uma tensão pulsional pela qual passa o sujeito, e podemos 
dizer que esta é a condição de existencial da transferência; essa tensão tanto mobiliza as defesas narcísicas do sujeito quanto promove um movimento em direção ao mundo, em direção à situação analítica. Reunimos agora condições para analisar diretamente a questão do conflito pulsional e localizá-lo no campo transferência.

Em 1920, Freud nos oferece, em Além do princípio do prazer, a pulsão de morte, com a qual tentaremos compor esse campo de manifestação das pulsões. A transferência da pulsão de morte se apresenta fundamentalmente sob a forma da compulsão à repetição.

No caso de uma pessoa em análise [...] a compulsão à repetição na transferência dos acontecimentos da infância evidentemente despreza o princípio de prazer sob todos os modos. O paciente comporta-se de modo puramente infantil e assim nos mostra que os traços de memória reprimidos de suas experiências primevas não se encontram presentes nele em estado de sujeição, mostrando-se elas, na verdade, em certo sentido, incapazes de obedecer ao processo secundário. Além disso, é ao fato de não se acharem sujeitas que devem sua capacidade de formar, em conjunção com os resíduos do dia anterior, uma fantasia de desejo que surge num sonho. A mesma compulsão à repetição freqüentemente se nos defronta como um obstáculo ao tratamento, quando, ao fim da análise, tentamos induzir o paciente a desligar-se completamente do médico. Pode-se supor também que, quando pessoas desfamiliarizadas com a análise sentem um medo obscuro, um temor de despertar algo que, segundo pensam, é melhor deixar adormecido, aquilo de que no fundo têm medo, é do surgimento dessa compulsão com sua sugestão de posse por algum poder “demoníaco” [FREUD, 1920/1976, p.53, grifo nosso].

Diferentemente da questão do amor, explorada muito mais na esfera técnica, a compulsão à repetição leva Freud à problemática pulsional. É a pulsão de morte, “poder demoníaco” que “despreza o princípio do prazer sob todos os modos”, a energia que se apresenta na compulsão à repetição. Esta, no entanto, é manifestação em ato, e não pode ser confundida com a dinâmica própria da pulsão. A pulsão de morte nos apresenta, face à transferência, as experiências primevas “incapazes de obedecer ao processo secundário”. Já havíamos defendido antes, em nosso conceito de transferência, que esta se institui muito mais por uma realização em si do que como um meio de busca por uma interpretação. É por sua essência estar vinculada à natureza das pulsões, e em especial à pulsão de morte, que reafirmamos essa posição. Porém, se conseguimos defender que a interpretação é efeito 
secundário à manifestação da transferência e, sendo assim, não é o que, em si, mobiliza sua manifestação, nos resta buscar por qual via a situação analítica propicia essa efervescência pulsional. Havíamos considerado, em nossa exploração sobre os afetos, que a transferência se localizaria frente a uma condição de conflito entre as pulsões e os recursos do ego. Voltemos a buscar auxílio em Fédida (1988, p.47-8) para construirmos nossa posição frente a essas questões de amor e morte:

Gostaria de acrescentar que na posição analítica a síntese não é possível. Na verdade não há dialética. Há amor. No amor há pulsões parciais, há sempre o amor mais a morte, o amor mais o ódio, há sempre o amor mais o negativo. [...] O problema, assim colocado, é preciso perceber o que Freud não percebeu aqui, isto é, enamorar-se do terapeuta [...] não é simplesmente resistência. É procurar uma situação de dominação, porque na evolução pessoal o processo analítico começou a se abrir: o verdadeiro encontro com as angústias de morte arcaicas, o terror de um aniquilamento. Nessas condições, o paciente se agarra ao terapeuta esperando fazer uma unidade com ele.

Temos com Fédida uma retomada das questões levantadas pelo amor transferencial acrescidas do que Freud pôde desenvolver no texto Além do princípio do prazer. Amor e morte se encontram na transferência frente ao terror das "angústias de morte arcaicas” suscitadas pela emergência das pulsões parciais. O processo analítico, trabalhando no sentido contrário das defesas do ego que se apresentam como resistência, desvela essa dinâmica pulsional primitiva. É nesse ponto que localizamos a constituição da neurose de transferência, possibilidade radical de realização, na transferência, pela emergência das pulsões recalcadas.

Em todo esse movimento não é o amor o que é importante, mas a transferência, e quando a transferência é importante, é a morte. [...] Ora, a morte está no âmago de toda pulsão. E é contra isso que se choca o psicanalista [FÉDIDA, 1988, p.40-1].

A morte, no âmago de toda pulsão, é o que se choca contra o ego do analisando na cena transferencial e, desta forma, convoca também o analista, em suas próprias pulsões arcaicas, para dentro da cena. Esse é o choque. Frente à sensação de fragmentação imposta pela emergência de pulsões arcaicas não satisfeitas, a tentativa de unidade é sedutora, pois 
oferece uma falsa promessa de apaziguamento. Sedutora, pois remete a um estado originário em que não havia angústia. Falsa, porque essa unidade, não sendo possível internamente, também não o é na transferência. Alcançamos aqui a problemática do conflito pulsional na transferência sintetizada na seguinte fórmula: pelas pulsões parciais arcaicas, pela morte no interior das pulsões, a transferência se estabelece como possibilidade de produção de sentido, de realização pulsional; essa realização, em reação à angústia de fragmentação incitada pelo processo analítico, pode se apresentar como tentativa de recomposição de uma unidade do ego (manifestação sexual) ou pode se apresentar no caminho da fragmentação total (manifestação hostil), neste caso levada a cabo pela projeção dos impulsos e ruptura com o analista. O que o analista tem a seu favor nesta dinâmica são as pulsões de vida, que diferente de se manifestarem como sentimentos amistosos em relação ao analista, realizam-se pelo desejo de “cura” do analisando, pelo desejo de sustentar a análise.

Voltemos a nos localizar frente à discussão sobre o institucional. Percorremos esse caminho ao encontro de uma verificação da possibilidade de inserção da instituição como continente das tensões pulsionais. A continência dessas tensões no sujeito, pelo que trabalhamos até aqui, se dá pelo ego, com o auxílio de seus recursos defensivos. Ao retomarmos as observações de Freud (1912a/1976) sobre a transferência nas instituições, encontramos as seguintes observações: “a manifestação de uma transferência negativa é, na realidade, acontecimento muito comum nas instituições” e “a transferência erótica não possui efeito tão inibidor nas instituições, visto que nestas, tal como acontece na vida comum, ela é encoberta ao invés de revelada”. Temos agora condições de trabalhar essas afirmações e com isso começar a localizar o institucional em seu estatuto continente do conflito pulsional em questão na transferência. Se a transferência negativa é comum nas instituições e se podemos associá-la às pulsões parciais realizadas como hostilidade, podemos considerar que nas instituições encontramos um facilitador para essa via de realização da pulsão. Da mesma 
maneira, se a transferência erótica não é tão inibidora na instituição, por ser encoberta, e se podemos considerá-la como realização sexual frente à angústia de fragmentação, é porque também encontramos uma condição facilitadora para o encobrimento desta motivação. Se considerarmos que, por último, ao tratarmos da questão em torno das pulsões, isolamos a possibilidade de uma influência direta da instituição em sua dinâmica - as pulsões não são atribuídas ao sujeito pelo meio - e que a manifestação da transferência na situação analítica tem como contraponto uma transferência pulsional latente, vivida pelo ego e marcada por suas defesas na direção de uma reação hostil, afetuosa, sexual ou qualquer outra, somos levados a concluir que os dois processos descritos acima passam por um mesmo caminho: uma ampliação dos recursos defensivos do ego quando inserido em contexto institucional. Ao observarmos que algumas manifestações são mais favorecidas nas instituições, verificamos que a função continente do ego frente às pulsões parciais do id é fortalecida pela vinculação entre ego e instituição. Entretanto, frente a esse fortalecimento do ego e suas defesas, para cumprir sua função de continência dos conflitos pulsionais, há ainda uma distinção que precisamos esclarecer: aquela entre as defesas do ego atuais e as primitivas, também passíveis de transferência.

Afirmada a problemática das pulsões arcaicas e da marca operada pelas defesas do ego na manifestação das pulsões, somos levados a considerar um outro elemento que ainda não havíamos abordado: a transferência das defesas primitivas do ego. Para tratar do assunto, Anna Freud (1946/1977) divide a transferência em transferência de impulsos libidinais e transferência de defesa. Lagache (1951/1990, p.56-7) resume essa diferença da seguinte forma:

A transferência de impulsos libidinais suscita a vergonha e a confusão do paciente, que na maioria dos casos dá uma colaboração solícita, porque o impulso transferido age nele como um corpo estranho; sua remissão ao passado lhe facilita a continuação da análise. $\mathbf{O}$ automatismo de repetição envolve não só as antigas pulsões do id, mas também as antigas medidas de defesa contra os instintos; as pulsões são transferidas com as deformações que 
ficaram marcadas desde a infância; nos casos extremos, só a defesa aparece; a boa técnica consiste em estudar então a defesa, ou seja, mais o ego do que o id, com a seguinte dificuldade: neste caso, o paciente não tem a sensação de possuir um corpo estranho dentro dele; não se pode contar com a colaboração dele [grifo nosso].

Anna Freud (1946/1977) explora a idéia de que não só pulsões primitivas estão envolvidas na transferência, mas defesas primitivas também. O retorno das pulsões recalcadas traz consigo as deformações operadas pelas defesas primitivas do ego, e quanto maior essa deformação, quanto mais o ego se reconhecer nesta pulsão, menor a possibilidade de contar com as defesas atuais. O funcionamento dessa "transferência de defesa” nos impõe mais um ponto de complexidade na situação transferencial: a transferência dessas "pulsões deformadas”, que no limite se apresentam como a encarnação das próprias defesas, é egossintônica, ou seja, incorpora-se ao ego por ter dele uma marca indelével. Ilustrativamente, temos nesse quadro que a pulsão não é identificada pelo sujeito como um afeto angustiante que o invade, mas sim como uma angústia existencial de ser si mesmo. Não se trata daquilo que sinto, mas daquilo que sou. Além disso, por sua raiz originária e por sua aderência às pulsões, essa defesa primitiva se torna um agente equivalente às pulsões parciais do id que circulam pelo psiquismo. Portanto, devemos compreendê-las como mais uma força dessa tensão pulsional em jogo na transferência.

A questão com que nos deparamos é se a associação entre ego e instituição pode ser continente também em relação às “transferências de defesa”. Colocamos antes que a instituição se associa às defesas atuais do ego para dar continência aos conflitos pulsionais. Na transferência de defesa, encontramos o fator egossintônico, que faz com que o ego se reconheça na pulsão recalcada e não opere novas defesas. Resta-nos saber, então, o quanto a associação entre ego e instituição preserva um nível de diferenciação entre ambos que permita, no caso da transferência de defesa, que essa função continente possa ser cumprida pela instituição, mesmo quando o ego não reconhece essa necessidade. Se ao considerarmos as pulsões parciais do id chegamos a uma inserção do institucional, em relação à análise, 
associada às resistências (pela ampliação dos recursos defensivos do ego), no caso de uma continência equivalente da transferência de defesa, existe a possibilidade do institucional cumprir uma função analítica: através da continência de suas defesas primitivas, possibilidade de que também elas se choquem com as pulsões do id e encontrem nova resolução. Porém, trata-se ainda de uma hipótese, que leva em conta apenas o nível energético e pulsional. A resposta à questão extrapola a discussão do pulsional. Somos levados a verificar quais as possibilidades de associação entre analisando, analista e instituição na manifestação da transferência; nessa discussão, poderemos verificar também em que medida a natureza dessa associação envolve a produção da transferência.

Para concluir nossa discussão sobre o pulsional, retomemos que, como realização/produção do desejo, a transferência cumpre uma função que extrapola nossos interesses analíticos e se estabelece quase que fundamentalmente como caldeirão de tendências energéticas.

Não ficaremos desapontados, mas, pelo contrário, acharemos perfeitamente inteligível, se chegarmos à conclusão de que o desfecho final da luta em que nos empenhamos depende de relações quantitativas da cota de energia que podemos mobilizar no paciente, em nosso favor, comparada à soma de energia das forças que trabalham contra nós. Aqui, mais uma vez, Deus acha-se do lado dos grandes batalhões. É verdade que nem sempre conseguimos ganhar, mas, pelo menos, podemos geralmente identificar por que foi que não vencemos [FREUD, 1940/1996, p.196, grifo do autor].

\subsection{A ORGANIZAÇÃO FANTASMÁTICA E A TÓPICA DO INCONSCIENTE -}

\section{CONSIDERAÇÕES SOBRE A ESTRUTURA DA CENA TRANSFERENCIAL}

Para iniciar a investigação sobre o lugar ocupado pela instituição em relação ao ego do analisando e a função do analista na transferência, para inclusive verificar o quanto esta posição pode produzi-la, comecemos por avaliar como se estabelece a relação entre analista e 
analisando na situação analítica clássica. Na conferência XXVII, das Conferências introdutórias sobre psicanálise, Freud (1917/1976, p.516) faz as seguintes observações:

\begin{abstract}
Devo começar por esclarecer que uma transferência está presente no paciente desde o começo do tratamento e, por algum tempo, é o mais poderoso móvel de seu progresso. Dela não vemos indício algum, e com ela não temos por que nos preocupar enquanto age a favor do trabalho conjunto da análise [...]. Os sentimentos hostis revelam-se, via de regra, mais tarde do que os sentimentos afetuosos, e se ocultam atrás destes; sua presença simultânea apresenta um bom quadro da ambivalência emocional dominante na maioria de nossas relações íntimas com outras pessoas. Os sentimentos hostis indicam, tal qual os afetuosos, haver um vínculo afetivo, da mesma forma como o desafio, tanto como a obediência, significa dependência, embora tendo à sua frente um sinal “menos" em lugar de "mais” [grifo nosso].
\end{abstract}

Freud aponta que a condição afetiva intrínseca à transferência, mesmo em sua diversidade, orienta-nos para uma única relação vincular com o analista: a dependência. Novamente, cabe-nos diferenciar a manifestação externa de sua fonte inconsciente, que nos interessa em especial. A dependência é manifestação de uma certa organização fantasmática, que coloca toda a dinâmica pulsional que discutimos anteriormente em favor dessa possibilidade de influência do analista. Trabalhando sobre o conceito de introjeção, que já apresentamos, Ferenczi (1909/1991) encontra na sugestão e na hipnose elementos para uma melhor compreensão dessa influência. O autor considerava que, nesses métodos de tratamento, a transferência ocupava papel ainda mais determinante, pois seria fonte do poder pelo qual o médico “curaria”. Ferenczi percebe, a partir da observação da situação hipnótica, seu caráter regressivo. Ele relaciona, então, a possibilidade de onipotência do hipnotizador a uma atuação, do paciente, de sua vida instintiva infantil recalcada. Os métodos de indução hipnótica, muito próximas às posturas paterna (hipnotizador poderoso e assustador) e materna (hipnose pelo acolhimento, pelo isolamento dos estímulos e ameaças do mundo), oferecem a Ferenczi mais elementos ainda para afirmar que a origem da relação transferencial se encontra nos complexos parentais - “a raiz mais profunda da transferência, como de todo amor objetal, provém dos complexos parentais” (FERENCZI, 1909/1991, p.95-6). Desta forma, a 
transferência seguiria uma organização fantasmática ligada aos complexos parentais, e o analista se localizaria no lugar dos pais dentro dessa dinâmica. Verifiquemos algumas implicações dessa formulação.

No Esboço de psicanálise, no final da obra de Freud (1940/1996), apresentam-se alguns desdobramentos importantes. Exploraremos por partes:

Se o paciente coloca o analista no lugar do pai (ou mãe), está também lhe concedendo o poder que o superego exerce sobre o ego, visto que os pais foram, como sabemos, a origem de seu superego. O novo superego dispõe agora de uma oportunidade para uma espécie de pós-educação do neurótico; ele pode corrigir erros pelos quais os pais foram responsáveis ao educá-lo [FREUD, 1940/1996, p.190, grifo do autor].

O primeiro elemento que temos é que a influência sobre o analisando não é fruto exclusivo, ou pelo menos não direto, do investimento pulsional na transferência. Pela associação do analista com o lugar parental na transferência, este tem, por conseqüência, garantida uma associação às funções do superego. Lagache (1951/1990), acompanhando as idéias de Nunberg, destaca o aspecto de libidinização do superego pela identificação com o analista. Tendo como contexto o início do tratamento e a substituição do desejo de cura pela transferência:

\footnotetext{
O analista intervém como proteção contra o perigo. A reação é análoga à do hipnotizado e do hipnotizador: à maneira do hipnotizador, o paciente submete-se à vontade do analista na luta contra as resistências. O analista já não é assimilado somente ao ego mágico, mas também ao ego ideal. Ele é libidinizado, e libidiniza o superego. Desempenha um papel de mediador entre o superego e o id. Daí o freqüente desaparecimento dos estados de angústia mais violentos. Segundo a linguagem de Nunberg, o analista introduziu-se habilmente no ego e é do interior deste que ele exerce uma influência [LAGACHE, 1951/1990, p.48-9, grifo nosso].
}

A assimilação ao ego ideal e a libidinização do superego na transferência vêm ao encontro da questão que levantamos no tópico anterior, sobre a possibilidade de uma associação entre instituição e ego que não fosse completamente egossintônica, permitindo que também as transferências de defesa pudessem se rearranjar frente às pulsões parciais do id. 
Por meio da investigação da inserção do analista na transferência, percebemos que há essa possibilidade e que ela se dá por essa associação ao ego ideal e ao superego. Pela possibilidade das defesas primitivas se reajustarem e se realizarem, tal como as pulsões parciais do id, reduzem-se os estados de angústia mais violentos, pois a nova chance exime o ego de sua condição de angústia existencial (restam ainda as angústias próprias do conflito pulsional e deste com as tendências recalcadoras). Resta-nos saber o quanto o institucional cumpre também essas funções exercidas pelo analista, uma vez que a instituição não é um outro que pode se aderir à figura de um dos pais. Avancemos um pouco mais na investigação da situação clássica.

A possibilidade de influência descrita por Freud (1940/1996) oferece, ao analista, condições de uma atuação educativa, o que implica certos riscos ao uso dessa influência:

\begin{abstract}
A esta altura, cabe uma advertência contra o mau uso dessa nova influência. Por mais que o analista possa ficar tentado a transformar-se num professor, modelo e ideal para outras pessoas, e criar homens à sua própria imagem, não deve esquecer que essa não é a sua tarefa no relacionamento analítico, e que, na verdade, será desleal a essa tarefa se permitir-se ser levado por suas inclinações. Se o fizer, estará apenas repetindo um equívoco dos pais, que esmagaram a independência do filho através de sua influência, e estará simplesmente substituindo a primitiva dependência do paciente por uma nova [FREUD, 1940/1996, p.190].
\end{abstract}

Com a associação do analista ao superego do analisando, Freud chama a atenção para a responsabilidade do analista. Reconhece a presença de certas tendências - "transformar-se num [...] modelo e ideal para outras pessoas” - e alerta para que elas não sejam atuadas na transferência em prejuízo do analisando. O que nos parece relevante é notar que a possibilidade educativa, um dos desdobramentos do fenômeno transferencial, pode se mostrar contrária à função analítica pela repetição da relação recalcada, pela reedição da dependência primitiva. Neste caso, a transferência corre o risco de se reduzir à compulsão à repetição. Porém, nem sempre o educativo atua contrariamente à função analítica: 
Em todas as suas tentativas de melhorar e educar o paciente, o analista deve respeitar a individualidade daquele. A influência que possa legitimamente permitir-se será determinada pelo grau de inibição no desenvolvimento apresentado pelo paciente. Alguns neuróticos permaneceram tão infantis que, também na análise, só podem ser tratados como crianças [FREUD, 1940/1996, p.190].

Apesar dos riscos e problemas implicados no uso de uma influência sugestiva pelo analista, Freud dá margem para o uso dessa influência a depender do "grau de inibição apresentado no desenvolvimento”. Sua medida para esse grau de inibição é o infantil (“só podem ser tratados como crianças”). A influência educativa só não é anti-analítica quando ela própria é condição de desenvolvimento da análise. Freud se refere a uma condição de infantilidade, por parte do analisando, na qual a realização transferencial é necessária para que defesas primitivas deixem de ser as únicas defesas possíveis, de uma possibilidade da análise de operar uma educação mais primitiva do que aquela a que ele se referiu na passagem que abordamos anteriormente: uma educação como possibilidade de autonomia. Para que possamos compreender tal possibilidade de realização, tão significativa a ponto de substituir ou possibilitar uma etapa do desenvolvimento psíquico infantil, aproximemo-nos do outro ponto que nos interessa nessa exploração em torno da organização fantasmática: como a situação analítica produz a transferência.

A primeira a nos auxiliar na questão da produção da transferência é Karen Horney (1939/1959). A autora contribui para a discussão sobre a transferência, relativizando seu componente genético e vinculado às situações passadas, para destacar a participação da estrutura atual da personalidade, ou de uma perturbação desta, na transferência. Segundo Horney, é a estrutura inteira da personalidade que é solicitada, no momento em que o indivíduo se sente ou não atraído por outro e, conseqüentemente, pela análise. Frente ao ambiente de tolerância da análise e à regra de abstinência, as defesas costumeiras a que o analisando recorre não seriam efetivas e lhe seriam solicitadas as reações regressivas que ele apresenta na transferência. Destaquemos em Horney esta possibilidade da transferência ser 
promovida pelas condições do setting analítico, pela participação de necessidades atuais da personalidade, e não apenas para uma atualização.

Ida Macalpine (19507 ${ }^{7}$ apud LAGACHE, 1951/1990) se dedicou mais longamente a essa solicitação do setting analítico como um fator de produção da transferência. Dentro dessa compreensão, distinguiu três estágios pelos quais se desenvolveria a análise: a) estágio de indução à neurose de transferência: fase de adaptação ao ambiente infantil; b) estágio de regressão bem estabelecida: o analisando transfere para o analista e para a situação analítica a totalidade de seu desenvolvimento mental - nesse estágio, o analisando está bem estabelecido no ambiente infantil, mantém uma recusa das relações objetais e sofre uma contínua frustração libidinal; c) estágio de retorno à maturidade: ocorre parte na análise e parte fora dela. O principal eixo de sua argumentação é de que a análise promove um ambiente infantil, em que a atitude solicitada é a atitude regressiva, que por conseqüência culminaria na produção da transferência. O principal elemento desse ambiente infantil é a condição de autoridade ambivalente do analista, que traz resquícios do método sugestivo, o que o coloca, tal como o hipnotizador, efetivamente e não na fantasia, na mesma posição que ocupavam os pais. Encontraríamos na análise uma reprodução artificial das condições originais de realização dos complexos parentais, tal como ocorreria na situação sugestiva, porém com uma finalidade diferente - a análise em vez da influência sugestiva. O tratamento consistiria no processo de maturação dessa transferência que, com o trabalho analítico, deixaria aos poucos seu papel regressivo - e neste caso poderíamos considerar o fator educativo presente de maneira mais geral na análise.

Uma observação que fazemos sobre a argumentação de Macalpine é que ela trata de uma dimensão institucional da própria situação analítica clássica. Tratam-se de condições do ambiente analítico que todo psicanalista deve seguir, uma via instituída de acesso à

\footnotetext{
${ }^{7}$ Macalpine, I. The development of the transference. In: Psychoanal. Quart., 1950, 19, no 4, p. 501-505.
} 
transferência de complexos parentais. Não é nosso foco identificar essas inserções institucionais, porém esta nos auxilia a isolar um elemento importante. Se a transferência poderia ser produzida pela condição de acolhimento das fantasias e se tornar manifesta por elementos instituídos da psicanálise ligados à sua pré-história no método sugestivo, e se segundo Macalpine é pela maturação da transferência que ocorre o desenvolvimento analítico, é pela influência sugestiva que desvelamos a relação fantasmática que culmina na possibilidade de desenvolvimento psíquico na transferência, de amplitudes tão radicais quanto as apontadas por Freud. Estaria no que a análise se aproxima do método sugestivo, não no que se afasta, a possibilidade de educação de analisandos extremamente regredidos. Porém, se em relação à compreensão da relação fantasmática, que possibilita a influência educativa da transferência, julgamos que os elementos isolados em Macalpine contribuem para o esclarecimento de nossa questão, algo escapa a essa explicação em relação à produção transferencial. Apesar da semelhança de condições subjetivas entre o setting analítico e as relações fantasmáticas pautadas nos complexos parentais, nos resta saber como o sujeito é capaz de se apropriar dessa semelhança, que elemento dessa cena produzida realmente incita a transferência a se manifestar por evocar o inconsciente a se apresentar.

Ciente das hipóteses de Macalpine, Laplanche (1993) considera que o que produziria a transferência não seria o ambiente infantilizante (apesar de reconhecer que este a favorece), mas a posição e a atitude do analista em relação às frustrações. ${ }^{8}$ Essas frustrações permitiriam à análise a sua colocação na tangente da realidade, possibilidade de isolamento da situação analítica tal qual o sono permite ao sonho, o que propiciaria, assim, a diminuição de funções defensivas frente à metabolização dos estímulos e facilitaria à transferência emergir. A

\footnotetext{
${ }^{8}$ Na tradução de sua obra para o português, aparece “recusas”. Apesar do termo “recusa” se encaixar muito mais suavemente na argumentação de Laplanche, adotaremos “frustração” por uma questão de padronizar a tradução que vínhamos utilizando até aqui e que encontramos mais freqüentemente em outras obras.
} 
condição de frustração a que também o analista estaria submetido seria de dois tipos: a frustração em intervir no "real”, ou a frustração de realizar uma intervenção adaptativa (manipulação ou conselhos); a frustração do acesso ao saber, que seria ao mesmo tempo estar frustrado e um frustrar-se em relação ao saber:

Pois o saber não é algo que se tem e é motivo de desafio: "tem, não tem", mesmo que fantasticamente isso possa aparecer assim em certos momentos do tratamento. Mesmo os pais - pois comparo, neste ponto, a situação da análise e a situação em que a criança pede em vão um saber sexual que lhe é recusado -, afinal de contas, o que eles sabem? E o que poderiam comunicar do que sabem sexualmente [LAPLANCHE, 1993, p.241].

O que Laplanche faz é localizar num aspecto específico da vivência infantil (a relação de frustração, ou de recusa, com o saber) o fator preponderante da produção da transferência. Vemos que o que se coloca em questão não é um saber qualquer, mas um saber sobre o sexual, sobre as pulsões. Também não se trata de uma relação qualquer com esse saber, pois apesar de ambos os atores não poderem realmente saber, a um dos atores é atribuída fantasticamente essa capacidade: a criança atribui aos pais enquanto o analisando o faz com o analista.

Que significa, portanto, não ter o nível de saber necessário? Significa que os elementos psíquicos e somáticos não estão presentes para dar um sentido ao prazer sexual ou às propostas sexuais, ou às mensagens sexuais do adulto. O que pode ser dito também assim: a criança não conhece o prazer do orgasmo pleno, e deste modo não pode assimilar o que lhe comunicam. Essa perspectiva freudiana (que é também a de Ferenczi) sobre o "saber" deve ser retida no espírito. Só ela permite "ressituar" esta fórmula de Lacan, seguramente verdadeira, mas insuficiente: "tão logo haja em alguma parte o sujeito suposto saber, há transferência” [LAPLANCHE, 1993, p.238].

A diferença de possibilidade de acesso ao sexual promove a diferença de saber, e essa diferença, por sua vez, reproduzida na análise, promove a transferência. Neste sentido, além da condição de isolamento da realidade, a transferência depende então de um “suposto saber”, uma condição de assimetria sobre o saber sexual, em que ambos os personagens não detêm 
um saber real, mas cuja condição de frustração evoca uma reação pulsional que culmina nas produções fantasmáticas envolvidas na transferência.

Reorganizemos nossas informações, sinteticamente, para verificar a inserção institucional como continente das transferências de defesa egossintônicas e como produtor de relações transferenciais. A situação analítica se configuraria como uma reedição fantasmática de complexos parentais. O que tratamos por continência das defesas primitivas aderidas às pulsões recalcadas seria possível, na análise, pela possibilidade do analista ocupar, na fantasia, o lugar dos pais; o analista se associaria não apenas ao ego, como consideramos antes, mas ao superego e ao ideal de ego, o que permitiria uma distinção suficiente das pulsões egossintônicas para que também elas pudessem ser rearranjadas e realizadas na transferência. Reunimos, também, dessa configuração fantasmática, seus desdobramentos na realização e produção transferencial. Enquanto realização pulsional, pela aproximação às condições já exploradas pelo método sugestivo, se derivaria uma função educativa da análise, que, pela maturação da transferência, seria capaz de promover o desenvolvimento de um funcionamento infantil para um funcionamento mais autônomo. Enquanto produção transferencial, o isolamento produzido pela condição de frustração do saber sexual imposto na situação analítica, bem como a reprodução da assimetria infantil em relação a esse suposto saber sexual, seriam os fatores que incitariam a evocação do fenômeno transferencial. O que extraímos desse material é a complexa cena fantasmática em que se realizam e se rearranjam as forças pulsionais e as defesas primitivas de que tratamos no item anterior, para a formação dos desejos e da própria subjetividade. Essa cena se organiza em torno da relação do infans com seus pais sobre um saber sexual, nos termos de Laplanche, que, na verdade, por se tratar de um saber sobre as pulsões, é sempre um suposto saber. É a clara distinção desses lugares, do lugar onde o saber pode ser suposto (pais) e do lugar onde ele é vivido como desejo de saber (infans), o que configura e mobiliza a transferência; quanto mais clara essa 
diferenciação, maior a possibilidade de influência do analista no interior da transferência. É nesse ponto que localizamos a inserção institucional. Afirmamos que a instituição não poderia cumprir a mesma função do analista, pois não se trata de um indivíduo; no entanto, se é claro que a instituição não pode cumprir a mesma função de uma pessoa, pode ela muito bem ser cena, e nesta medida dispor dos papéis que poderão ser ocupados pelas pessoas. A condição de frustração da situação analítica é também condição das relações institucionais, em que o saber sempre extrapola as dimensões do indivíduo; a condição de isolamento das relações externas é também perfeitamente reconhecível no contexto institucional, ainda que possamos identificar outros elementos que não apenas o da frustração sexual para este isolamento; e se é a clareza dos lugares de investimento do suposto saber a condição de assimetria, o principal fator da produção da transferência e da possibilidade de associação ao ideal de ego e superego, temos nas condições hierárquicas das instituições uma intensificação exponencial dessa condição, que já na própria situação analítica clássica tem sua dimensão institucional. Chegamos à conclusão de que a inserção do institucional como continente e produtor da transferência é possível e verificável, porque já no setting clássico é a situação analítica, não o analista, a principal referência para a configuração da transferência. A instituição produz a transferência por oferecer todas as condições necessárias para que a cena fantasmática se instaure e é continente porque, apesar de não ser um outro como o analista, é capaz de investir a qualquer outro, por sua hierarquia, do poder do analista de influência e contenção das pulsões. Trata-se de uma inserção, dentro do contexto que estudamos, não de um terceiro, mas de um intensificador da possibilidade transferencial.

Resta ainda para esse capítulo adentrarmos o tema da realização fantasmática, agora não mais em sua estrutura, o que já realizamos, mas nos elementos que permitem sua realização. É tempo de verificarmos a pertinência de nossa segunda hipótese de inserção do institucional, como matriz de sentidos e objetos para a realização pulsional que configurariam 
a manifestação da relação analítica. Encerramos aqui o caminho que nos levou à inserção institucional como cena propiciatória e continente das pulsões transferenciais. Da dinâmica das pulsões, que nos apontou que uma continência só seria possível por uma associação ao aparelho psíquico, à organização fantasmática que nos mostrou o caminho dessa associação e os fatores de produção da transferência, percorremos um longo caminho, que nos afastou das hipóteses freudianas de que a manifestação transferencial fora da análise se daria exclusivamente por uma característica da neurose. Para realizar a transição do que trabalhamos para o nosso próximo tópico, em que consideraremos a natureza de algumas representações institucionais, trazemos uma citação de Laplanche (1993, p.242):

Passo a um inventário, necessariamente incompleto e prematuro, sobre os
lugares onde poderia verificar-se uma transferência analítica. Em Freud, o
primeiro exemplo que lhe ocorre é dos "estabelecimentos de cuidados". Ele o
repetiu em duas ou três oportunidades. [...] De forma muito parcial, Freud vê
nesse fato uma prova de que "essas particularidades da transferência não são
imputáveis à psicanálise, mas sim à própria neurose" [Artigos sobre a técnica],
ao invés de perguntar-se se não haveria elementos similares na situação.
Caberia, sobretudo perguntar-se se não há igualmente aqui recusas
fundamentais: recusa do saber, característica, desde que ele existe, do poder
médico, e também recusa do adaptativo, que está excluído pelo próprio fato da
"tutela".

Se já demonstramos que a transferência analítica pode ocorrer no interior das instituições, resta-nos explorar agora como ela acontece e, identificando as similaridades entre as situações, descobrir quais características da instituição e da situação analítica a transferência nos revela.

\subsection{A TRANSFERÊNCIA DE TRANSFERÊNCIA E OS PAPÉIS INSTITUÍDOS -}

$\underline{\text { O(S) PAPEL(IS) REPRESENTADO(S) PELO ANALISTA }}$

Para a exploração de como, na transferência, as pulsões se apropriam das cadeias de sentido oferecidas pela dimensão institucional para realizar-se, comecemos por apontar uma característica da transferência em relação a sua aderência às representações. Trata-se de uma 
observação de Laplanche (1993) sobre a transferência no caso Dora (FREUD, 1905/1972): a transferência de transferência, ${ }^{9}$ ou seja, a transferência que não é mera passagem de uma cena à outra. Enquanto a transferência de Dora para com o sr. K. remete à relação com seu pai (algo que estaria dentro do esperado), a transferência para Freud não traz elementos apenas da relação com o pai, mas remete também à transferência que ela estabeleceu com o sr. K. Elementos vividos na transferência com o sr. K. são transferidos para a relação com Freud. Além dessa transferência de transferência, que poderíamos considerar cronológica (pai - sr. K. - Freud), Laplanche aponta também que a própria transferência de Dora para o sr. K. era também atravessada por outra personagem, mas que não estava distante no tempo: a sra. K. O interesse de Dora pelo sr. K. estava intimamente ligado ao fato dele estar vinculado à sra. K., ou seja, a uma transferência à sra. K. Laplanche (1993, p.204) sintetiza o interesse que esse caso apresenta:

\begin{abstract}
A transferência não está fechada sobre si mesma, não é uma relação a dois, reeditando sempre uma outra relação a dois; a transferência está aberta para outra coisa que não ela mesma, tanto na linha cronológica em que já temos pelo menos três personagens (Freud, sr. K., o pai) quanto igualmente a constelação intersubjetiva presente, sincrônica, em que ela se compreende pelo acesso, através do sr. K., à sra. K.
\end{abstract}

Sublinhemos o seguinte: a transferência, em relação à associação que promove entre os personagens, não opera uma transposição direta entre um evento no passado e outro na atualidade (ou pelo menos pode não operar), e está aberta a uma “constelação intersubjetiva”. Essa constelação intersubjetiva em ação na transferência pode se localizar tanto na história do sujeito quanto estar atualmente presente. O interesse dessa constatação para os nossos problemas é evidente: a instituição como extensão do setting oferece uma gama muito mais ampla de suportes transferenciais, uma constelação intersubjetiva muito mais rica que a

\footnotetext{
${ }^{9}$ Uma discussão mais pormenorizada sobre a transferência de transferência no caso Dora pode ser encontrada em Laplanche (1993).
} 
condição analítica clássica. Como conseqüência, o analista tem a possibilidade de observar muito mais elementos que podem ser a ele transferidos por uma associação a outros personagens presentes na instituição, mas tem também, em contrapartida, uma dificuldade muito maior em identificar e isolar esses elementos. Observada essa possibilidade de multiplicidade da transferência, passemos para sua relação com papéis instituídos.

Ferenczi, em 1909, nos apresenta uma idéia interessante sobre o envolvimento de papéis instituídos (no caso, a figura do médico) na transferência:

\begin{abstract}
Com freqüência, os pacientes aproveitam-se das circunstâncias [da análise] para reencontrar sensações sexuais experimentadas durante exames médicos anteriores e depois recalcadas: fantasias inconscientes de tirar a roupa, de auscultação, palpação, operações essas em que o médico de outrora é substituído, sempre inconscientemente, pela pessoa do terapeuta atual. Para suscitar essa transferência, basta que o próprio analista seja também médico. O papel místico que desempenha nas fantasias sexuais infantis o médico que conhece todas as coisas proibidas vê e toca no que está escondido, é em si um determinante natural das fantasias histéricas e da transferência [FERENCZI, 1909/1991, p.80, grifo nosso].
\end{abstract}

Essa idéia, pouco desenvolvida no artigo, menciona ainda que a associação entre a figura do médico e a sexualidade aconteceria desde a infância, através das brincadeiras de médico, que serviriam à satisfação da curiosidade sexual infantil. Apesar de breve, essa passagem nos oferece uma possibilidade de interação entre transferência, instituição e clínica, pela figura instituída do médico. A transferência de fantasias inconscientes para o analista aparece associada à transferência de experiências vividas com o médico (mesmo que estas também tivessem relação com fantasias que a princípio não tinham a figura do médico como referência - mecanismo de transferência de transferência). Além disso, notamos que a disposição do paciente em transferir para o médico suas fantasias sexuais inconscientes não o toma como figura indiscriminada: se importa pouco quem é o médico, importa que seja médico. É ao perceber o analista como médico que o analisando poderia com maior facilidade transferir seus complexos sexuais infantis para aquela relação. Há uma verdade sustentada 
pelo discurso institucional (no caso o médico como detentor do saber sobre o corpo, e do direito de tocá-lo) que é anterior ao depósito fantasmático do sujeito e que o favorece. Porém, esse argumento sozinho não é suficiente para sustentar uma análise das representações institucionais na transferência, uma vez que se poderia alegar que a única representação institucional que encontramos na psicanálise refere-se a sua herança médica. Necessitamos então da emergência de outra representação, para que possamos ter referência do quanto essas figuras interferem no campo transferencial. E não é preciso ir longe da experiência de qualquer analista que algum dia foi ou é iniciante para encontrarmos essa representação: o professor/mestre. Discutimos o quanto uma assimetria na relação de saber tem profunda ligação com a própria possibilidade de transferência, e referimo-nos agora a uma representação institucional (professor-aluno) ainda mais explícita, que pode se verificar nas análises didáticas, intimamente ligadas com a instituição da psicanálise.

Tendo em vista as análises didáticas, o referencial médico/terapêutico predominante nas situações de origem da psicanálise sofre uma sensível modificação: a demanda de cura torna-se demanda de conhecimento, o paciente torna-se aluno, e o médico, mestre. Haynal (1995), discutindo os procedimentos técnicos de Freud, ${ }^{10}$ questiona o quanto alguns deles estariam relacionados ao fato de Freud estar trabalhando com alunos:

Freud descreveu uma cena durante a qual ele tem o sentimento de que seu paciente exprime inconscientemente, em relação a ele, um pensamento hostil, deixando aberta a porta do consultório (sabendo que nenhuma outra pessoa chegará para uma sessão de análise); recomenda dar uma "bronca" nos pacientes para evitar que se comportem de modo não-educado e desrespeitoso [Freud, Introductory lectures on psychoanalysis I, 1917-1917, 16:247]. Estaria isso ligado ao estilo da época ou ao fato de que ele não tinha praticamente mais do que estudantes em análise? [...] Será então que certos conselhos de Freud devem estar ligados ao fato de que se destinam a analisandos que são seus "alunos”? [HAYNAL, 1995, p.7-8.]

\footnotetext{
${ }^{10}$ Cf. o capítulo "Prolegômeno: Freud". O autor discute a transmissão técnica de Freud, com atenção especial à questão da transferência, com base em seus escritos técnicos/propositivos e nos relatos de pacientes por ele atendidos.
} 
A questão da relação mestre/aluno acompanha a psicanálise talvez há tanto tempo quanto a relação médico/paciente, não só pela questão das análises didáticas, mas também pela pretensão de Freud de fazer da psicanálise, mais do que uma simples alternativa terapêutica, um campo do saber. Poderíamos dizer até que é anterior à relação médico/paciente se tomarmos como referência a relação Freud/Fliess, que está na fundação da psicanálise. ${ }^{11}$ Entretanto, ambas as relações, que se apóiam na cadeia de sentidos oferecida pela dimensão institucional, mantêm-se encobertas e latentes na discussão sobre o campo transferencial, pois apontam para uma direção que se choca com os princípios da análise.

Há entre o analista, seu analisando e a Instituição a que estão ligados um acordo sem questionamento possível: o objetivo da análise de formação é formar um analista. [...] Com o mesmo direito que para a análise "didática", pode-se perguntar em que medida uma análise que aceita sem crítica a intenção "terapêutica" continua sendo uma análise. [...] Nos dois casos, tanto o "didático" quanto o "terapêutico", o problema é saber [...] se essas metas devem ser admitidas no início de um processo analítico, ou se não são, elas próprias, parte integrante do que deve ser recolocado em questão pela análise [LAPLANCHE, 1993, p.114].

A inserção da dimensão institucional como suporte representacional da relação analítica é muito mais visível do que nossa discussão anterior. No entanto, o problema que se

\footnotetext{
11 Sobre a relação entre transferência e saber e a transferência original de Freud a Fliess, Laplanche (1993, p.236): “a transferência de Freud situa-se [...] numa demanda que é uma demanda de saber [demanda de Freud pela aprovação de Fliess sobre suas idéias]. [...] essa demanda de saber incide sobre o sexual. [...] As mensagens de Fliess (neurose nasal, bissexualidade, periodicidade), tanto quanto é possível reconstituí-las, versam sobre o sexual, e é enquanto tais que dão ensejo à perlaboração. Meu ponto seguinte é que não apenas a demanda incide sobre o saber sexual, mas que a transferência tem a ver com um segredo sobre o saber”. Esse segredo aponta para uma dissimetria na relação com o saber, em que um é suposto saber (Fliess) e outro demanda saber (Freud). "Por isso desencadeia-se algo que é uma reprodução direta da situação dissimétrica na qual se engendra, para a criança, a sexualidade. Essa dissimetria, esse desafio do saber, exprime-se pelo termo segredo” (LAPLANCHE,
} 1993, p.237). 
apresenta neste caso não é a verificação da existência do institucional, mas a existência da própria análise quando o institucional vem à tona. As metas, ou representações-meta, que Laplanche questiona se não deveriam ser elas mesmas colocadas em questão pela análise, só puderam e podem existir sem esse questionamento, pois se apóiam em relações que estão presentes na própria relação transferencial que sustenta uma função analítica. Sobre a dificuldade de abandonar as representações-meta (extinção do sintoma, formação profissional) e se entregar à regra da associação livre:

A meta de curar, ou a meta às vezes profissional, estão inteiramente enredadas com a transferência e com essa outra representação que faz do analista o mestre da saúde, o mestre do sintoma, ou também o mestre possível da carreira profissional, se carreira houver. É evidente que a idéia mesma de depender do analista, no discurso que iremos pronunciar, no momento mesmo em que lhe pedimos para nos libertar ou nos conduzir a alguma parte, é um dos obstáculos maiores à observância da regra fundamental. Afinal, quem iria insultar seu dentista no momento em que este vai nos introduzir a broca na boca? [LAPLANCHE, 1993, p.158.]

Deparamo-nos com dificuldades definitivamente invertidas, em que procuramos localizar a análise no institucional e não o contrário, o que só tende a se ampliar no contexto em que analisamos a prática psicanalítica: o atendimento num hospital, ou numa escola, por exemplo, intensificaria ainda mais a marca dessas representações-meta. Observamos, nesse quadro, a inserção institucional pelas representações-meta, a transferência pelas fantasias associadas aos papéis instituídos, mas custa-nos encontrar onde essa relação poderia ser considerada verdadeiramente analítica. A saída para esse impasse encontra-se no analista: a análise, nesse contexto, sobrevive pelo reconhecimento do conflito no e pelo próprio analista e por sua disposição em ser fiel à regra fundamental.

Essa remoção das representações-meta conscientes só pode ser um processo, uma tarefa infinita assintótica, e não algo que é pronunciado de uma vez por todas; a regra fundamental é a regra de um certo devir. Por outro lado, a distinção entre representações-meta conscientes e representações-meta inconscientes talvez não seja perfeitamente pertinente, se recordarmos que as próprias representações-meta conscientes estão ancoradas no inconsciente. Será que não seria preferível formular as coisas desse modo: desaprendizagem, ou um 
progressivo deixar de lado as representações-meta adaptativas? Desaprendizagem para a qual a atitude do analista é um fator de primeira importância, e neste sentido Freud tem razão ao dizer que também o analista não pode escapar a essa regra fundamental [referência à resposta negativa de Freud ao homem dos ratos sobre o pedido de não contar sobre o suplício dos ratos], essa regra é imposta a ele próprio [LAPLANCHE, 1993, p.158-9].

A regra fundamental exige então não só do paciente, mas também do analista, uma renúncia à lógica e ao decoro, ligando-se ao campo das frustrações exigidas pelo tratamento. É somente pelo reconhecimento das limitações que a dimensão institucional impõe ao próprio analista que este pode instituir a análise como um meio de escapar às relações instituídas, relações que se sustentam na mesma esfera inconsciente de onde a análise tirará suas forças. Somos convocados, portanto, a investigar agora a contrapartida do analista na cena transferencial.

\subsection{CONSIDERAÇÕES INICIAIS SOBRE A CONTRATRANSFERÊNCIA}

Até o momento, entendemos a situação analítica em seu estatuto transferencial. Pela investigação sobre as condições da transferência na instituição, deparamo-nos frente à tarefa de compreender como o psicanalista pode trabalhar essas especificidades, sem que seja absorvido pela transferência e pelas representações institucionais. Para essa tarefa, abordaremos quais são as condições e quais são recursos que o psicanalista possui frente às dificuldades da transferência na instituição.

Em 1918, numa conferência dedicada à técnica psicanalítica ${ }^{12}$, uma das questões abordadas por Ferenczi é a da contratransferência. Partindo da descoberta dos mecanismos da transferência, Ferenczi nos chama a atenção ao quanto cada paciente pode ser mais, ou menos, suscetível a uma postura de mãe benevolente ou de pai severo. O psicanalista deve estar apto

${ }^{12}$ Cf. Ferenczi (1918/1992). 
a ocupar qualquer um dos dois lugares, ou até mesmo ora um, ora outro, adaptando-se ao caráter dos pacientes e à condição transferencial. Para adaptar-se a essas possibilidades diametralmente opostas de vinculação e ocupar a posição que a transferência do analisando lhe confere, o psicanalista se vê na incômoda situação de ter sob controle seus afetos e paixões. O maior problema dessa condição é que o controle dos afetos não é tarefa simples, pois o analista, tal como o analisando, também possui seus impulsos, variações de humor, simpatias e antipatias. Toda análise exigiria, então, um duplo esforço: a observação do paciente e de sua transferência, e a observação de si mesmo e da contratransferência. Trata-se de um esforço que não passa apenas pelos processos conscientes, e sua negligência tem conseqüências na comunicação entre terapeuta e paciente, como observa Ferenczi (1918/1992, p.366):

O médico entusiasta que, no seu desejo de curar e de explicar, quer "provocar" seus pacientes, negligencia os sinais, pequenos e grandes, da atração inconsciente que experimenta por seus pacientes de ambos os sexos, mas estes apercebem-se deles e deduzem corretamente dos mesmos a tendência que se encontra em sua origem, sem suspeita de que o próprio médico não tinha consciência disso. [...] O médico pode jurar que - conscientemente - só pensava em curar seu paciente; mas o paciente também tem razão, pois o médico arvorou-se inconscientemente em protetor ou defensor do seu cliente e deixou-o entrevê-lo através de diversos indícios.

Um dos pontos que nos interessam nessa apreciação da contratransferência é o da comunicação inconsciente entre terapeuta e paciente. Se a contratransferência pertence também - e por vezes até mais - ao campo do inconsciente, contornar tal situação não se trata de um ajuste meramente formal, algo que se resolva apenas com uma postura mais reservada. Aliás, se isto fosse o suficiente, seria um problema facilmente contornável pela postura psicanalítica. Ferenczi observa que a postura analítica oferece, no caso de um controle insuficiente da contratransferência, um paradoxo às percepções inconscientes do paciente. Sinais inconscientes contraditórios fazem com que a postura analítica, contrariando seu intuito de favorecer a transferência, configure-se como uma situação insolúvel que muitas vezes leva 
o paciente a abandonar o tratamento. A partir disto, Ferenczi reitera a importância da análise do analista como forma deste impedir que seus próprios sintomas manifestem-se no tratamento.

Por outro lado, não é só o controle insuficiente da contratransferência que pode trazer dificuldades ao tratamento analítico: o excesso de controle e rigidez, ou a resistência à contratransferência, pode também surgir como um obstáculo, retardando ou impossibilitando o estabelecimento da própria transferência. Uma vez que o analista procure resguardar todos os seus afetos em relação ao paciente, corre o risco de se tornar inacessível à transferência, e conseqüentemente ao trabalho de análise.

Como resolução desses problemas, Ferenczi trabalha com um ponto ideal do controle da contratransferência. Nesse ponto de controle ideal, o pré-consciente é apresentado como instância reguladora, emitindo sinais de alerta à consciência para os momentos em que se deve substituir o estado permissivo de entrega às associações, fantasias e afetos por uma atitude crítica. É a garantia dessa sentinela pré-consciente, conquistada pela análise do terapeuta e por sua experiência clínica, que lhe permitiria relaxar e poder oscilar entre uma atitude mais empática e favorável à transferência, por um lado, e uma atitude mais analítica, por outro.

Sublinhemos alguns pontos que interessam aos nossos objetivos. Se o paciente pode perceber, inconscientemente, sinais de afeto do analista mesmo que este não tenha consciência de emiti-los - primeiro problema que faz necessário o controle da contratransferência -, podemos deduzir daí que há uma possibilidade de acesso ao psiquismo do analista por parte do paciente na situação analítica, mesmo que esse movimento nem sempre seja considerado pelo trabalho de análise. Tal acesso do paciente aos afetos do terapeuta é, até este ponto, entendido como problema, pois reduziria as possibilidades do tratamento, no máximo, a uma cura pela sugestão, uma vez que as relações estabelecidas entre 
terapeuta e paciente apenas reproduziriam as relações eróticas infantis do par, sem consciência de ambos sobre esse funcionamento. Ao avaliarmos o contexto institucional, além da exposição a que o analista está sujeito pela transferência, observamos também uma outra exposição do analista: seu papel institucional. Quando o paciente trata seu psicólogo, em um hospital, como seu curador, ou seu analista didata como um tutor, ele não está equivocado. Entretanto, tal percepção também pode ser considerada, tal como a percepção dos afetos reprimidos do analista, como prejudicial ao processo de análise. O não reconhecimento desta representação institucional também pode acarretar um paradoxo para o paciente, e a resistência do analista em ocupar os papéis institucionais a um não estabelecimento da transferência. O que obtemos então é um quadro que intensifica significativamente a contratransferência a que está sujeito o analista, uma vez que somada à condição de transferência temos o acréscimo da condição institucional. Se seguirmos o caminho de Ferenczi, vemos, por parte do analista, a reação a essa intensificação se refletir num aumento da resistência à contratransferência para que se garanta o trabalho. Em reação a essa superexposição, podemos encontrar nas instituições o distanciamento e a formalidade, a subtração dos sujeitos e a dificuldade ou impossibilidade da configuração da transferência analítica, pois o analista deixa de cumprir seu papel guardião. Em instituições, vemos a facilidade com que pessoas reduzem-se a casos, fichas ou relatórios, ou como as regras institucionais de tempo e espaço acabam internalizadas como defesa à exposição aos pacientes. Inclusive, essa etapa de reação à contratransferência não é exclusiva de profissionais de psicologia, mas comum a outros atores da instituição.

Analisemos também essa primeira resolução proposta por Ferenczi. Trata-se de dominar a contratransferência para que se possa estabelecer a análise. A princípio, podemos considerar que o contexto institucional não altera a característica dessa recomendação técnica - exceto pela maior dificuldade em alcançá-la -, uma vez que o controle da 
contratransferência, considerado como algo internalizado e depositado no pré-consciente, seria suficiente para recolocar a análise em seu rumo, esteja onde ela estiver. Mas será que essa exposição institucional tem os mesmos efeitos no analista que transferência, desdobrando-se nos mesmos processos de contratransferência? Seria o controle a única possibilidade para a contratransferência e para as conseqüências da exposição institucional do analista? Para tratar dessas questões abordemos algumas outras contribuições acerca do papel do analista.

\subsection{A TÉCNICA ATIVA}

Na mesma conferência em que comunicou suas considerações sobre a contratransferência, Ferenczi também apontou alguns problemas que constatara em relação à “técnica clássica” da psicanálise. Em sua comunicação o autor apontou, através de experiências clínicas, o quanto a técnica de associação livre e a atenção flutuante poderiam, com o decorrer da análise, servir à resistência ao tratamento. Essa constatação trazia a implicação lógica de colocar em xeque a postura passiva do analista, uma vez que sem a associação livre e a atenção flutuante o psicanalista teria de recorrer a outro material para poder interpretar, material que só poderia ser conseguido se abandonasse sua postura passiva. A exploração das possibilidades do analista para superar esse impasse levou Ferenczi a desenvolver o que denominou de técnica ativa.

Essa técnica tinha por base a idéia de que o esgotamento e a esterilidade das associações eram freqüentemente explicados por uma retirada da libido do trabalho analítico, em benefício de fantasias inconscientes. Naturalmente, esse deslocamento era o resultado e o indício de uma crise na relação transferencial, e o analista tinha então como tarefa descobrir para que terreno a libido se deslocara e mobilizá-la a fim de que ela se tornasse novamente disponível para um trabalho fecundo. [...] A intervenção ativa do analista pode assumir, então, duas formas. $\mathrm{O}$ analista pode convidar o paciente a não se entregar mais ao hábito em questão, em outras palavras, a renunciar à satisfação indireta de seus desejos recalcados; ou, ao contrário, pode encorajar o paciente a desfrutá-la aberta e livremente. $\mathrm{O}$ analista espera, assim, [...] provocar no paciente um 
considerável aumento de tensão, que [...] poderia acarretar duas conseqüências: a irrupção na consciência de uma moção pulsional ou de uma pulsão até então recalcada, transformando um sintoma fonte de desprazer numa satisfação acompanhada de prazer, o que leva a um reforço e a uma extensão da autoridade do ego do paciente, e à reativação das associações esgotadas ou estagnadas do paciente pela supressão das resistências [BALINT ${ }^{13}, 1967$, apud DUPONT, 1968/1993, p.VIII-IX].

Ferenczi lança mão da técnica ativa para enfrentar os momentos de estagnação na análise, em que a "técnica clássica” não parecia fazer efeito. Baseado no princípio de frustração $^{14}$ de Freud, Ferenczi contava que, com o aumento da tensão provocada por interdições ou injunções por parte do analista, o paciente seria levado a canalizar essa energia para sua cura. Seus anos de experiência com a técnica ativa tiveram como fruto grandes sucessos terapêuticos - é certo também que houve grandes fracassos - e marcaram o desenvolvimento de sua teoria da genitalidade ${ }^{15}$. Não é de nosso interesse explorar todos os desdobramentos teóricos da técnica ativa; focaremos algumas de suas nuanças que levantam questões importantes para a técnica psicanalítica como um todo e podem de alguma forma nos auxiliar.

A técnica ativa põe em evidência a questão da “sugestão” psicanalítica. O próprio Freud (1917, p. 527), com o reconhecimento da importância da transferência para o processo analítico, reconhece também que o processo de sugestão pode ter uma nova compreensão à luz das descobertas psicanalíticas.

Na psicanálise, agimos sobre a própria transferência, deslindamos o que nela se opõe ao tratamento, ajustamos o instrumento com o qual desejamos causar nosso impacto. Assim, se nos torna possível auferir uma vantagem inteiramente nova do poder da sugestão; ela passa para nossas mãos.

\footnotetext{
${ }^{13}$ Balint, M. Techniques psychanalytiques, Basic Books, 1967.

${ }^{14}$ Estado psíquico que consiste em “deixar insatisfeitos os desejos e as exigências emitidos pelo paciente na transferência, mormente o seu imenso desejo de afeição e a sua tendência para instalar-se na análise, de certo modo, por toda a vida” (FERENCZI, 1925/1993, p.328).

${ }^{15}$ Cf. Thalassa (1924/1993), in: Obras completas, vol. III.
} 
Ferenczi se preocupa bastante em diferenciar a "sugestão” psicanalítica de outros métodos terapêuticos de hipnose e sugestão. Citemos esta distinção:

\begin{abstract}
Os métodos precedentes de sugestão consistiam, de fato, em querer persuadir o paciente de uma mentira consciente ("Você não tem nada" - o que é certamente inexato, visto que o paciente sofre de neurose). As "sugestões" psicanalíticas utilizam a transferência para permitir ao paciente convencer-se pessoalmente dos motivos inconscientes de seu sofrimento; além disso, o próprio psicanalista deve cuidar de que a crença assim adquirida não seja uma "fé cega", mas a convicção pessoal do paciente escorada em suas lembranças e em sua vivência atual ("repetição") [FERENCZI, 1920/1993, p.111, grifo nosso].
\end{abstract}

A “sugestão” psicanalítica surge então como a influência do analista na educação do ego do paciente, sendo que esta se diferencia da sugestão clássica por não ser um fim em si mesma, exigindo uma verificação de outra ordem. Já analisamos em outro momento o porquê dessa possibilidade transferencial de sugestão pela associação aos complexos parentais. Retomemos esse ponto, chamando atenção agora para a questão da utilização da transferência naquilo em que ela se confunde com a sugestão clássica. Em outra passagem:

A educação do ego [...] é uma intervenção francamente ativa ao alcance do médico em virtude de sua autoridade aumentada pela transferência. [...] A influência exercida sobre o paciente é certamente algo de ativo, e o paciente reage passivamente a esse esforço do médico (FERENCZI, 1920/1993, p.111, grifo nosso).

Há uma íntima relação entre transferência, educação, autoridade e atividade. A transferência investe o analista de uma autoridade e esta é utilizada como influência sobre o paciente em análise. Retomamos este ponto, pois é a partir dele que podemos entender a técnica ativa como uma experiência significativa, dentre os recursos que a psicanálise já dispôs frente à transferência. A técnica ativa leva ao limite o uso da influência transferencial, com o analista solicitando ao paciente que atue contra o princípio de prazer e se coloque em situações desagradáveis, em prol da análise e à custa desse “poder” transferencial. A relação entre esse “poder” e o contexto das coletividades é dado pelo próprio Ferenczi: 
$\mathrm{O}$ analista age sobre os pacientes à maneira do déspota que não ama ninguém ou que todo o mundo ama; tal como este, assegura-se do apego do analisando ao interdizer-lhe certos modos de satisfação correntes, e a influência assim adquirida vai lhe servir para elucidar o material recalcado e, finalmente, para dissolver esse mesmo apego [FERENCZI, 1925/1993, p.338].

Temos em evidência na atividade, mas presente também na essência da técnica psicanalítica clássica, uma relação de influência que remete à psique das massas, mais especificamente a organização da horda. Essa parte mais primitiva da psique é, pela técnica ativa, restaurada no homem em um contexto de sua saúde, como etapa decisiva do sucesso de uma análise. Entretanto, a atividade, ao mesmo tempo em que restaura essa condição ao homem, no lugar do paciente, apresenta seu contraponto na figura do analista: a desproporção de poderes faz despertar pulsões sádicas e autoritárias, também primitivas, que exercidas só vêm a prejudicar o paciente. Como discutido em relação à contratransferência, a resistência do paciente ao tratamento encontra nessa contrapartida por parte do psicanalista condição favorável para se desenvolver.

Ao trabalhar nesse limite do uso da transferência positiva como modo de influência, Ferenczi estava ciente dos riscos que corria, do quanto essas atitudes poderiam servir à resistência do paciente e poderiam fazê-lo desligar-se do tratamento - não por acaso, ele recomendava o uso da técnica ativa somente quando se possui indício seguro da solidez da transferência e apenas em casos excepcionais, em que outros recursos já falharam. Do início, quando oferecia interdições e injunções claras direcionadas a comportamentos de seus pacientes (primeiro dentro e depois também fora das sessões), e por vezes até delimitava o prazo para o término da análise, até o momento em que abandonou a atividade, Ferenczi se deparou com a repetição de alguns fracassos, fruto de excessos cometidos que geraram a exacerbação da resistência do paciente. Sobre a resistência à influência mais ativa do analista:

A atividade, na medida em que se propõe a aumentar a tensão psíquica mediante recusas, injunções e interdições desagradáveis - a fim de obter um material novo, vai exacerbar inevitavelmente a resistência do paciente, ou seja, incitar o ego do paciente a opor-se ao analista. [...] A atividade, enquanto 
medida de frustração, tem, sobretudo por efeito [...] perturbar e desfazer a transferência [FERENCZI, 1926/1993, p.366].

A relação intrínseca entre atividade e resistência foi o que levou Ferenczi a abrir mão, aos poucos, da técnica ativa. Suas sugestões passaram a depender cada vez mais de um acordo com o paciente e foram se tornando mais restritas frente às resistências intensas enfrentadas em análise - seja por parte do paciente, seja na percepção da contratransferência. A forte resistência disparada pela técnica ativa remete também a um funcionamento das tribos primitivas: o poder de influência do chefe (seu mana) está condicionado ao bom uso de seu poder. ${ }^{16}$ Quando o analista passa a fazer uso de seu poder de influência para gerar situações de desprazer (e por vezes até em função de um prazer próprio) ele sai do papel que lhe dá o poder de influência. Nessa análise, trata-se de um ataque à transferência, não pela resistência à sua manifestação, mas pelo ataque à posição em que ocupava na fantasia primitiva do paciente.

A partir dessas considerações acerca da técnica ativa, voltemos às questões sobre a transferência de transferência que têm em suas séries representações institucionais e retomemos, a título de exemplo, o caso da representação professor-aluno. Na infância, o professor vem substituir os pais em nossa educação, e a relação com ele nos primeiros momentos é muito similar à que temos com nossos pais, com a diferença de se concentrar numa mesma pessoa e ser partilhada por muito mais irmãos - o resto da classe. Se as experiências médicas remetem ao corpo e à curiosidade sexual, as experiências escolares remetem a relações de dependência por parte do aluno e de onipotência por parte do professor. Ao analisando/aluno restam as fantasias primitivas ambivalentes em relação a essa entidade poderosa que pode tanto dar quanto tirar-lhe tudo. Para o analista/professor, a

\footnotetext{
${ }^{16}$ Ver "O tabu relativo aos governantes”, na parte II, “Tabu e ambivalência emocional”, de Totem e tabu. No próximo capítulo abordaremos mais sistematicamente as relações inconscientes envolvidas nas coletividades.
} 
questão parece mais difícil: a contratransferência neste caso traz à tona fantasias onipotentes que podem se concretizar às custas do sofrimento dos pacientes. Haynal (1995) nota que Freud é muito mais ativo em suas intervenções e despreocupado com a neutralidade psicanalítica, quando está envolvido na análise de seus alunos ou em determinados momentos de desenvolvimento de sua teoria ${ }^{17}$, ou seja, quando ele está envolvido em seu papel de professor. As fantasias sádicas e onipotentes a que o analista está sujeito estão intimamente relacionadas a uma posição de poder, por sua vez ligadas a uma postura mais ativa, do analista. As descobertas experimentadas pela técnica ativa, além de nos oferecerem uma alternativa para lidarmos com a transferência na instituição - como uma possibilidade de influência ao paciente - nos oferece uma resposta à nossa questão sobre os efeitos do contexto institucional sobre o analista. A instituição - em especial a que se refere ao par professor aluno -, ao ampliar os poderes de influência do analista, amplia suas fantasias sádicas e onipotentes perante seu paciente.

Tomemos por ilustração uma situação concreta para facilitar nosso caminho, e sintetizar alguns conceitos que procuramos trabalhar. Em minha formação, tive a experiência de realizar diversos atendimentos na clínica-escola do Instituto de Psicologia da Universidade de São Paulo. Do público que procurava atendimento, num primeiro momento, encontrávamos a expectativa do poder de cura depositado na figura dos cuidadores. Em contrapartida, os alunos, em seus primeiros atendimentos, viviam a expectativa de transpor seus conhecimentos teóricos para a prática, ansiosos por verificar que seus conhecimentos pudessem promover mudanças. Não desconsideremos ainda que o lugar desse encontro é a universidade, lugar vinculado à produção de saber mais que à promoção de cura. Desenhado esse cenário, o que podemos verificar é o favorecimento do "poder de influência”, ou o aumento do poder de sugestão do jovem terapeuta; não me refiro aqui à qualidade ou

\footnotetext{
${ }^{17}$ Cf. "Prolegômeno: Freud”, in: A técnica em questão... (1995).
} 
funcionalidade das intervenções, mas à sua aceitabilidade por parte dos pacientes. Podemos verificar tal aumento de influência na diferença que jovens terapeutas encontram em seus atendimentos vinculados à universidade, onde gozam na maioria das vezes de grande prestígio logo nas primeiras sessões, para seus atendimentos particulares no início de carreira, quando a juventude pesa como um fator de desconfiança. Temos então uma dinâmica de influência que tem como ponto de partida uma relação institucional e precede a transferência para a figura do analista. Cabe ressaltar que essa relação, que precede a figura do analista, carrega as representações do sujeito ligadas ao universitário, que por sua vez está associado às representações da universidade. Essa relação com o universitário tem como sombra a figura do professor, detentor dos saberes e poderes que pode nos orientar frente aos problemas do mundo, potencializada pela marca da Universidade de São Paulo; as fantasias primitivas de onipotência que puderam ser depositadas nas figuras dos mestres e professores, desde a infância, podem, então, somarem-se ou substituírem a transferência e fazer com que os pacientes recebam as falas de seus terapeutas com bastante benevolência. Todavia, tal como na técnica ativa, proporcional ao uso dessa maior influência, há o aumento dos riscos de resistência. Na instituição, o paciente/aluno tem dificuldade para se tornar analisando; busca uma terapêutica para seus problemas, se possível em soluções breves ou, no caso de sentir benefícios em sua relação com a instituição, prolonga seu tratamento por anos na clínicaescola, trocando de terapeuta (dado o caráter transitório do vínculo dos terapeutas com a instituição) e recomeçando suas queixas ano após ano. ${ }^{18}$

Com esses elementos, talvez possamos encontrar outros esclarecimentos sobre a observação de Freud em relação à manifestação comum da transferência negativa nas

18 No terceiro capítulo abordaremos alguns casos clínicos nos quais exploraremos em mais detalhes a configuração transferencial, inclusive em relação à influência da Universidade para o contexto transferencial. Por ora nos interessa apenas demonstrar alguns desdobramentos mais genéricos para facilitar a compreensão de nossos conceitos. 
instituições. A possibilidade de influência movida não pela transferência, mas pela relação enquadrada pela instituição, pode servir de configuração para medidas ainda mais autoritárias e sádicas por parte do analista, que tem seu "poder” potencializado pela dinâmica intersubjetiva da instituição. Porém, como pode se observar com a técnica ativa, não se trata de impossibilidade de trabalho analítico - uma vez que a influência ou a "sugestão" psicanalítica coexistem com os princípios da análise -, mas da observação mais atenta das resistências evocadas, bem como - e talvez principalmente - da contratransferência e dos efeitos da instituição sobre o analista. Pela intensificação do poder de influência do analista em um contexto institucional, mesmo o componente ativo presente em uma interpretação, que muda o rumo das associações de um paciente, pode resultar numa intervenção muito mais restritiva.

A partir da técnica ativa pudemos identificar uma das possibilidades do analista lidar com o contexto institucional enredado na transferência (a utilização da intensificação da sugestão psicanalítica). Entretanto esta possibilidade é limitada pela intensa resistência evocada por sua contrapartida no analista. Consideremos agora outras possibilidades de resposta à nossa questão dos recursos de que dispõe o analista frente a transferência institucional.

\subsection{A ELASTICIDADE DA TÉCNICA PSICANALÍTICA:}

TATO PSICOLÓGICO E PRÍNCÍPIO DE RELAXAMENTO

Em 1928, Ferenczi fez uma comunicação sobre a elasticidade da técnica psicanalítica. $^{19}$ Esse texto apresenta um amadurecimento de Ferenczi em relação a suas

\footnotetext{
${ }^{19}$ Elasticidade da técnica psicanalítica, in: Obras completas, vol. IV. Conferência proferida na Sociedade húngara de psicanálise - ciclo de 1927/1928.
} 
experiências com a técnica ativa, bem como as bases da nova fase de suas experiências técnicas.

Aceito fazer minha a expressão "elasticidade da técnica analítica” forjada por um paciente. É necessário, como uma tira elástica, ceder às tendências do paciente mas sem abandonar a tração na direção de suas próprias opiniões, enquanto a falta de consistência de uma ou outra dessas posições não estiver plenamente provada [FERENCZI, 1928/1992, p.31-2].

A proposição de uma elasticidade da técnica psicanalítica, ao mesmo tempo em que amplia as possibilidades do analista no campo técnico, nasce da percepção das limitações encontradas com a técnica clássica e também com a técnica ativa utilizada por Ferenczi. Ao observarmos com atenção, notamos que a elasticidade acrescenta, ou pelo menos recoloca com mais evidência, a questão do analista ter de ceder às tendências do paciente com o mesmo equilíbrio que deve defender suas próprias posições. Nesse mesmo texto, Ferenczi expressa claramente o quanto o analista não deve ficar inibido em reconhecer seus erros frente ao analisando e reforça o quanto o elemento a ser preservado na análise é a franqueza do analista e não o seu prestígio. Se a técnica ativa reforçava o lugar de poder do analista e de submissão do analisando, despertando assim grandes resistências, com a elasticidade Ferenczi recoloca o lugar do analisando como ponto de tensão para as intervenções do analista, diminuindo a diferença de poder entre esses dois pólos. Para esclarecer a maneira pela qual o analista poderia manusear esta elasticidade, que por definição não tem contornos fixos, o autor sugere o conceito de tato psicológico.

O tato é a faculdade de "sentir com" (Einfühlung). Se, com a ajuda do nosso saber, inferido da dissecação do nosso próprio eu, conseguirmos tornar presentes as associações possíveis ou prováveis do paciente, que ele ainda não percebe, poderemos - não tendo, como ele, de lutar com resistências - adivinhar não só seus pensamentos retidos, mas também as tendências que lhe são inconscientes. Permanecendo ao mesmo tempo e a todo momento atentos à força da resistência, não nos será difícil decidir sobre a oportunidade de uma comunicação e a forma de que deve revestir-se. Esse sentimento nos impedirá de estimular a resistência do paciente, de maneira inútil ou intempestiva [FERENCZI, 1928/1992, p.27]. 
Com o conceito de tato psicológico, Ferenczi ilumina uma região que até então era deixada às idiossincrasias de cada analista. Também volta a valorizar a análise do analista, bem como o controle da relação contratransferencial. Ao seguir esse conselho técnico, tornase fundamental para o analista o acesso a seus próprios afetos, pois a falta deles está diretamente ligada a um aumento da resistência na análise. Ao localizarmos essa fala de Ferenczi num momento em que ele abandona a sua técnica ativa, podemos reconhecer nesses “conselhos” a possibilidade técnica desenvolvida por ele para evitar os problemas que teve de enfrentar em suas experiências da técnica ativa.

Durante os anos seguintes, até sua morte, Ferenczi se dedicou a uma outra vertente de suas experiências técnicas, que têm dois pontos bastante relevantes que iremos abordar: o princípio de relaxamento e a hipocrisia do analista.

Em sua fala sobre a elasticidade, Ferenczi já deixava entrever uma postura mais benevolente em relação ao analisando, que diminuiria a possibilidade de resistência - em oposição às grandes resistências que encontrou, com a posição mais autoritária presente no uso na técnica ativa. É justamente às possibilidades dessa postura mais benevolente que Ferenczi dedica seus anos seguintes. Essa postura mais benevolente teve por base um princípio diferente e oposto ao princípio de frustração da técnica ativa: o princípio de relaxamento (ou princípio de realização ${ }^{20}$ ). Esse princípio refere-se ao quanto a análise deriva também de experiências de liberdade e conforto. Ferenczi constatou que nem todos os avanços que conseguira com a técnica ativa, ou mesmo com a técnica clássica, eram frutos do aumento de tensão pulsional; alguns dos avanços eram resultados de uma boa experiência vivida na análise, da confiança depositada na franqueza do analista, do relaxamento promovido pela segurança do setting analítico. Essa postura, mais próxima da mãe benevolente, fez com que Ferenczi construísse uma crítica bastante rigorosa ao que chamou

\footnotetext{
${ }^{20}$ Para maiores detalhes, cf. Princípio de relaxamento e neocatarse, in Obras completas, vol. IV.
} 
de hipocrisia profissional e permitiu que avançasse bastante na discussão em torno do estatuto do trauma. ${ }^{21}$

A hipocrisia profissional consiste na postura do analista que o faz esconder do paciente seus afetos. Tal postura traria grandes malefícios ao processo de análise:

\begin{abstract}
Cheguei pouco a pouco à conviç̧ão de que os pacientes percebem com muita sutileza os desejos, as tendências, os humores, as simpatias e antipatias do analista, mesmo quando este está inteiramente inconsciente disso. Em vez de contradizer o analista, de acusá-lo de fracasso ou de cometer erros, os pacientes identificam-se com ele [FERENCZI, 1933/1992, p.98].
\end{abstract}

Podemos retornar agora à questão que deixamos em aberto no final da discussão sobre a contratransferência e retornar ao nosso problema considerando o contexto institucional. Em 1918, Ferenczi já percebia os riscos da contratransferência para o desenvolvimento da transferência e, conseqüentemente, da análise, mas propunha que um rigoroso controle dos afetos, conquistados pela análise do analista e pela experiência clínica, seria capaz de fortalecer um mediador pré-consciente que daria conta desses problemas. Em 1933, depois da bagagem acumulada com suas experiências técnicas, percebeu que o problema do controle dos afetos é mais complexo e, apesar das recomendações anteriores terem ganhado ainda mais importância para o trabalho técnico da psicanálise, elas não seriam suficientes para dar conta do problema. O principal impasse estava na descoberta de Ferenczi de que o analisando agredido por um erro cometido pelo analista tende à identificação como forma de defesa. ${ }^{22} \mathrm{O}$ analisando, não se sentindo autorizado a contradizer seu analista, acaba sofrendo na análise a reedição de uma situação traumática: não tendo acesso à linguagem de seu agressor - no caso, o analista -, ele é forçado a tomar a situação angustiante como natural, recalcando-a e identificando-se com ela.

\footnotetext{
${ }^{21}$ Cf. Confusão de língua entre os adultos e a criança, in Obras completas, vol. IV.

${ }^{22}$ Ferenczi (1933/1992).
} 
Para evitar tal situação, Ferenczi propõe, como medida técnica, que se renuncie a essa “hipocrisia profissional” e se dividam com o analisando os incômodos e preocupações vividas em análise:

\begin{abstract}
A situação analítica, essa fria reserva, a hipocrisia profissional e a antipatia a respeito do paciente que se dissimula por trás dela, e que o doente sente com todos os seus membros, não difere essencialmente do estado que outrora, ou seja, na infância, o fez adoecer. [...] Mas a capacidade de admitir os nossos erros e de renunciar a eles, a autorização das críticas, fazem-nos ganhar a confiança do paciente. Essa confiança é aquele algo que estabelece o contraste entre o presente e um passado insuportável e traumatogênico [FERENCZI, 1928/1992, p.100].
\end{abstract}

Os três pontos que trabalhamos: a elasticidade da técnica, o princípio de relaxamento e a hipocrisia profissional, apresentam alternativas para o problema detectado pela técnica ativa. Temos, por eles, mais perspectivas técnicas para lidar com a resistência. Por outro lado, deparamo-nos com outro problema, a identificação do analisando com aquele que o agride.

Do ponto de vista da resistência, enumeramos antes que seus fatores se apresentavam: 1) na resistência do paciente, ligada à manutenção de fantasias onipotentes depositadas na figura do analista/mestre; 2) na resistência do analista, também entregue às fantasias de onipotência, atuando com medidas sádicas e autoritárias. Quando inserimos a elasticidade e a honestidade do analista como recursos técnicos para a atuação na instituição, abrimos boas possibilidades de lidar com as resistências supracitadas. A admissão dos erros, bem como consideração mais rigorosa do saber do analisando frente ao seu processo, vem apresentar forte contraste às fantasias de onipotência presentes na relação entre transferência e contratransferência. Ao mesmo tempo, essas medidas técnicas rompem com a relação instituída entre especialista e leigo, ruptura que pode fazer emergir o sujeito para a análise.

Já em relação a nosso outro problema: a identificação com o agente agressor, nos deparamos com um mecanismo primário que serve também à adaptação aos grupos (FREUD, 1921/1976; KAËS, 1997). Dedicaremos uma parte de nosso próximo capítulo à importância das identificações para a existência das instituições e dos conjuntos. Entretanto, desde já, 
percebemos que os estudos de Ferenczi sobre a hipocrisia profissional e o princípio de relaxamento nos auxiliam a revelar que a instituição possui um grande potencial patologizante para o sujeito. Se já é difícil ao sujeito enfrentar o analista quando este comete seus erros, mais difícil se torna fazê-lo quando ele está associado transferencialmente a uma instituição. O que nos leva ao seguinte questionamento, que desta vez nasce para permanecer em suspenso até o final: apesar das possibilidades técnicas de tentar estabelecer a análise nas instituições, algumas delas levantadas neste texto, seria esse um lugar recomendável para a análise?

Para encerrarmos nosso percurso acerca das contrapartidas do analista na situação analítica, retornaremos agora à questão que deixamos em suspenso acerca do controle da contratransferência.

\subsection{A CONTRATRANSFERÊNCIA COMO INSTRUMENTO DO ANALISTA}

Em nossas considerações iniciais sobre a contratransferência abordamos apenas a parcela descritiva do fenômeno, aquilo que Ferenczi pôde observar antes de suas experiências técnicas. Ressaltamos os aspectos da comunicação inconsciente entre analista e analisando e a importância do controle, a partir do pré-consciente, dos afetos contratransferenciais do analista. Após nossas considerações acerca das experiências técnicas de Ferenczi, nas quais ele explorou outras alternativas para a posição do analista na transferência, devemos contar que a contratransferência pode ser muito mais do que algo a ser controlado, podendo ser um indicador importante para as diversas possibilidades de intervenção do psicanalista. Discriminemos melhor a situação contratransferencial. Winnicott (1947/2000, p. 278) afirma que os fenômenos contratransferenciais podem ser classificados da seguinte maneira:

1. Anormalidade nos sentimentos contratransferenciais, e relacionamentos e identificações padronizados e reprimidos do analista. [...] 
2. As identificações e tendências oriundas da experiência e do desenvolvimento pessoal do analista, que fornecem as bases positivas do seu trabalho analítico e tornam esse trabalho diferente dos de outros analistas.

3. [...] a contratransferência verdadeiramente objetiva ou, se isto for difícil, o amor e o ódio do analista em reação à personalidade e ao comportamento real do paciente, com base numa observação objetiva.

Acerca do primeiro tipo de contratransferência continuamos no registro do controle pela análise do analista. Sobre o segundo tópico de classificação já encontramos uma diferença: a contratransferência como aquilo que fala da singularidade do analista fazer sua análise. Quanto a essa expressão da contratransferência nossa atenção fica apenas no reconhecimento e autorização do analista em expressar sua singularidade na situação analítica sem romper o enquadre que produz a transferência. Esse mesmo reconhecimento deve ocorrer em relação ao contexto institucional, um reconhecimento da singularidade do analista se adaptar à situação institucional sem a necessidade de um protocolo de ações a serem desempenhadas. Alice e Michael Balint (1939/2002, p. 13) compreendem a expressão destas singularidades da seguinte maneira:

Uma das fontes principais da técnica individual do analista é a transferência de emoções. Ou seja, nossa técnica e nosso comportamento analítico também têm importante valor econômico, pois constituem uma forma bem adaptada, bem racionalizada, sublimada de aliviar tensões, especialmente aquelas que surgem em nós quando lidamos com nossos pacientes.

A atuação contratransferencial nas singularidades do enquadre ou nas posturas do analista quanto às falas ou tempo de interpretação, desde que respeitada a primeira condição de controle pela análise do analista, servem principalmente para o bom funcionamento econômico da situação transferencial.

O que mais nos interessa, no entanto, quanto à classificação das contratransferências é a do terceiro tipo, que não só oferece um complemento da cena transferencial por parte do analista, como se constitui em um dispositivo técnico para que tenhamos uma via de acesso 
privilegiado par ao entendimento da cena transferencial. Winnicott (1947/2000, p.279) expõe a importância desse uso da contratransferência nos seguintes termos:

Uma das tarefas mais importantes na análise de qualquer paciente é a de manter a objetividade em relação a tudo aquilo que o paciente traz, e um caso especial desse tema é a necessidade de o analista ser capaz de odiar o paciente objetivamente.

Essa compreensão do fenômeno contratransferencial nos permite ver que aquilo que os afetos do analista da mesma forma que podem levá-lo aos piores erros, fazendo-o atuar sobre o paciente seus próprios sintomas, é também a única via possível do que poderíamos chamar de uma objetividade analítica. Heimann (1949/2002, p. 18), também defendia a contratransferência como um dispositivo técnico importante para a psicanálise:

Do ponto de vista que sustento, a contratransferência do analista não é apenas parte essencial da relação analítica, mas é também criação do paciente, é também uma parte de sua personalidade. [...] A meu ver, a demanda de Freud de que o analista reconheça e domine sua contratransferência não leva à conclusão de que esta seja um fator perturbador e que o analista deva tornar-se insensível e imparcial. E sim que ele deve usar sua resposta emocional como uma chave para o inconsciente do paciente.

A contratransferência como chave ao inconsciente do paciente, em nosso contexto institucional pode oferecer-nos também uma chave para as fantasias ligadas à instituição. Chegamos aqui não apenas a um retrato da situação transferencial que encontramos nas instituições como também encontramos o recurso técnico que nos servirá de lanterna para a análise dos casos ocorridos no interior das instituições.

\subsection{TRANSFERÊNCIA, ANÁLISE E INSTITUIÇÃO}

A título de conclusão do capítulo, para que o leitor possa visualizar mais claramente o que pudemos acumular até aqui, apresentaremos um quadro geral sobre a inserção do 
institucional na situação analítica, nossas considerações sobre essa articulação e sobre a transferência.

A primeira das possibilidades de inserção se baseia no entendimento da transferência como um mecanismo de introjeção, postulado por Ferenczi. Dentro desta concepção mais abrangente da transferência, que se refere a uma característica deste fenômeno que se observa indiscriminadamente tanto na situação analítica como em qualquer outra situação da vida, a instituição é introjetada no ego, reduzida em sua complexidade geradora de tensão, convertendo-se em mero objeto de realização egóica. Frente à angústia do estranho, tratar-seia da possibilidade do ego dar conta deste objeto pela integração a si.

As outras possibilidades de inserção contam com a elaboração de nosso conceito de transferência, construído a partir das contribuições de Laplanche, que a postula como uma formação inconsciente passível de produção, na qual se daria a realização e produção do desejo pelo rearranjo de pulsões. Essa concepção de transferência destaca as características que fazem dela um fenômeno potente no interior da clínica psicanalítica, características que a fazem fenômeno ímpar no desenvolvimento do processo analítico. A possibilidade do rearranjo pulsional é condicionada tanto por fatores internos - relacionados ao grau de intensidade do conflito pulsional - quanto por fatores externos - relacionados à possibilidade de criar um ambiente de isolamento e proteção frente a estímulos externos (situação analítica). A partir desse conceito, verificamos três outras possibilidades de inserção do institucional:

a) Como cena continente e produtora da transferência: a continência e a produção do conflito pulsional pela instituição se dá pela organização fantasmática envolvida na transferência (de complexos parentais) que ela é capaz de sustentar e favorecer. Em relação à continência do conflito pulsional, esta interpenetração se dá indiretamente, pois se refere a um maior poder de influência investido no analista para que ele auxilie o ego do sujeito a dar conta das pulsões. Em relação à produção, a associação é direta, 
pois a transferência, produzida pelo favorecimento da cena, encontra na instituição as condições necessárias e suficientes para se estabelecer (isolamento do mundo e posições de assimetria em relação a um saber sexual). Isso ocorre mesmo quando não se trata de uma situação analítica, o que resulta numa ampliação dos efeitos transferenciais de influência no caso da associação de ambas as condições.

b) Como matriz dos sentidos que permitem a realização pulsional e fantasmática: pela relação com os papéis instituídos (médico, professor), essa inserção institucional surge com mais clareza do que a própria possibilidade de análise; aponta para um caminho da técnica em que o analista deve reconhecer primeiramente suas próprias limitações frente à influência institucional, para que possa assim caminhar no sentido da análise.

c) Como elemento constituinte da realidade psíquica: essa inserção remonta à origem fantasmática da transferência e não à sua manifestação. Exploraremos melhor essa inserção no próximo capítulo, em que nos dedicaremos a algumas relações entre o sujeito e o institucional que extrapolam o contexto analítico.

Essas inserções do institucional, lado a lado, suscitam algumas reflexões sobre a prática dos atendimentos. Freud nos ajuda a explicitar uma conseqüência:

Longos debates preliminares antes do início do tratamento analítico, tratamento
prévio por outro método e também conhecimento anterior entre médico e o
paciente que deve ser analisado, têm conseqüências desvantajosas especiais,
para as quais se tem de estar preparado. Elas resultam em o paciente encontrar o
médico com uma atitude transferencial já estabelecida e que o médico deve, em
primeiro lugar, revelar lentamente, em vez de ter a oportunidade de observar o
crescimento e o desenvolvimento da transferência desde o início. Desta maneira,
o paciente obtém sobre nós uma dianteira temporária, que não lhe
concederíamos voluntariamente no tratamento [FREUD, 1913a/1976, p.67].

A desvantagem de uma relação prévia e que o analista não pôde acompanhar é condição inerente a qualquer atendimento realizado no contexto de uma instituição maior em que se insira a psicanálise. Não se trata do único cuidado técnico - poderíamos discutir também a tentação de ceder às tendências sugestivas, a possibilidade de utilizar essa 
influência, a dificuldade de identificar a transferência frente à multiplicidade de suportes transferenciais, entre outros - mas serve de ilustração de como esses elementos nos encaminham para uma discussão mais pormenorizada da técnica psicanalítica e sobre sua flexibilidade para dar conta desse contexto. Frente a estas dificuldades elencamos as contrapartidas do analista frente à situação transferencial e suas possibilidades técnicas. Destacamos também a contratransferência como o principal instrumento norteador para que o psicanalista possa manter sua objetividade. Para o quarto capítulo, na análise dos casos, poderemos então contar com a contratransferência como fiadora de nossa análise.

Reunimos até aqui elementos suficientes para uma boa compreensão dos fenômenos transferenciais, que nos auxiliaram na descrição da situação analítica institucional e nos auxiliarão na articulação desta com uma prática, nosso objetivo final. Encontramos também nessa primeira discussão outros elementos, referentes à noção de realidade psíquica e a técnica psicanalítica, que deverão ser trabalhados na direção de nosso objetivo. Para finalizar, uma síntese de Lagache (1951/1990, p.132-3) sobre o que pudemos reunir:

O desenvolvimento da transferência é produzido pela interação entre a disposição para transferir e o ambiente psicanalítico. [...] poder-se-ia definir o campo psicanalítico pelas interações entre o paciente e o ambiente psicanalítico, vinculando a este último a pessoa e o papel do psicanalista [...] o que não implica, em absoluto, uma modificação do papel por parte do analista mas, outrossim, uma conscientização mais completa da significação e da influência dos "traços" de seu papel [grifo nosso]. 


\title{
3. A Instituição, a organização e o sujeito
}

\author{
“A castração pode ser definida como a descoberta, no registro identificatório, de que não \\ ocupamos jamais o lugar que acreditávamos nosso e que inversamente já estávamos destinados a \\ ocupar um lugar no qual não poderíamos ainda encontrar-nos." \\ Aulagnier, A violência da interpretação, p.158.
}

As relações entre o sujeito e a esfera institucional, que se apresentam na transferência, ecoam uma vinculação mais primitiva entre ambos. Discriminamos dentro da situação analítica, por via de um estudo da transferência, as possibilidades dessa relação: introjeção ao ego, continência e produção da transferência, suporte de realização transferencial. Todas se apóiam sobre uma relação entre sujeito e instituição que precede a transferência, o que nos aponta à quarta via de inserção do institucional na cena analítica: sua participação na constituição da realidade psíquica do sujeito. Neste caso, podemos considerar que não se configura uma outra via, mas sim se evidencia a importância de uma análise da relação entre sujeito e instituição, que sustenta a possibilidade de uma situação analítica, bem como a extrapola.

Nosso trabalho será o de esclarecer qual conceito de instituição podemos construir a partir do referencial psicanalítico, explorar quais laços ligam o sujeito a essas instituições e como eles aparecem na constituição de sua própria subjetividade. Nosso intuito é o de localizar como esta relação entre sujeito e instituição favorece uma determinada cena analítica, bem como constituem elementos não transferenciais - vinculação do sujeito às instituições, tensão entre a instituição psicanalítica e a instituição provedora do serviço, vinculação entre analista e analisando pela via institucional e não transferencial - a serem trabalhados pelo analista, no analisando e em si mesmo.

A necessidade de uma exploração das relações entre sujeito e instituição, quando não circunscritas pela situação analítica, lança-nos a um campo bastante abrangente da literatura 
psicanalítica, que tem como objeto os grupos, as instituições e a cultura. Temos a dupla tarefa de construir um conceito de instituição e traçar um recorte que cumpra essa tarefa sem nos tomar o trabalho inteiro. Procuraremos ter como fiador nessa exploração o sujeito singular, mesmo quando, em alguns momentos, este tende a se diluir dentro do coletivo institucional.

\subsection{INSTITUIÇÃO E ORGANIZAÇÃO}

Até o momento, nos foi suficiente tratar de uma instituição em que a prática do atendimento pelo psicanalista fosse contemplada, porém não restrita a ela. Desta forma esperamos que o leitor tenha em mente, por instituição, tanto sua concretude organizacional quanto os sentidos que orientam sua prática. Para o estudo da situação analítica e da transferência (tema do capítulo anterior), essa imagem, um tanto genérica, nos bastava, pois nosso foco era localizar, a partir do setting analítico, em quais pontos este campo heterogêneo se fazia perceber. Entretanto, para a investigação das relações diretas entre sujeito e instituição, essa definição necessitará de alguns desenvolvimentos.

Estamos cientes de que o uso do conceito de instituição evoca pelo menos dois significados distintos: um deles refere-se a manifestações humanas na cultura, no que tange à sua organização social (por exemplo, os laços parentais, a religião, a política, a economia), que circunscreve uma cadeia de sentidos para as ações, delimita padrões de conduta esperados (e ideais) e significa uma série de construções humanas - neste aspecto, a instituição se caracteriza principalmente como uma esfera simbólica e/ou imaginária; outro significado de instituição se refere a organizações hierárquicas com funções específicas, estabelecidas num espaço físico delimitado, regido por um código de regras e normas que estipulam punições e recompensas (por exemplo, a escola de meu filho, a indústria onde trabalho, a igreja que freqüento, o presídio em que estou preso) - temos aqui a instituição caracterizada como uma dimensão concreta. Temos, para discriminar esta segunda concepção, também o nome de 
organização ${ }^{23}$. Trata-se de uma distinção que nos auxilia a conquistar uma maior clareza do objeto em questão.

Toda instituição só pode ser apreendida pelo sujeito a partir de outros sujeitos, a partir de um conjunto e principalmente a partir das organizações. Entretanto, a manifestação concreta num espaço, tempo, conjunto de regras e conjunto de sujeitos, que chamamos de organização, não coincide perfeitamente com as instituições que sustentam seu sentido, que legitimam sua existência no campo social. Observamos mais claramente este fenômeno quando, por exemplo, uma determinada escola tem ações antipedagógicas, ou um hospital, ações antiterapêuticas. Encontramos a seguinte abordagem do problema em Bleger (1970/2003, p.115):

Em todas elas [organizações] os objetivos explícitos para os quais foram criadas correm sempre o risco de passar a um segundo plano, passando ao primeiro plano a perpetuação da organização como tal. [...] Em outros termos, diria que o grupo se burocratizou, entendendo por burocracia a organização na qual os meios se transformam em fins e se deixa de lado o fato de se ter recorrido aos meios para conseguir determinados objetivos ou fins.

Quando um hospital começa a tomar atitudes antiterapêuticas em relação a seus pacientes, podemos notar uma contradição em relação aos seus “objetivos ou fins determinados” socialmente - tratar e curar as pessoas. Essa contradição, indicadora de um mau funcionamento organizacional em relação à sua função social, explicita o atravessamento de outras lógicas em seu funcionamento. A complexidade de uma organização contempla interesses psíquicos, psicológicos, políticos, culturais e econômicos, que podem levá-la a não

${ }^{23}$ Cf. BLEGER, 1970/2003. Também BAREMBLITT (2002) e ENRIQUEZ (1991) fazem diferenciações semelhantes. Porém, o primeiro discrimina ainda mais os elementos envolvidos em organizações de diversas complexidades, o que é interessante para o estudo específico das organizações, mas não nos interessa no momento, e o segundo lança mão do conceito de estabelecimento no lugar de organização, mas trata-se de um conceito mais restrito que o que Bleger nos apresenta e por isso optamos por organização. 
cumprir suas funções sociais. Quando optamos por um recorte sobre a dimensão psíquica dos fenômenos, esta passou a ser nossa lente de referência frente à heterogeneidade de interesses: estamos interessados em como o sujeito é afetado pela dinâmica inconsciente dos processos organizacionais e institucionais. A partir dessa lente, que passa pelo funcionamento do sujeito e dos sujeitos em relação, as contradições, os paradoxos, deixam de se apresentar como rupturas, que demarcariam campos diferentes de uma análise institucional, para se apresentarem como material de uma dimensão que particularmente nos interessa: o que na instituição mantém os sujeitos reunidos e organizados em um mesmo sentido. Dentro dessa perspectiva pela própria existência das contradições é possível encontrar o sujeito, ou seja, nas contradições entre organização e instituição não encontramos um problema, mas nosso caminho.

Para nos auxiliar em dois outros esclarecimentos, uma passagem de Kaës (2002, p.20):

\begin{abstract}
A instituição, com efeito, vincula, reúne e gerencia formações e processos heterogêneos: sociais, políticos, culturais, econômicos e psíquicos. Portanto, lógicas diferentes funcionam nos seus espaços se intercomunicando e interferindo uns nos outros. Por isso, podem imiscuir-se e prevalecer na lógica social da instituição questões e soluções pertinentes ao nível da lógica psíquica. Deve considerar-se ainda que a instituição é o lugar de uma dupla relação: do sujeito singular com a instituição e do conjunto de sujeitos vinculados pela e na instituição.
\end{abstract}

Apesar de nosso foco ser a dimensão psíquica do fenômeno, é impossível isolar o fenômeno psíquico, devido à interferência mútua entre as diferentes lógicas que atravessam o campo organizacional. Nosso recorte, portanto, que não pretende dar conta do fenômeno total das relações institucionais, por vezes encontrará a influência de outros processos, mas apenas quando estes se apresentarem como indissociáveis da cena psíquica.

O segundo aspecto que queremos ressaltar é que, ao tratarmos das relações que constituem e extrapolam a situação analítica, nossa exploração deve levar em consideração que o sujeito (neste caso, tanto o analisando quanto o analista) está envolvido nesta “dupla 
relação” que assinala Kaës. Estruturaremos este capítulo em função dessa dupla relação, de modo a compreender sua natureza, bem como de que maneira elas se comunicam.

Apesar dos esclarecimentos que a separação entre processos organizacionais e institucionais nos oferece, nosso interesse em seu uso é apenas inicial. Isto porque esta separação deverá ainda ser questionada a partir do mesmo referencial de onde questionamos o conceito de transferência: da óptica do sujeito do inconsciente. Nosso interesse nesta distinção não é a de tomá-la como atalho para nosso conceito de instituição, mas sim de questioná-la frente à psicanálise para, a partir deste confronto, construir nosso conceito de instituição.

\subsubsection{RETORNO A ORIGEM: DA HORDA AO TOTEMISMO}

Retornaremos uma vez mais a Freud para encontrara as bases de nossa discussão. Não encontramos na obra freudiana uma preocupação específica em relação às instituições ou organizações, ou mesmo uma preocupação em discriminar esses dois termos. Entretanto encontramos nela uma preocupação em compreender o fenômeno das massas (Freud, 1921/1976), conceito mais abrangente, que nos permite pensar tanto organizações, quanto instituições, mas também grupos efêmeros e quaisquer outras relações sociais. Como os aponta Roudinesco (1998, p. 613):

\footnotetext{
A intenção sociológica e política desse ensaio, no qual Freud se refere explicitamente à concepção aristotélica do homem como animal político, tem sido freqüentemente encoberta por traduções aproximativas. James Strachey, ao traduzir o termo alemão Massen por group [grupo], em vez de mass [massa] [...] optou por uma concepção reducionista do social [...], segundo a qual o grupo constitui o modelo, reduzido ou experimental, da sociedade. As diversas traduções francesas não foram mais precisas. Até 1981, privilegiou-se a dimensão quantitativa, ainda que refutada por Freud, falando-se em psicologia coletiva. Esse foi um travestimento ainda mais digno de nota, na medida em que, para traduzir o termo francês foule [...] Freud preferiu o termo alemão Massen à palavra Menge, assim privilegiando a conotação política [em 1991 a tradução francesa recuperou o termo masses em conformidade com a opção de Freud].
} 
A intenção de Freud ao se questionar sobre a psicologia das massas e não dos grupos, organizações ou instituições, como bem aponta Roudinesco, tinha como foco compreender a relação social como uma relação que diferia em qualidade - uma qualidade eminentemente política - e não em quantidade da psicologia individual. Para delimitarmos nossos conceitos, tentaremos seguir este mesmo princípio freudiano. Retornemos, então, às origens, àquilo que possibilitou não só as massas, mas a própria cultura, ao ato que está na origem de quaisquer instituições ou organizações sociais.

Certo dia, os irmãos que tinham sido expulsos retornaram juntos, mataram e devoraram o pai, colocando assim um fim à horda patriarcal. Unidos, tiveram a coragem de fazê-lo e foram bem sucedidos no que lhes teria sido impossível fazer individualmente. [...] Selvagens canibais como eram, não é preciso dizer que não apenas matavam, mas também devoravam a vítima. $\mathrm{O}$ violento pai primevo fora sem dúvida o temido e invejado modelo de cada um do grupo de irmãos: e, pelo ato de devorá-lo, realizavam a identificação com ele, cada um deles adquirindo uma parte de sua força. A refeição totêmica, que é talvez o mais antigo festival da humanidade, seria assim uma repetição, e uma comemoração desse ato memorável e criminoso, que foi o começo de tantas coisas: da organização social, das restrições morais e da religião. [FREUD, 1913b/1974, p. 170, grifo nosso]

Para analisarmos a hipótese freudiana do parricídio, na qual se localizaria o fundamento psíquico da constituição da cultura, destacaremos dois momentos: a organização que possibilitou o assassinato e seu desfecho canibal.

A situação original de horda patriarcal a qual Freud se refere, consistiria em agrupamentos humanos relativamente pequenos, liderados por um macho mais forte e mais velho, que impediria a promiscuidade sexual dentro do grupo, monopolizando para si as fêmeas. Um macho mais novo, quando passavam a rivalizar com este chefe pelas fêmeas do grupo, ou o derrotava pela força e tornava-se o novo chefe da horda ou acabava expulso, sendo obrigado a procurar uma nova horda pela qual batalhar, repetindo, assim o ciclo. Esse quadro baseia-se na hipótese de que a princípio o comportamento dos agrupamentos humanos pouco ou nada se diferenciaria dos agrupamentos de símios superiores. Eis que em dado momento da história algo acontece: os filhos expulsos pelo chefe da horda, ao invés de 
seguirem, sozinhos, seus caminhos em busca de novas hordas, retornam juntos para derrotálo. "Unidos, tiveram a coragem de fazê-lo e foram bem sucedidos no que lhes teria sido impossível fazer individualmente”. Nosso destaque para essa passagem está no fato de que neste ato encontra-se a primeira possibilidade de uma coletividade. A horda, apesar de ser um agrupamento, responde apenas as vontades de seu chefe; é uma extensão dele. Este grupo de filhos expulsos, no entanto tem em si algo de diferente: eles não estão agrupados, mas se reúnem, necessitam um do outro para a tarefa que se propõem a fazer. E o que está na base dessa primeira reunião? O temor e o ódio ao chefe da horda. O temor os reúne e o ódio os impele a uma ação conjunta. São ódio e medo as fontes da primeira vinculação entre os homens, capaz fazê-los se reconhecer como grupo, de fazer dos filhos expulsos, irmãos. E é o assassinato seu primeiro feito coletivo.

Voltemos nossa atenção agora ao segundo momento deste feito: "pelo ato de devorálo, realizavam a identificação com ele, cada um deles adquirindo uma parte de sua força”. Pelo ato de devorar ao chefe, os irmãos, que se reuniram pelo ódio e pelo medo, faziam sua primeira partilha: do poder que antes pertencia somente ao chefe agora todos tomavam parte.

Pelo ato de incorporação, que se segue ao assassinato, sela-se de forma durável a
existência do grupo. O banquete coletivo, durante o qual são incorporados as
virtudes e os poderes daquele que imagina possuí-los, é o momento em que o
grupo vive um sentimento coletivo, no transe e na excitação, em que cada um
pode ver no olhar do outro o mesmo ódio e o mesmo contentamento, se
identificar ao outro na medida em que este se torna seu semelhante pela
incorporação de uma potência, de uma carne e de um sangue único. O sangue do
onipotente corre na veia de todos. [ENRIQUEZ, 1983b/1991, p. 32]

A refeição coletiva da carne e do sangue do chefe da horda permite simultaneamente que se estabeleça uma identificação entre cada um e o chefe morto e de todos entre si. Se o ódio e o medo são a base da primeira reunião, é esta dupla identificação o alicerce de sustentação do grupo. Temos então na base da percepção de uma intersubjetividade, na base de uma assimilação do coletivo, o ódio, o medo e as identificações. 
Vejamos agora outro desdobramento do assassinato: a transformação do chefe da horda em pai. Centrando-se no ódio que reuniu os irmãos Enriquez (1983b/1991, p.31) apresenta-nos a seguinte compreensão da obra freudiana:

Eis então o golpe de mestre de Freud: se é o ódio que transforma os seres submissos em irmãos, é seu assassinato que transforma o chefe da horda em pai. Logo, não existe pai, se esse, que pode ser assim investido, não somente possui as mulheres, mas ainda, e, sobretudo, é o objeto de um desejo de morte. O pai, enquanto tal, não existe a não ser morto realmente ou simbolicamente; o que nos leva a uma noção fundamental: o pai não existe a não ser como ser mítico. [...] o pai, em sua função mítica, é aquele que provoca reverência, terror e amor ao mesmo tempo, o pai é aquele que sufoca, castra e que deve ser morto ou, no mínimo, vencido; ele é, além disso, o portador e depositário das proibições. [grifo nosso]

Morto, o odiado chefe da horda torna-se pai. Como pai desperta não apenas o terror, mas também o amor, a culpa, e, conseqüentemente, a ambivalência de sentimentos que sua presença aterradora, antes, tornava impossível. Destaquemos o lugar especial em que se configura esta função paterna. A relação com o pai, por sua incorporação, é uma relação interna, do sujeito com o pai dentro de si, com seus sentimentos ambivalentes, seu ódio, seu medo e sua culpa; pela identificação do sujeito com o pai, este se torna “portador e depositário das proibições”; é pelo pai internalizado e pela ambivalência de sentimentos em relação a ele que o sujeito pode conceber e lidar com as proibições que resultarão do advento do social. É nessa relação internalizada com as restrições advindas do social que encontramos as bases da relação do sujeito do inconsciente com as instituições sociais. Caminhemos agora para os desdobramentos do assassinato: a comunidade de irmãos e o totemismo. Eis o que nos diz Freud (1913b/1974, p. 174-5)

\footnotetext{
A horda patriarcal foi substituída, em primeira instância, pela horda fraterna, cuja existência era assegurada pelo laço consangüíneo. A sociedade estava agora baseada na cumplicidade do crime comum; a religião baseava-se no sentimento de culpa e no remorso a ele ligado; enquanto que a moralidade fundamentava-se parte nas exigências dessa sociedade e parte na penitência exigida pelo sentimento de culpa.
}

Se o terror regia a horda patriarcal a cumplicidade, o remorso e a culpa, assegurados pelos laços de sangue, estabelecem o funcionamento da horda fraterna. Uma horda penitente, 
que a um só tempo teve que encontrar mecanismos para lidar com um outro que não podia ser eliminado (os irmãos) e com a culpa de perceber, pelo pai morto, sentimentos antes insuspeitáveis. Continuemos com Freud (1913b/1974, p. 171-2)

\begin{abstract}
A fim de que estas últimas conseqüências possam parecer plausíveis [...] precisamos apenas supor que a tumultuosa malta de irmãos estava cheia dos mesmos sentimentos contraditórios que podemos perceber em ação nos complexos-pai ambivalentes de nossos filhos e de nossos pacientes neuróticos. [..] O pai morto tornou-se mais forte do que o fora vivo - pois os acontecimentos tomaram o curso que com tanta freqüência os vemos tomar nos assuntos humanos ainda hoje. O que até então fora interdito por sua existência real foi doravante proibido pelos próprios filhos, de acordo com o procedimento psicológico que nos é tão familiar nas psicanálises, sob o nome de 'obediência adiada'. Anularam o próprio ato proibindo a morte do totem, o substituto do pai; e renunciaram aos seus frutos abrindo mão da reivindicação às mulheres que agora tinham sido libertadas. Criaram assim, do sentimento de culpa filial, os dois tabus fundamentais do totemismo, que, por essa própria razão, corresponderam inevitavelmente aos dois desejos reprimidos do complexo de Édipo. Quem quer que infrinja esses tabus torna-se culpado dos dois únicos crimes pelos quais a sociedade primitiva se interessava.
\end{abstract}

Do sentimento de culpa organizar-se, então, a sociedade totêmica, tendo como seus dois principais tabus a proibição da morte do totem (representante do pai), e a proibição do incesto. Nesta, que talvez seja a primeira forma de organização social, ainda não podemos distinguir instituições e organizações. Os tabus e o totem são ao mesmo tempo expressões concretas e elaborações simbólica do conflito do sujeito em lidar com a penitência pelo assassinato: a vida regulada por restrições de conduta. Entretanto consideramos que estes conflitos, mesmo em sua concretude, aproximam-se mais com as relações do sujeito que irão se desdobrar nas instituições, do que com o funcionamento das organizações. Isto porque se tomarmos que as instituições referem-se à conduta do sujeito em relação à comunidade humana em seu sentido mais amplo, a normas que regulam não apenas uma situação circunscrita, mas apontam os parâmetros de pertencimento àquela comunidade (o que inclusive dão sentido as regras organizacionais), encontramos na sociedade totêmica as mesmas exigências que nos fazem as instituições sob uma forma mais direta da relação com o totem e do submetimento aos tabus. Por uma diferença de complexidade na organização 
social e no psiquismo dos sujeitos, o que em nossa cultura realizamos a partir de um imaginário social compartilhado e sob a forma das instituições sociais, podemos compreender que a sociedade totêmica realizava num registro simbólico compartilhado, sob a forma dos rituais $^{24}$ e dos tabus (o que por sua vez pode ser compreendido como um avanço em relação à horda, onde os conflitos só podiam ser resolvidos por atos).

Vejamos agora na visão de Freud (1913b/1974, p. 172) os dois tabus primordiais da sociedade totêmica um pouco mais de perto:

Os dois tabus do totemismo com que a moralidade humana teve o seu começo não estão psicologicamente no mesmo nível. O primeiro deles, a lei que protege o animal totêmico, fundamenta-se inteiramente em motivos emocionais: o pai fora realmente eliminado e, em nenhum sentido real, o ato podia ser desfeito. Mas a segunda norma, a proibição do incesto, tem também uma poderosa base prática. Os desejos sexuais não unem os homens, mas os dividem. Embora os irmãos se tivessem reunido em grupo para derrotar o pai, todos eram rivais uns dos outros em relação às mulheres. [...] A nova organização terminaria numa luta de todos contra todos, pois nenhum deles tinha força tão predominante a ponto de ser capaz de assumir o lugar do pai com êxito. Assim, os irmãos não tiveram outra alternativa, se queriam viver juntos talvez somente depois de terem passado por muitas crises perigosas - , do que instituir a lei contra o incesto, pela qual todos, de igual modo, renunciavam às mulheres que desejavam e que tinham sido o motivo principal para se livrarem do pai. [grifo nosso]

Afirmamos anteriormente que a sociedade totêmica experimentava sob a forma simbólica e compartilhada de seus rituais e tabus aquilo que em nossa sociedade experimentamos em nosso contato com as instituições e organizações, ou seja, ambos teriam por função mediar as relações do sujeito no campo social. Dentro dessa perspectiva, encontramos nessa passagem de Totem e Tabu um dado significativo para diferenciar a internalização das normas do social: os tabus não estão psicologicamente no mesmo nível.

O porquê dessa diferença de nível psicológico está relacionado ao referencial de ambos os tabus. Enquanto a proteção ao animal totêmico diz respeito diretamente a uma

\footnotetext{
${ }^{24}$ Devemos ter em mente que além do rigor dos tabus e das regras encontramos também na constituição do laço social os festivais: "Um festival é um excesso permitido, ou melhor, obrigatório, a ruptura solene de uma proibição. Não é que os homens cometam os excessos porque se sentem felizes em conseqüência de alguma injunção que receberam. O caso é que o excesso faz parte da essência do festival; o sentimento festivo é produzido pela liberdade de fazer o que via de regra é proibido." (FREUD, 1913b/1974)
} 
relação com o pai morto, à culpa inerente ao assassinato, e desta maneira a uma relação direta do sujeito com aquele que simbolicamente encarna vida em comunidade, a proibição do incesto diz respeito a sua relação com a frátria, à relação com seus iguais. Trata-se de uma proibição que não carrega a marca do onipotente, mas sim um reconhecimento da importância da manutenção da reunião da frátria. Consideramos, assim, uma distinção entre o tabu do colocado pelo pai e o tabu postulado pela frátria. Retomando nossas preocupações específicas a respeito do conceito de instituição, pensamos que esta diferença de relação com os tabus oferece alguma luz para a discussão da relação dos sujeitos com as instituições sociais e com as organizações. A principal dificuldade encontrada na diferença entre instituições e organizações é quando nos aproximamos no campo das regras de conduta. Ambas apresentam suas regras, suas forças, que se por vezes se complementam, em outras atuam em sentido contrário. Mas como saber se uma norma é coerente com um sentido institucional da organização, ou se ela é fruto da necessidade de auto-preservação da organização? Há diferença, para o sujeito do inconsciente, entre estas duas normas? Podemos com esse estudo sobre a origem das coletividades e sobre os tabus dizer que sim. As normas vinculadas as instituições sociais, pelo que elas contém de representações de um imaginário social, pelo que elas remetem a uma moral internalizada no sujeito, apesar de referente a comunidade, assimilam-se muito mais ao que vemos encarnados no caso da proibição de assassinato do animal totêmico, tabu que tem por referência a culpa pela participação no assassinato do pai. As normas postuladas pelas organizações, que muitas vezes tem por fundamento apenas sua própria perpetuação, também encontra eco no psiquismo do sujeito uma vez que tem a mesma base de funcionamento do tabu do incesto: um reconhecimento e um investimento na manutenção dos laços que ligam a frátria. Esse retrato dos tabus oferece uma base psíquica para a diferenciação entre instituição e organização, mas ainda deixa em suspenso quais 
seriam suas bases metapsicológicas. Passemos agora para o funcionamento psíquico das massas.

\subsubsection{O PSIQUISMO NAS MASSAS: HERANÇAS}

Em Psicologia de massas e análise do eu, Freud nos apresenta suas considerações a respeito do funcionamento dos sujeitos no social. Pelas relações dos componentes da massa entre si e pela relação com a figura do líder (que poderia ser representada por uma pessoa ou por um ideal), constrói suas hipóteses. Trata-se do desdobramento de suas hipóteses lançadas em Totem e Tabu.

Consideremos a distinção, feita por Freud, entre as massas artificiais e as massas naturais. As massas artificiais se diferenciariam por exigirem uma força externa (regras e normas) para manter os indivíduos reunidos e, desta maneira, se aproximam de nosso conceito de organização.

\footnotetext{
Uma Igreja e um exército são grupos artificiais, isto é, certa força externa é empregada para impedi-los de desagregar-se e para evitar alterações em sua estrutura. Via de regra, a pessoa não é consultada ou não tem escolha sobre se deseja ou não ingressar em tal grupo; qualquer tentativa de abandoná-lo se defronta geralmente com a perseguição ou severas punições, ou possui condições inteiramente definidas a ela ligadas. Acha-se inteiramente fora de nosso interesse atual indagar a razão por que essas associações precisam de tais salvaguardas especiais. [FREUD, 1921/1976, p. 119]
}

Figueiredo (1998-1999) sugere que as compulsões externas necessárias para a manutenção das massas artificiais fazem-se necessárias para reduzir os riscos dos efeitos desagregadores que as pulsões de vida, que ligam os indivíduos uns aos outros (instintos de natureza libidinal), também podem despertar. Teriam elas um duplo objetivo: impedir a formação de núcleos eróticos dentro da massa (o que poderia separar os membros envolvidos nesse núcleo dos demais membros da massa) e coibir a deserção libidinal que poderia ser 
atraída pelo "lado de fora” do grupo. Considerando o índice libidinal que atravessa toda relação, mesmo que entre membros da massa esta possa ser sublimada, a organização convive sempre com a possibilidade de que essas relações voltem a buscar seu objetivo primário, o que não é de interesse do conjunto, para sua própria perpetuação; para que isso não ocorra, são necessários mecanismos por parte do conjunto (as regras e padrões de conduta) que operem na tentativa de reduzir estas tensões sexuais, por meio da homogeneização de seus membros. Ora, o que essa coerção, senão uma generalização do tabu do incesto, só que circunscrito a uma organização específica ao invés de um totem. Essa rígida coerção interna, por sua vez, acaba por despertar um grande interesse pelo que não faz parte do grupo; nesse "lado de fora” acaba sendo projetado tudo o que não pode ser vivido no grupo: seus sentimentos hostis (fruto das inibições impostas ao seu desejo) e também a possibilidade de satisfação total do desejo. As compulsões externas (regras) operam também contra essa atração. As regras organizacionais, então, responderiam a duas necessidades: 1) necessidade de inibir as metas sexuais primárias para que essa energia sexual possa ser usada para a união do grupo; 2) necessidade de controlar essa energia de maneira que não gere a desagregação do grupo, seja pelo excesso de erotismo entre os componentes do grupo, seja por um aumento da agressividade - fruto das frustrações das metas sexuais -, seja pela deserção de seus membros.

Desse funcionamento da relação entre os sujeitos na organização gostaríamos de ressaltar uma implicação especial para a situação analítica. Refere-se à inibição dos impulsos eróticos e dos impulsos hostis no contexto organizacional. Esse movimento é o oposto do que é provocado pelo processo analítico. Esse paradoxo não pode ser resolvido pela eliminação de um dos fatores, mesmo quando o fator institucional é ignorado. Ele passa a exigir dos sujeitos, neste caso em especial, do analisando, que se defronte com um conflito pulsional muito mais intenso e paradoxal - algo que pode gerar uma transferência ainda mais intensa com a 
instituição enquanto totalidade. Temos um quadro em que os afetos, incitados e interditados, encontram dificuldade em ser comunicados, encontrando vazão apenas na fantasia e na transferência.

Para prosseguirmos em nossa questão de verificar o estatuto psíquico de instituições e organizações, destacaremos dois outros aspectos abordados em Psicologia das massas...: o processo de identificação e o de idealização.

Além dos laços emocionais ambivalentes que ligam os sujeitos do conjunto, outro mecanismo que opera para a sua constituição é o das identificações. A incorporação do chefe da horda na refeição fraterna após o parricídio, e sua retomada ritual nas comunidades totêmicas, já apontava para a importância da identificação para a constituição do vínculo social. Agora, no entanto, Freud realiza um exercício mais rigoroso sobre o funcionamento deste mecanismo:

\begin{abstract}
A identificação, na verdade, é ambivalente desde o início; pode tornar-se expressão de ternura com tanta facilidade quanto um desejo do afastamento de alguém. Comporta-se como um derivado da primeira fase da organização da libido, da fase oral, em que o objeto que prezamos e pelo qual ansiamos é assimilado pela ingestão, sendo dessa maneira aniquilado como tal. [...] O primeiro tipo de laço [identificação], portanto, já é possível antes que qualquer escolha sexual de objeto tenha sido feita. É muito mais difícil fornecer a representação metapsicológica clara da distinção. Podemos apenas ver que a identificação esforça-se por moldar o próprio ego de uma pessoa segundo o aspecto daquele que foi tomado como modelo. [FREUD, 1921/1976, p. 133-4]
\end{abstract}

Notamos que a identificação, derivada da fase oral, refere-se a uma ingestão do objeto.

Desta maneira temos que a identificação com o pai pela comunidade de irmãos, tal qual o assassinato, também foi ato. Porém este aniquilamento do objeto a que se refere Freud provoca conseqüências no sujeito que se identifica. O objeto não mais existe enquanto tal, mas agora sujeito e objeto são um, e o ego do sujeito e moldado segundo esta fusão. Freud (1921/1976) descreve três possibilidades de identificação. Vejamos os dois primeiros:

A identificação pode provir do complexo de Édipo; nesse caso, significa um desejo hostil, por parte da menina, de tomar o lugar da mãe, e o sintoma expressa seu amor objetal pelo pai, ocasionando realização, sob a influência do sentimento de culpa, de seu desejo de assumir o lugar da mãe: 'Você queria ser 
sua mãe e agora você a é - pelo menos, no que concerne a seus sofrimentos'. Esse é o mecanismo completo da estrutura de um sintoma histérico. Ou, por outro lado, o sintoma pode ser o mesmo que o da pessoa que é amada [...]. Nesse caso, só podemos descrever o estado de coisas dizendo que a identificação apareceu no lugar da escolha de objeto e que a escolha de objeto regrediu para a identificação. [...]. É de notar que, nessas identificações, o ego às vezes copia a pessoa que não é amada e, outras, a que é. Deve também causar-nos estranheza que em ambos os casos a identificação seja parcial e extremamente limitada, tomando emprestado apenas um traço isolado da pessoa que é objeto dela.

Esses dois primeiros processos de identificação remetem a uma identificação frente ao objeto de desejo. Tratam-se de identificações que apontam para a figura do líder, quando este se encontra personificado. Estas identificações remontam a uma nostalgia vivida pelos sujeitos da situação psíquica da horda, onde era possível se conceber o lugar do onipotente. Dentro desta fantasia, ocupar seu lugar ou ser seu favorito são expressões de um mesmo desejo: a possibilidade de reviver um ideal de plenitude e satisfação, sem restrições ao desejo. Vejamos agora o que nos mostra a terceira fonte de identificação:

Suponha-se, por exemplo, que uma das moças de um internato receba de alguém de quem está secretamente enamorada uma carta que lhe desperta ciúmes e que a ela reaja por uma crise de histeria. Então, algumas de suas amigas que são conhecedoras do assunto pegarão a crise, por assim dizer, através de uma infecção mental. O mecanismo é o da identificação baseada na possibilidade ou desejo de colocar-se na mesma situação. As outras moças também gostariam de ter um caso amoroso secreto e, sob a influência do sentimento de culpa, aceitam também o sofrimento envolvido nele. [...] A identificação por meio do sintoma tornou-se assim o sinal de um ponto de coincidência entre os dois egos, sinal que tem de ser mantido reprimido [FREUD, 1921/1976, p.135-6, grifo nosso].

Isento de qualquer relação objetal com a pessoa copiada, na identificação por meio do sintoma a libido não está presente na relação, mas é direcionada a um mesmo alvo. Freud aponta esse tipo de identificação como aquele que se encontra entre os membros de um conjunto, pois a libido, tal como no exemplo das moças, estaria direcionado para a figura do líder e promoveria uma identificação entre os demais membros. Este seria, então, o mesmo laço que ligou originalmente os membros da frátria, laço que sustenta as organizações.

Quanto mais importante essa qualidade comum é, mais bem-sucedida pode tornar-se essa identificação parcial, podendo representar assim o início de um novo laço. [...] Já começamos a adivinhar que o laço mútuo existente entre os 
membros de um grupo é da natureza de uma identificação desse tipo, baseada numa importante qualidade emocional comum, e podemos suspeitar que essa qualidade comum resida na natureza do laço com o líder.

O laço comum com o líder experimentado pela massa remonta ao sangue único partilhado pelo grupo de irmãos após o parricídio. Entretanto a situação nas massas não é a mesma. O tempo fizera com que os motivos do assassinato ficassem distantes e quase esquecidos. O ódio ao pai que deu lugar primeiro a culpa, depois ao pacto ao com o totem, transformara-se em religiões em que o pai retornara como Deus. O pai que deixara de ser real pelo assassinato, como objeto simbólico passa a se tornar ideal. O laço com o líder que está na base da identificação das massas é um laço comum entre os membros do conjunto e um mesmo ideal.

Estamos [...] em perfeita posição de fornecer a fórmula para a constituição libidinal dos grupos, ou, pelo menos, de grupos [...] que têm um líder e não puderam, mediante uma 'organização' demasiada, adquirir secundariamente as características de um indivíduo. Um grupo primário desse tipo é um certo número de indivíduos que colocaram um só e mesmo objeto no lugar de seu ideal do ego e, conseqüentemente, se identificaram uns com os outros em seu ego. (p.147)

Para compreendermos melhor esta fórmula, se fazem necessários alguns esclarecimentos a respeito do ideal de ego. Busquemos essas informações num artigo anterior de Freud (1914, p. 111):

O narcisismo do indivíduo surge deslocado em direção a esse novo ego ideal, o qual como o ego infantil, se acha possuído de toda perfeição de valor. Como acontece sempre que a libido está envolvida, mais uma vez aqui o homem se mostra incapaz de abrir mão de uma satisfação de que outrora desfrutou. Ele não está disposto a renunciar à perfeição narcisista de sua infância; e quando, ao crescer, se vê perturbado pelas admoestações de terceiros e pelo despertar de seu próprio julgamento crítico, de modo a não mais poder reter aquela perfeição, procura recuperá-la sob a nova forma de um ego ideal. O que ele projeta diante de si como sendo seu ideal é o substituto do narcisismo perdido de sua infância na qual ele era o seu próprio ideal. 
Em Sobre o narcisismo: uma introdução, Freud postula que o ideal de ego é um substituto do ego ideal infantil. Por conta de sua origem, vemos que o ideal de ego é uma instância que herda as características narcísicas do sujeito. Este narcisismo, porém, opera como instância crítica ao ego do sujeito, por no interior de seu próprio psiquismo diferenciarse do eu, lhe mostrando constantemente a falta de sua potência. Trata-se, como podemos perceber, da instância psíquica que cumpre a função do pai internalizado - lugar de onipotência que dentro do sujeito lhe mostra o quão distante ele está desse poder e o castiga por isso - e que deixará brechas para a aderência do sujeito a massa, e em especial à figura do líder.

Até aqui, apesar de termos descrito os mecanismos que nos permitirão distinguir entre os processos organizacionais dos institucionais, ainda encontramos dificuldades em discriminar o processo de identificação, que vinculam os membros da massa entre si, e este processo de idealização, que faz com que a figura de um líder possa ser colocada no lugar do ideal de ego de cada um dos sujeitos da massa. Recorreremos então a interpretação de Enriquez (1983c/1991, p.68) destes processos.

\begin{abstract}
Esboça-se aí a distinção entre identificação e substituição. Existe uma (ou muitas) identificação quando o objeto (desaparecido ou se mantendo) se torna parte integrante ego; por outro lado, trata-se de uma substituição quando o objeto é posto no lugar do que constitui o ideal do ego. Assim, através da introjeção, a identificação com os pais permite ao sujeito assimilar propriedades e atributos dos mesmos e se transformar conforme o modelo que eles propõem, independentemente de suas presenças ou ausências na realidade. O ego se torna, então, o produto do conjunto de identificações passadas. A situação de substituição, ao contrário, é percebida quando aquilo que era para nós um ideal se localiza num objeto presente que vem, no interior de nós mesmos, representar completamente e sem crítica esse ideal.
\end{abstract}

Para o processo que faz o líder ocupar o lugar de ideal do ego, Enriquez cunha o termo substituição, que também adotaremos. Consideramos que esta citação é bastante clara quanto aos conceitos e partiremos dela para começarmos a delimitar nossa concepção instituição e de organização. A relação do sujeito com as instituições sociais, na medida em que estas se 
referem à organização da estrutura social, aos sentidos de suas manifestações e a normas e padrões de conduta esperados, é uma relação que se constitui exclusivamente pelas identificações, em especial as dos dois primeiro tipos descritos por Freud. Ego e ideal de ego são afetados e se modificam na relação do sujeito com as instituições sociais; desdobramento da identificação primitiva com o pai morto, a assimilação das normas institucionais enfrenta a mesma ambivalência de sentimentos e mesmo que possa ser deslocada para objetos reais, é sempre uma relação com um objeto mítico, por isso poderoso. As instituições, nos mesmos moldes dos animais totêmicos, condensam em si a figura do pai, e o poder de toda uma comunidade. Trata-se de uma relação de constantes identificações que modelam tanto seu ego quanto seus ideais e fazem sua identidade compor-se de todas as instituições a qual ele pertence.

\begin{abstract}
Cada indivíduo é uma parte componente de numerosos grupos, acha-se ligado por vínculos de identificação em muitos sentidos e construiu seu ideal do ego segundo os modelos mais variados. Cada indivíduo, portanto, partilha de numerosas mentes grupais - as de sua raça, classe, credo, nacionalidade etc. podendo também elevar-se sobre elas, na medida em que possui um fragmento de independência e originalidade. [FREUD, 1921/1976, p.163]
\end{abstract}

As relações do sujeito com as organizações, por sua vez são mais complexas: podem ser de substituição, de identificação (dos três tipos), ou ainda relações de vínculo libidinal ou hostil, uma vez que a organização é sempre encarnada por um conjunto de pessoas. O vínculo que liga o sujeito às organizações é sempre um vínculo entre sujeitos e portanto contempla toda a complexidade e diversidade que uma relação entre sujeitos pode contemplar. Porém apesar da diversidade na qualidade de vinculações existentes em uma organização, podemos compreender que todas elas apontam para um mesmo sentido: o impedimento da satisfação pulsional direta e a manutenção do agrupamento. Enriquez (1983b/1991, p.36) trata o assunto da seguinte forma: 
Para se constituir, uma sociedade deve impedir a realização não-mediatizada da satisfação da pulsão sexual. A expressão pulsional direta é incompatível com a criação do socius; este só se constrói em relação a um desejo, e o desejo só se faz ouvir na medida em que responde a uma lei de organização. Contudo, somos obrigados a escutar igualmente o rumor obsedante da pulsão sempre presente, buscando a satisfação, minando o sistema social criado que, para se proteger, deve erigir continuamente proibições extremamente complexas. [ENRIQUEZ,]

Se a relação institucional é herdeira de relação do sujeito com o pai morto, as organizações são herdeiras da necessidade do sujeito de pertencimento a frátria. Parafraseando Freud, pelo pertencimento a organização o sujeito tem a coragem e é bem sucedido naquilo que lhe seria impossível fazer individualmente. Enquanto as instituições configuram sentidos, de maneira sempre conflituosa, para a existência social do sujeito, as organizações fazem uso de diversas maneiras para repetirem sempre o mesmo sentido: a manutenção do conjunto. Para isso a única via aceita pela organização de satisfação sexual é a via sublimada, que responde às leis da organização e evita a reedição dos conflitos primevos. Entretanto, temos que a organização é constituída de sujeitos, que por sua vez necessitam também da satisfação direta de suas pulsões sexuais para continuarem funcionando de maneira saudável. A organização funciona, desta maneira, sempre sob a tensão de leis que devem falhar em algum momento. A sublimação e a satisfação pulsional direta são os processos que sustentam esse paradoxo que faz com que as organizações dependam tanto das leis quanto da quebra dessas mesmas leis para sobreviver.

Antes de encerrarmos este tópico sobre o conceito de instituição, toquemos em um último ponto: as massas sem líder. Freud (1921/1976) afirma que a função de líder pode ser ocupada por uma idéia ou desejo comum da massa. Porém é em Enriquez (1983c/1991, p. 75) que encontramos um desdobramento interessante desta possibilidade:

Ao notar que um desejo pode preencher "esse mesmo papel de substituição”, ele [Freud] nos mostra, sem dizê-lo explicitamente, que uma substituição pode se realizar por projeção. Efetivamente, os indivíduos projetam seus desejos fora deles mesmos e os reencontram em sua totalidade no mundo exterior. Assim, ao se reconhecerem forçosamente nele, têm ainda menos dificuldade para aceitá-lo, interiorizá-lo e submeterem-se a ele. [...]. Este processo é particularmente importante, pois revela que muitos grupos podem existir sem chefe anterior 
(chefe real), com a condição de que possam inventar um objeto transcendente que guie suas vidas. [...] Vê-se esboçar aí uma nova concepção de grupo, onde o primeiro motor não seria uma pessoa, mas a complementaridade dos desejos das pessoas que criam instituições que lhes parecem naturais, para alcançar seus fins de onipotência.

Vemos aqui a possibilidade do nascimento de instituições. Pelo mesmo mecanismo que oprime o sujeito na realização de seus desejos, encontramos também uma possibilidade de realização, que por sua vez opera uma mudança no quadro social. Infelizmente não está dentro do alcance do presente estudo desenvolver estes desdobramentos, mas ressaltemos a relevância dessa projeção de ideais dos quais uma instituição poderia ser resultado.

Retornando ao objeto e nosso estudo, quanto às identificações e substituições presentes nas organizações e às identificações referentes às relações institucionais, o analista deve estar muito mais atento à sua atuação do que a manifestação do paciente. O analista que se vincula a uma organização, regida por determinadas instituições, adere a certos ideais que poderão ser também os ideais do paciente que escolhe a mesma organização para ser atendido; se esse registro identificatório não puder ser detectado, o próprio processo analítico corre o risco de se tornar sintoma, na medida em que pode se tornar o ponto de coincidência frente aos ideais postulados pela instituição para analista e analisando.

Feitos nossos primeiros esclarecimentos sobre a instituição que iremos abordar, caminharemos agora para a relação entre sujeito e instituição na constituição subjetiva. Nosso objetivo agora será o de estabelecer as ligações entre o institucional e a constituição da realidade psíquica do sujeito, que está na base da transferência, e como essas ligações continuam a ser atualizadas nas relações do sujeito com as instituições.

\subsection{A SOCIALIZAÇÃO DA PSIQUE}

A primeira razão que encontramos para explorar a relação entre sujeito e instituição, ainda no capítulo anterior, foi compreender de que maneira a constituição da realidade 
psíquica do sujeito se encontra modelada por esta ligação e estrutura a própria transferência. Comecemos por analisar alguns aspectos desta realidade psíquica.

É nessa instauração da clivagem entre o consciente e o inconsciente, e por via indireta também da clivagem entre o psíquico e o não-psíquico, que intervém o recalque originário, que concebemos como a constituição de um inconsciente radicalmente clivado, ou seja, de uma "realidade psíquica" no sentido estrito do termo. Não um domínio da realidade que seria psíquico ("psíquico” sendo um adjetivo que qualifica tal realidade apenas enquanto psicológica), mas um psíquico que seria realidade, que seria coisa, inconsciente (LAPLANCHE, 1993, p.197).

Nosso interesse sobre a realidade psíquica é seu estatuto de realidade, que a citação acima descreve. Buscamos compreender como a instituição, ou o institucional, se relaciona com essa realidade e qual seu estatuto para o inconsciente. A visão de Laplanche (1993, p.81) é de que a realidade psíquica, núcleo duro da realidade subjetivo-psicológica, constitui-se como expressão última e mais verdadeira dos desejos inconscientes. Enquanto Freud atribui uma estrutura transindividual para esse núcleo duro (mito de origem, complexo de castração e complexo de Édipo), Laplanche questiona o quanto isso é passível de uma estruturação universal. Para explorar a questão sobre a singularidade da realidade psíquica e sua estruturação transindividual, acompanhemos algumas idéias de Castoriadis (1975/1982) e Aulagnier (1975/1979).

Recuperemos a ontologia do sujeito, voltando a um momento anterior ao recalcamento primário, o momento do originário, da mônada psíquica em que representação, intenção e afeto são idênticos entre si e, mais que isso, são o mesmo. É nesse estado originário que se encontra a origem da imaginação radical (CASTORIADIS, 1975/1982), em que a onipotência é real, não há falta, mas sim totalidade. Essa totalidade, com sua lógica própria e particular, que encontramos presente, ainda e sempre, no funcionamento do inconsciente e em especial nos sonhos, nas fantasias e também na transferência, é regido integralmente pelo princípio do prazer. 
Esta representação está automática e integralmente sob o reinado do princípio do prazer. Ela é o antes do desejo, posto que um “objeto" que não existe não poderia faltar, e o que existe é o que deve existir: ela fornece para sempre ao desejo seu objetivo impossível, o de um estado em que a presença do "objeto" e a satisfação são por construção asseguradas, na medida em que "sujeito" e "objeto" do desejo se encontram sem excesso nem falta, coincidem automaticamente. Toda a energia psíquica do sujeito só pode investir nesta etapa este "si mesmo tudo" que é o sujeito, ela só pode ser libido narcísica primária absoluta, ou melhor, libido "autística" - isto é, excluindo o elemento refletido implicado no narcisismo, fosse ele "primário": não "se" tomar por "objeto", partir de si para aí voltar, mas permanecer imediatamente perto de si ou em si. Ela é, finalmente, em seu caráter sem-sentido, a matriz e o protótipo daquilo que será sempre o sentido para o sujeito: o estar-junto indestrutível, visando-se a si mesmo e fundado sobre si mesmo, fonte ilimitada de prazer a que nada falta e que nada deixa a desejar (CASTORIADIS, 1975/1982, p.336).

É esse estado originário total, de libido autística, que por ocasião de seu rompimento vem gerar o desejo irrealizável de retornar a este estado. O desejo nasce como desejo de um estado e não de um objeto:

Do momento em que nos afastamos das formações secundárias, a idéia de objeto do desejo, em psicanálise, aparece claramente como um resíduo realista. O que o desejo visa não é um "objeto", mas este "estado", esta "cena” que, quando a podemos captar (e só podemos fazê-lo, por definição, nas formas derivadas e secundárias) implica não somente um "sujeito" e "objetos", mas uma certa relação entre eles (obviamente sempre especificada, de uma maneira ou de outra, nas formas que nos são acessíveis e que trazem as marcas profundas de toda a história ulterior do sujeito) - e é nessa relação que se encontra o sentido da fantasia para o sujeito (sendo os “objetos" sempre contingentes e fungíveis) [...]. O único desejo irrealizável (e por isso mesmo indestrutível) para a psiquê é o que visa, não aquilo que jamais poderia apresentar-se no real, mas aquilo que jamais poderia ser dado como tal, na representação - isto é, na realidade psíquica. [...] A psiquê é seu próprio objeto perdido (CASTORIADIS, 1975/1982, p.339).

Procuramos delimitar com essas passagens aquilo que na realidade psíquica é singular e escapa à influência transindividual. É o registro desse estado monádico da psique, que é o próprio fluxo de representações inconscientes, que permite o que Castoriadis denominou de “imaginação radical”, resíduo do estado onipotente que, enquanto tal e regendo o funcionamento do inconsciente, permite ao sujeito um desejo capaz de operar desvios aos esquemas que lhe são atribuídos por seu meio. Outro ponto importante do estado originário é seu caráter de cena total, e não de relação objetal; quando exploramos a transferência, 
apontamos que esta é despertada muito mais pela configuração de uma situação, do que pela associação a uma figura, e que a instituição ajusta-se muito mais a uma cena do que a um objeto. Consideramos que essa característica da transferência se apóia nessa origem do desejo, que remete a uma cena total.

\begin{abstract}
A mirada inconsciente é a situação global montada pela fantasia sob a modalidade fundamental da indistinção do sujeito e do não-sujeito. Vem a significar o mesmo dizer que toda fantasia incluído uma multiplicidade de elementos representativos “distintos” é por definição secundária: a presença de tais elementos sob a forma da "distinção" é a marca irrecusável de uma elaboração - mas traz a marca do estado originário da psiquê na medida em que esta visa a coincidir aqui com a cena total, porque seu estado originário, a “primeira” representação, é “cena total” (CASTORIADIS, 1975/1982, p.328).
\end{abstract}

Para trabalharmos, agora, com o aspecto transindividual da realidade psíquica, busquemos o conceito, em Aulagnier (1975/1979, p.106), de porta-voz:

Este termo define a função atribuída ao discurso da mãe, na estruturação da psique: porta-voz no sentido literal do termo, pois é a esta voz que o infans deve, desde seu nascimento, o fato de ter sido incluído num discurso que, sucessivamente, comenta, prediz, acalenta o conjunto de suas manifestações, mas porta-voz, também no sentido de delegado, de representante de uma ordem exterior cujo discurso enuncia ao infans suas leis e exigências.

Os dois sentidos possíveis para a função porta-voz dizem respeito a seu caráter intermediário entre o infans e o discurso do meio social. A função cumprida pela mãe garante tanto a entrada do sujeito num conjunto que o precede quanto permite a ele compreender o código deste grupo. Deteremo-nos nessa segunda função, que nos auxiliará a compreender a constituição do sujeito pela dimensão que estamos denominando de institucional.

A possibilidade de o sujeito ter acesso ao mundo passa necessariamente pela capacidade da mãe se oferecer como uma prótese ao seu psiquismo. É a psique materna que dota os objetos de um índice libidinal e permite que possam ser assimilados pelo infans. Entretanto, essa passagem dos objetos do mundo pela psique materna é marcada também pelo crivo de seu recalcamento. O psiquismo infantil, ainda dotado apenas dos funcionamentos 
primário e originário, metaboliza esse material seguindo unicamente o princípio do prazer. Temos o seguinte quadro:

O resultado é que a representação de um objeto modelado pelo trabalho de repressão será metabolizado numa representação que ainda não sofreu o efeito da repressão. Podemos, portanto, dizer que a psique se apropria de um objeto marcado pelo princípio da realidade, metabolizando-o em um objeto modelado apenas pelo princípio do prazer. Nesta operação aparecem: uma diferença (por exemplo, a que separa a satisfação alucinatória da satisfação real) e um resíduo (que induz a psique a reconhecer a presença de um "outro-espaço-mesmoespaço”) [...]. O efeito de prótese se manifesta, no espaço psíquico do infans, pela irrupção de um material marcado pelo princípio da realidade e, portanto, pelo discurso, o qual impõe, desde cedo, àquele que não tem ainda o poder de apropriar-se deste princípio, a intuição de sua existência. A psique do infans remodelará este material, sem poder, entretanto, impedir que se introduzam em seu próprio espaço, resíduos que escapam ao seu domínio e constituem os precursores necessários à atividade do secundário [AULAGNIER, 1975/1979, p.108-9].

Localizamos, nessa passagem, a instauração de um primeiro resíduo, alheio à totalidade onipotente do sujeito. Podemos dizer que essa situação coincide com sua entrada no mundo, pois a própria apreensão de um mundo depende que este tenha passado pelo crivo representativo da mãe. Para nossos fins, destacamos dois elementos desse processo: o primeiro diz respeito à função co-recalcadora da mãe e do discurso social em relação ao material metabolizado pelo sujeito; o segundo se refere ao fato do princípio de realidade, inerente aos objetos metabolizados pelo sujeito, ser precursor do que depois culminará no processo secundário e na apropriação do discurso social.

Ao avaliarmos a transferência, percebemos que esta remetia às fantasias relacionadas aos complexos parentais do sujeito e à configuração de suas relações objetais. Pela função porta-voz, encontramos que a marca de uma dimensão institucional é anterior, ou pelo menos é condição, de qualquer relação objetal. Ao observarmos que os objetos metabolizados pelo originário e pelo primário encontram-se, desde então, marcados pelo processo de recalcamento da mãe, e considerando que esta é porta-voz de um discurso que também lhe foi transmitido um dia, percebemos que parte do recalcamento, que está na origem da 
constituição do sujeito, já se dá numa esfera institucional, ou seja, numa esfera de sentidos que lhe escapam em sua singularidade e de que ao mesmo tempo ele irá se apropriar e dar sentido. Esse material, recalcado numa esfera externa, é restituído pelo princípio do prazer, em seus processos originário e primário, para, posteriormente, voltar a ser recalcado, desta vez pelo próprio sujeito. O que pretendemos destacar, nessa formulação da função porta-voz cumprida pela mãe, é que tanto o sujeito possui, em sua realidade psíquica, uma tendência ao retorno à cena total singular, quanto possui também um resíduo que foge à sua onipotência totalizadora - resíduo que é precursor, por ter a mesma natureza, da possibilidade de assimilação das instituições.

A existência deste resíduo, trabalhada ainda no registro do princípio do prazer, não é suficiente, ainda, para o rompimento do bebê com sua fantasia monádica. O próximo passo para que o processo de socialização ocorra é a fundação de um espaço externo à psique:

Não há dúvida de que, inicialmente, a criança não distingue entre o seio e o seu próprio corpo; quando o seio tem de ser separado do corpo e deslocado para o "exterior", porque a criança tão freqüentemente o encontra ausente, ele carrega consigo, como um "objeto", uma parte das catexias libidinais narcísicas originais. Este primeiro objeto é depois completado na pessoa da mãe da criança, que não apenas a alimenta, mas também cuida dela e, assim, lhe desperta um certo número de outras sensações físicas, agradáveis e desagradáveis. Através dos cuidados com o corpo da criança, ela se torna seu primeiro sedutor. Nessas duas relações reside a raiz da importância única, sem paralelo, de uma mãe, estabelecida inalteravelmente para toda a vida como o primeiro e mais forte objeto amoroso e como protótipo de todas as relações amorosas posteriores - para ambos os sexos [FREUD, 1940/1996, p.202].

A relação com a mãe institui a primeira possibilidade de um outro, externo ao espaço psíquico da criança. Esse espaço externo, co-fundado pela possibilidade de um outro, ainda carrega consigo muito de seus investimentos libidinais narcísicos. Porém, essa “externalidade” instituída surge também como possibilidade de lidar com as sensações desagradáveis:

Um “fora” é criado para que a psiquê possa para aí expulsar o que não quer, aquilo para o que não há lugar nela, o não-sentido ou sentido negativo, o seio 
como ausente, o seio mau. É evidente que esta constituição de um objeto embrionário só é possível na e pela constituição simultânea de um "espaço exterior". [...] Aquilo que depois será "mundo" e “objeto" é literalmente projeção, que é em sua origem expulsão do desprazer [CASTORIADIS, 1975/1982, p.346].

A partir do momento em que se institui um fora, o seio gratificante não pode mais ser idêntico ao ego e o "eu sou o seio” ganha seu segundo sentido de introjeção e incorporação, uma relação de predicação possessiva ou atributiva a si. Essa externalização, que permite o surgimento de um outro, no entanto, não é suficiente para que o sujeito abandone o registro da onipotência:

O objeto [...] só é constituído como real no momento em que está verdadeiramente "perdido", porque definitivamente situado em poder de um outro. Sem dúvida, também, o outro só é estabelecido como tal a partir do momento em que pode ser estabelecido como aquele que dispõe do objeto. Ele [o bebê] só pode constituir um outro, projetando nele seu próprio esquema imaginário de onipotência [CASTORIADIS, 1975/1982, p.347-8].

A onipotência projetada no outro não pode ser destituída pela realidade, na medida em que ela própria é condicionada pelo poder de significação do outro, nem pela atribuição do outro a um novo outro onipotente (por exemplo, a mãe investindo o poder no pai). Somente limita-se a onipotência do infans se o outro mostra que ninguém detém esse poder, ou seja, pela instituição da sociedade, oriunda de um imaginário social. São os indivíduos sociais que retiram o sujeito de sua loucura monádica:

Porque, é claro, o pai não é pai se ele mesmo não se liga a uma sociedade e a sua instituição, se não é significado para a criança que ele é um pai entre outros pais, que o é na medida em que deseja ocupar um lugar que não estava em seu poder criar, e que assim ele figura e presentifica para a criança o que explicitamente ultrapassa a ele próprio em grau infinito - uma coletividade anônima e indefinida de indivíduos que coexistem na e pela instituição e se continuam num sentido e no outro do tempo [CASTORIADIS, 1975/1982, p.352].

Se ao abordamos a função porta-voz já se colocava inegavelmente a dimensão institucional como significativa para a constituição do sujeito, ainda que apenas configurando- 
se como um resíduo para a psique, o complexo de Édipo coloca em tema a importância dessa dimensão para a socialização da psique. A situação edípica não é mais manipulável como era a relação com a mãe. O objeto de desejo onipotente - a mãe - se destitui de sua onipotência e se apresenta como sujeito de um desejo (o objeto de desejo do bebê passa a ter outro objeto de desejo também fora do bebê). Ali onde é excluído, o sujeito encontra a sua origem, uma vez que pode reconhecer os outros seres humanos como sujeitos de desejos autônomos, que podem ligar-se uns aos outros independentemente dele. O complexo de Édipo fala do reconhecimento do desejo de um outro, reconhecimento de um desejo a que não se tem acesso e que só pode ocorrer via instituição social, em que o reconhecimento de que todos podem ser detentores de um desejo, do qual não se pode dispor, faz com que ninguém possa dispor de seu desejo de maneira onipotente. A instituição social, ao mesmo tempo em que rompe com a estrutura monádica da psique, permite ao sujeito que seu desejo se abra às múltiplas significações da cultura - para além do proto-sentido anterior, que continua a reinar no inconsciente - e estabelece para o sujeito seus modelos e marco identificadores. Para o indivíduo se torna possível e necessária a sublimação:

\footnotetext{
A sublimação é o processo mediante o qual a psiquê é forçada substituir seus "objetos próprios" ou "privados" de investimento [...] por objetos que são e valem na e pela instituição social. E fazer para ela mesma, “causas”, "meios” ou suportes de prazer [CASTORIADIS, 1975/1982, p.356].
}

É a mudança do objeto, que, no inconsciente, faz coexistirem diversas representações distintas e idênticas, que faz com que as coisas e os indivíduos tomem o lugar dos “objetos” e os signos privados dêem lugar a uma linguagem pública. Na medida em que se pode, então, reconhecer os outros como sujeitos de um desejo autônomo, a dimensão intersubjetiva pode deixar de ser apenas psíquica para tornar-se social, tornar-se política, pode abandonar as fantasias para ganhar o espaço público que é o espaço das instituições. Temos, então, que a dimensão institucional, em seu aspecto psíquico, acompanha e interfere a maturação da psique 
do sujeito até que possa emergir em seu aspecto social e político. O que não significa que essa maturação seja definitiva, ou que seus aspectos mais primitivos sejam totalmente eliminados. Tal como a transferência nos faz lembrar, os modelos mais primitivos de funcionamento continuam em ação no inconsciente, e notamos que a dimensão institucional participa ativamente da constituição desses modelos, independentemente de estar presente no contexto da situação analítica.

\subsection{O SUJEITO E AS INSTITUIÇÕES: COMPREENDENDO O LACCO SOCIAL}

Analisemos agora o laço que une o sujeito constituído e o conjunto social. Esta relação passa, primeiramente, pela possibilidade da nomeação do mundo, possibilidade de um reconhecimento partilhado, de um discurso social. Só a partir da constituição deste pacto de mútua determinação que podemos começar a analisar a relação entre a esfera do conjunto e do sujeito.

Se estivessem apenas em uma relação narcísica com o sujeito, os objetos não seriam nunca percebidos senão de maneira instantânea. A nomeação constitui um pacto, pelo qual dois sujeitos, ao mesmo tempo, concordam em reconhecer o mesmo objeto. Se o sujeito humano não denominar, se os sujeitos não se entenderem sobre este reconhecimento, não haverá mundo algum, nem mesmo perceptivo, que se possa manter por mais de um instante [Debieux, 2001]

Partindo do princípio de que a análise do sujeito e do conjunto passa necessariamente por uma nomeação, por um discurso, podemos assim definir também o que entendemos por um registro sócio cultural - no qual se inserem as instituições -, que extrapolaria um conjunto específico de sujeitos. Para isso recorremos a uma definição de Aulagnier (1975/1979):

Por registro sócio-cultural compreendemos o conjunto de instituições, cujo funcionamento participa de um mesmo traço característico: ele é acompanhado por um discurso sobre a instituição, que afirma seu fundamento e sua necessidade. [...]. Representaremos metonimicamente o grupo social [...] como $o$ conjunto das vozes presentes. Este conjunto pode pronunciar um número indeterminado de enunciado: entre eles, ocupará um lugar particular a série que define a realidade do mundo, a razão de ser do grupo, a origem de seus modelos. [AULAGNIER, 1975/1979, p.146-7]. 
Estes enunciados, destacados pela autora, que tem como objeto o próprio grupo são nomeados como enunciados do fundamento ou fundamento dos enunciados. Esta série de enunciados pode ser, dependendo da cultura, mítico, científico ou sagrado. Independentemente disso, os enunciados do fundamento são sempre palavras de certeza, e quando perdem essa característica são imediatamente substituídos por uma nova série que possa cumprir esta função. Esses enunciados sempre falam também sobre a origem do próprio modelo, origem que implica em uma finalidade para a qual tende o próprio modelo. As características comuns a todo discurso fundador da cultura, seja ele científico, mítico ou sagrado, são:

- A voz originária é suposta por enunciar o eternamente verdadeiro. Graças a este postulado, constitui-se um setor de certeza absoluta no registro do discurso.

- Ela assegura ao Eu a existência de uma série de enunciados, presentes no texto sagrado, que são um certificado da identidade entre o Eu enunciante e o Eu que garante a verdade deste discurso.

- Ela permite ao Eu apropriar-se de um fragmento de discurso, cuja verdade é independente da confirmação ou da desconfirmação fornecida pelo outro, interlocutor singular. Quando o Eu repete o discurso sagrado, ele se outorga o direito de reivindicar a priori o reconhecimento de sua verdade pelo grupo e de excluir quem o contradiz, o qual recusa uma certeza partilhada pelo meio.

O sujeito, ao aderir ao campo social, se apropria de uma série de enunciados que sua voz repete: esta repetição lhe traz a certeza da existência de um discurso, no qual a verdade sobre o passado está garantida, tendo como corolário a crença na possível verdade das previsões sobre o futuro. [AULAGNIER, 1975/1979, p.146-7]

Quando o sujeito se apropria do discurso do meio, ou de outra maneira, se identifica com determinada instituição social, apropria-se também de seu estatuto de verdade. É este estatuto que o liberta da submissão à verdade de outrem, podendo questionar qualquer verdade individual em nome de uma certeza partilhada pelo meio. Além disso, essa repetição do discurso do meio, que lhe garante uma certeza em relação ao seu passado, tem como conseqüência a possibilidade de verdade nas previsões sobre o futuro. É esse registro de verdade presente no discurso do meio e internalizado pelo sujeito que o permite apreender o registro da história. 
O tempo futuro, no qual o sujeito sabe que não mais existirá, pode, desde então, ser por ele representado como continuação de si próprio e de sua obra, graças à ilusão que lhe faz crer que uma nova voz virá reatribuir vida à mesmice de seu próprio discurso, escapando, assim, ao veredicto do tempo.

Podemos agora discutir como se dá este laço que une sujeito e meio, que oferece a ambos a possibilidade de enfrentar o "veredicto do tempo". Vejamos o que Aulagnier nos diz sobre o contrato narcisista.

O contrato narcisista se estabelece graças ao pré-investimento do infans pelo meio, como voz futura que ocupará o lugar que lhe será designado, dotando-o antecipadamente e por projeção do papel de sujeito do grupo. A existência do meio pressupõe que a maioria de seus elementos veja nas exigências de seu funcionamento, o que permitiria o alcance do meio ideal, se estas exigências fossem integralmente respeitadas. A crença neste ideal será acompanhada da esperança na permanência e na perenidade do conjunto. Desde então o sujeito poderá, de forma relativa, estabelecer uma identidade entre possibilidade de perenidade do conjunto e desejo de perenidade do indivíduo [AULAGNIER, 1975/1979, p.150-1].

O contrato narcisista se caracteriza pelo interesse mútuo do conjunto e do sujeito de que o discurso social se perpetue. Para que o discurso do meio se mantenha vivo, o grupo préinveste seus herdeiros antes mesmo de seu nascimento. $\mathrm{O}$ investimento no sujeito tem o interesse narcísico de que esse sujeito possa repetir, depois de formado, o discurso do meio, com os mesmos recalques e os mesmos tabus exigidos para sua permanência. Por sua vez, o sujeito encontra nesta relação com seu meio a possibilidade de abandonar o funcionamento monádico e o suporte parental, ao mesmo tempo em que lhe é oferecida uma certeza compensatória sobre sua origem, localizada no mito de origem do próprio grupo. Apropriar-se do discurso do grupo como um discurso que também lhe pertence, garante ao sujeito acesso à dimensão histórica, essencial para a constituição de uma autonomia para o funcionamento de seu Eu, que, apoderado de uma origem, podem se lançar rumo a ideais futuros e se mover entre modelos identificatórios. O contrato narcisista aponta para um ideal e, com isto, também para o desejo de uma superação do tempo. Desta forma, é também um investimento narcísico que o sujeito transfere ao grupo, na medida em que este lhe garante a ilusão de que seu 
discurso será perenizado pelos herdeiros do grupo. Sobre essa ligação intrínseca entre sujeito e grupo, Kaës (1997) faz algumas considerações:

De certa maneira, não temos a inteira escolha de não sermos postos juntos no agrupamento, tanto quanto não temos escolha ter ou não um corpo: é assim que vimos ao mundo, pelo corpo e pelo grupo, e o mundo é corpo e é grupo [...]. O inelutável é que somos postos no mundo [...] por mais de um outro, por mais de um sexo, e que nossa pré-história nos faz, já bem antes do desligamento do nascimento, o membro de um casal, sujeito de um grupo, seguros por mais de um outro como servidores e herdeiros de seus "sonhos de desejos irrealizados" [...]. É nesse conjunto que o recebe, nomeia-o, que o sonhou, investiu-o, colocou e falou que o sujeito do grupo se torna sujeito falante e sujeito falado, não pelo único efeito da língua, mas pelo efeito do desejo daqueles que - como a mãe primeiro - fazem-se também porta-vozes do desejo, da proibição, das representações do conjunto [KAËS, 1997, p.275-6].

O sujeito é constituído por determinação do inconsciente no espaço intrapsíquico (sujeito a leis e propriedades orgânicas) e por determinação do conjunto que o precede. A determinação do conjunto a que se refere Kaës (1997) se manifestaria por uma malha psíquica intersubjetiva - na medida em que a possibilidade do sujeito, enquanto sujeito do grupo, se apóia no desejo e nos significantes do conjunto - em que cada aparelho psíquico (considerado também em sua condição de corpo) introjeta, incorpora, se identifica, transforma e transmite, como uma exigência de submetimento do e ao conjunto, promovendo preservação e continuação de si, enquanto sujeito singular, e do grupo. Nesse processo de se fazer representar e ser representado pelo conjunto, tais representações transitam pelo aparelho psíquico singular e podem integrá-lo ou não - trata-se da flexibilidade de significações conquistada pelo abandono do registro onipotente. Esse processo ocorre nos diversos conjuntos em que o sujeito se insere e transita no decorrer da vida, não apenas em seu conjunto primário, e cada um tem suas próprias exigências e recompensas para a constituição do sujeito, que caberá ao seu aparelho psíquico integrar. Tratar-se-á sempre da relação entre a integridade de sua imagem para os outros e sua auto-representação como suporte para todo sentido e significação. A sociedade institui o indivíduo e em troca lhe dá acesso à sua rede de 
significações. O indivíduo, em troca, perpetua essa rede. É por meio dele também que o conjunto pode reconstruir seus ideais e romper com modelos identificatórios que levem o grupo à extinção, uma vez que é pela possibilidade do sujeito se adequar ou não aos modelos sociais que lhe são oferecidos que esses mesmos modelos podem se modificar. A representação nesse momento volta de outra maneira a ser fonte direta de prazer - tal como eram as representações que alimentavam o funcionamento originário e primário -, porém agora mediada por algo do qual o sujeito singular não dispõe: o conjunto de sujeitos.

O que procuramos destacar, em relação ao contrato narcisista e à constituição do sujeito enquanto sujeito do grupo, é a maneira narcísica como o sujeito se insere e é recebido em sua relação com o discurso social. Esse processo, que está na origem da possibilidade de socialização, se realiza também na inserção do sujeito nos diversos grupos que ele vem a percorrer durante sua vida. Um conflito entre o grupo primário de pertencimento e os demais grupos de pertencimento social pode resultar em riscos para a constituição do sujeito. Sobre esses riscos Aulagnier (1975/1979, p.147) observa:

O conflito que pode existir entre o casal e o meio corre o risco de confirmar,
para a psique infantil, a identidade entre o que ocorre na cena exterior e sua
representação fantasmática de uma situação de rejeição, de exclusão, de
agressão, de onipotência. A realidade da opressão social sobre o casal, ou da
posição dominante exercida pelo casal, desempenhará um papel na maneira pela
qual a criança elaborará seus futuros enunciados identificatórios. Não é por mero
acaso que a estória familiar de boa parte dos psicóticos [caso extremo dessa
influência perturbadora do meio na constituição da subjetividade] repete
freqüentemente um mesmo drama social e econômico: esta realidade, que
quebra todo parêntese, tem um papel, no destino destas crianças, que a
sociedade, num segundo tempo, envia às diferentes instituições, para que elas
reparem os estragos do qual ela é responsável.

Apesar da universalidade do contrato narcisista, a quantidade de libido investida no grupo varia de sujeito para sujeito, de casal para casal, entre os elementos do casal e entre os meios. Neste último ponto que gostaríamos de destacar a respeito do contrato narcisista, evidencia-se um aprisionamento do sujeito que sua interação com o grupo familiar e o registro 
sócio-histórico pode promover. Na mesma medida em que é a associação ao conjunto que permite ao sujeito apropriar-se de um discurso, historizar-se e ganhar autonomia frente ao suporte parental, este mesmo registro pode promover um aprisionamento radical do sujeito, que tendo seu lugar fixado a representações sociais pré-estabelecidas, não encontra, no discurso do meio, possibilidade de conquistar sua autonomia frente aos significantes que lhe são atribuídos.

Pelos elementos do contrato narcisista encontramos o que positivamente vincula os sujeitos do conjunto entre si e ao discurso social. No entanto, este contrato tem um contraponto, aquilo que deve ser deixado de fora, indiscriminado para que o contrato possa acontecer. Trata-se do que Kaës denominou como pacto denegatório.

Chamo de pacto denegatório a formação intermediária genérica que, em qualquer vínculo [...] conduz irremediavelmente ao recalque, à recusa, ou à reprovação, ou então, mantém no irrepresentado e no imperceptível o que pudesse questionar a formação e a manutenção desse vínculo e dos investimentos de que é objeto. Pode-se, pois, considerar o pacto denegatório como um dos correlatos do contrato de renúncia, da comunidade de realização do desejo e do contrato narcísico. É o seu reverso e o seu complemento [KAËS, 1991, p.27].

Nessa relação reencontramos a realidade psíquica como fundamental para o estabelecimento do vínculo. O pacto denegatório, como o reverso dos demais vínculos entre sujeitos, refere-se justamente ao que deve permanecer de fora, no registro inconsciente, para que as relações se instituam. Esse material deixado de lado pode ser de duas naturezas: a de material recalcado, que não pode vir à consciência por apresentar um risco à manutenção dos vínculos (tais como impulsos agressivos ou a sexualidade erótica); a de material originário ou primário, que deve se localizar fora por ser irrepresentável, por se manter sob o funcionamento primitivo em que a intersubjetividade ainda era metabolizada segundo princípios pré-edípicos. O pacto repousa sobre a instituição social, e esse material, deixado de fora das relações entre os sujeitos, é depositado na instituição enquanto conjunto, que agora 
podemos apreender não só como uma cadeia de sentidos, mas também como um novelo de não-sentidos. Esse material se manifesta, tal como no sujeito, na forma de sintomas que extrapolam esta ou aquela relação no interior da instituição. Nosso interesse em relação ao pacto denegatório se refere a esse depósito do recalcado e ao seu retorno. Analista e analisando depositam no setting analítico as partes recalcadas de sua relação ao entrarem num processo de análise. Numa instituição onde analista e analisando são passíveis de outros vínculos, são esses outros vínculos que são englobados pelo pacto denegatório - pois de outra maneira não poderia instituir-se a relação analítica. Apesar da inevitabilidade desse recalcamento, o analista deve estar atento ao retorno desse recalcado para que ele não se manifeste em atos, mas possa ser trabalhado pelas intervenções do analista. Continuaremos a explorar um pouco mais estas questões acerca das denegações, na medida em que elas nos apontam para uma outra relação importante em nossa discussão: a relação entre o sujeito e a instituição e a organização psicanalítica.

\subsection{O ENQUADRE PSICANALÍTICO COMO INSTITUIÇÃO E COMO ORGANIZAÇÃO}

Ao delimitarmos o conceito de instituição e organização, e a relação do sujeito com os respectivos mecanismos psíquicos envolvidos, chegamos ao seguinte entendimento: uma mesma organização, onde se inseriria o atendimento de orientação psicanalítica, pode ser constituída por mais de uma lógica institucional, sendo no mínimo duas, a sua lógica predominante e a lógica psicanalítica. Esse entendimento merece nossa atenção, pois nos coloca as seguintes questões: como a instituição psicanalítica se faz presente nesse contexto? Como ela tensiona, ou não, com a lógica institucional que descrevemos?

Comecemos por tentar responder a primeira pergunta. Tendo como referência a clínica, que está na base da construção da instituição psicanalítica, Bleger (1988, p. 312-3) oferece-nos a seguinte compreensão: 
Uma relação que se prolonga durante anos, com a manutenção de um conjunto de normas ou atitudes, não é outra coisa senão a própria definição de instituição. O enquadramento é, portanto, uma instituição, dentro de cujos parâmetros ou no bojo da qual ocorrem fenômenos a que denominamos comportamentos.

No enquadramento da situação analítica que encontramos sua institucionalidade. É ele que se mantém, é ele que postula uma série de condutas esperadas por parte do analista e do analisando, é ele que dá sentido às ações dos atores na cena analítica. Na medida em que o enquadre configura-se como uma instituição, sua referência deixa de ser o conjunto dos sujeitos envolvidos, analista e analisando, e passa a referir diretamente aos ideais postulados pela Psicanálise. A instituição só torna-se questão para os sujeitos do conjunto quando esta falha e se faz presente, como aponta Bleger (1988, p.313):

O enquadramento se mantém e tende a ser mantido (ativamente por parte do psicanalista) como invariável; enquanto existe como tal, fica como que inexistente, ou não é levado em conta, do mesmo modo que as instituições ou relações que só se dão a perceber quando falham, se obstruem ou deixam de existir.

Retomamos aqui o final do tópico anterior, quando tratamos da importância dos aspectos denegados para a formação dos laços de um conjunto. Entretanto, com Bleger e a partir da compreensão da instituição psicanalítica, damos ênfase agora apenas para os aspectos mais primitivos e indiscriminados das denegações, em detrimento das denegações oriundas do recalque. Encontramos sobre este fundamento das instituições a seguinte proposição de Bleger (1988 p. 313-4):

As instituições e o enquadramento sempre se constituem num "mundo fantasma”: o da organização mais primitiva e indiferenciada. O que sempre está só é perceptível quando falta; [...] O que organiza o ego não são apenas as relações estáveis com os objetos e instituições, mas as frustrações e gratificações ulteriores com os mesmos. Não há percepção do que sempre está. A percepção do objeto que falta e do que gratifica é posterior; o mais primitivo é a percepção de uma "incompleteza". O que existe para a percepção do sujeito é aquilo cuja experiência lhe mostrou que lhe pode faltar. Em contrapartida, as relações estáveis ou imobilizadas (as não-ausências) são as que organizam e mantém o não-ego e formam a base para estruturar o ego em função das experiências frustrantes e gratificadoras. Que não se perceba o não-eu não implica sua não 
existência psicológica em termos da organização da personalidade. O conhecimento de algo só se dá na ausência desse algo, até que ele se organize como objeto interno. Mas o que não percebemos também existe. E este "mundo fantasma” existe depositado no enquadramento, ainda que o mesmo tenha sido rompido, ou precisamente por isso.

A formulação de Bleger acerca desse "mundo fantasma” depositado no enquadre, como possibilidade de existência daquilo que não somos capazes de perceber, intensifica a importância do enquadre, e, mais precisamente para nós vale destacar, da instituição, como base para que o próprio ego possa se estruturar. Organizando o não-ego, as instituições, e no caso da Psicanálise, o enquadre, permite que o ego estruture-se, e a partir do reconhecimento das faltas possa ocorrer uma organização da personalidade. O central, nesta observação do enquadre como depósito do não-ego, é entender que a psicanálise depende tanto daquilo que aponta a falta e promove mudanças, quanto daquilo que deve-se manter imóvel e institucionalizado. “A simbiose com a mãe (a imobilização do não-ego) permite à criança o desenvolvimento do seu ego; o enquadramento tem a mesma função: serve de sustentação, de marco, mas só chegamos a vê-lo - por ora - quando se rompe.” (BLEGER, 1988, p. 314-5).

O enquadre permite que, através de um pacto denegatório, uma aliança entre as partes psicóticas do analista e do analisando possa se estabelecer. Essa aliança, apesar de necessária, pode também trazer efeitos negativos e contrários a uma proposta analítica, uma vez que, além do enquadre, temos como maior ideal psicanalítico e a regra fundamental de associação livre. O enquadre, como expõe Bleger (1988, p. 316), constitui-se na mais perfeita compulsão à repetição durante a análise, pois além de se repetir por parte do paciente é também protegido pelo próprio analista. A instituição psicanalítica tem assim a condição ímpar de tensão interna entre os ideais que postula, uma vez que enquadre e regra fundamental, pilares de sua instituição, ao mesmo tempo em que dependem um do outro, apontam para sentidos opostos.

O desequilíbrio entre estas forças faz ruir a Psicanálise. Sem o enquadre claro e protegido pelo analista, os processos analíticos não podem se estabelecer, não há 
transferência, nem sequer possibilidade de uma organização do ego. Em contrapartida o enquadre inquestionável promove uma simbiotização nociva entre analista e analisando que impede qualquer atualização. Se retornarmos agora à nossa segunda pergunta acerca da tensão entre a instituição psicanalítica e as demais intituições/organizações, temos esta interação desfavorece o equilíbrio entre enquadre e regra fundamental. Nas demais organizações e instituições o aspecto da constância é mais intenso e reforça o aspecto simbiótico do enquadre psicanalítico. Devemos, então, estar mais atentos neste contexto a como trabalhar essa simbiose a ela não tomar conta de todo o processo e impedir qualquer ação analítica. Sobre a dessimbiotização, Bleger (1988, p. 322) faz as seguintes considerações:

\begin{abstract}
A dessimbiotização da relação analista-paciente só é alcançada com a análise sistemática do enquadramento no momento preciso. E com isso nos confrontaremos com as resistências mais tenazes, porque não se trata de algo reprimido, mas clivado e nunca discriminado; sua análise abala o ego e a identidade mais madura atingida pelo paciente. Não se interpreta o reprimido; cria-se o processo secundário. Não se interpreta sobre lacunas mnêmicas, mas sobre o que nunca fez parte da memória. Não se trata tampouco de uma identificação projetiva; é a manifestação do sincretismo ou a "participação" do paciente.
\end{abstract}

Nosso maior problema técnico para a inserção da psicanálise nas organizações fica sendo não naquilo em que ela tenciona com essas organizações, mas naquilo que ela se aproxima. Analisar o enquadramento dentro de uma organização é analisar também processos da própria organização. Compulsão à repetição e imobilidade do enquadre, por estarem vinculadas a perpetuação das instituições e manutenção do conjunto, são muito mais rígidas e compartilhadas por outros atores do conjunto que por identificação, ampliam ainda mais a resistência a mudança. Mesmo quando a análise desses processos é possível e precisa, o abalo que sofre o ego também se torna muito mais severo. "O enquadramento faz parte do esquema corporal do paciente; é o esquema corporal na medida em que o mesmo ainda não se estruturou e discriminou [...]: é a indiferenciação corpo-espaço e corpo-ambiente”. (Bleger, 1988, p.322). Para lidar com esses aspectos de indiscriminação radical o analista deve estar o 
tempo todo muito atento sobre seu próprio ego e sobre seus próprios processos de discriminação. Só estando seguro de sua própria posição o analista pode aceitar este depósito arcaico de seus pacientes sem mascará-lo. Somente se dispondo a acessar sua própria parte psicótica o analista pode analisar o próprio enquadramento. Uma última vez recorremos a Bleger (1988, p.323):

O analista deve aceitar o enquadramento que o paciente traz (que é o "meta-ego" do mesmo), porque neste encontra-se resumida a simbiose primitiva não resolvida; mas temos que afirmar, ao mesmo tempo, que aceitar o meta-ego (o enquadramento) do paciente não significa abandonar o próprio, e, em função disto, torna-se possível analisar o processo e o próprio enquadramento transformado em processo. [...] a relação analista-paciente fora do enquadramento rigoroso [...], bem como as relações "extra-analíticas", possibilitam o acobertamento da transferência psicótica e permitem o "cultivo" do "caráter" psicanalítico [paciente excessivamente padrão]. [...] Tanto a ruptura do enquadramento como sua manutenção ideal ou normal constituem problemas técnicos e teóricos, mas o que altera fundamentalmente toda possibilidade de um tratamento profundo é a ruptura que o psicanalista introduz ou admite no enquadramento. $O$ enquadramento só pode ser analisado dentro do enquadramento, ou, em outros termos, a dependência e a organização psicológica mais primitiva do paciente só podem ser analisadas dentro do enquadramento do analista, que não deve ser ambíguo, nem cambiante e nem alterado.

Ao avaliarmos a Psicanálise como instituição, observamos que sua inserção em contextos organizacionais outros tem como efeito uma distorção em seus ideais. Essa distorção é fruto, não de um abafamento da psicanálise, mas de um desequilíbrio de forças entre seus aspectos conservadores e inovadores, necessários para que possa emergir o sujeito do inconsciente. Institucionalmente, verificamos que a Psicanálise depende de seus herdeiros, os psicanalistas, para que não se torne outra coisa no interior das organizações, a custo de uma disposição bastante intensa em analisar a contratransferência e os aspectos mais arcaicos de nossa própria personalidade. 


\subsection{TRANSFERÊNCIA E VÍNCULO INSTITUCIONAL -}

\section{DESAFIOS PARA O ANALISTA}

Percebemos que a dimensão institucional é parte indissociável do processo de constituição do sujeito e condiciona as etapas mais remotas da formação do psiquismo. Encontramos também algo no psiquismo que escapa a esse processo, uma dimensão totalitária e indiferenciada que se mantém pelo funcionamento do inconsciente, sendo o próprio fluxo de representações-intenções-afetos que são o inconsciente. Esse desejo de totalidade, baseado em um registro onipotente que continua operando no inconsciente, é a fonte da transferência. No desenvolvimento da psique, este registro só pode ser abandonado por via da instituição social, que promove a socialização da psique e possibilita a mudança de objetos. É a mudança de objeto, que ocorre de maneira magmática, fazendo coexistir diversas representações distintas e idênticas, que faz com que as coisas e os indivíduos tomem o lugar dos “objetos” e que os signos privados dêem lugar a uma linguagem pública. A sociedade institui o indivíduo e em troca lhe dá acesso à sua rede de significações. O indivíduo, por sua vez, em sua imaginação radical e singular, pode romper com os modelos identificatórios da sociedade e promover o novo. Com o caminho percorrido até agora, delimitamos o conceito de instituições e organizações sociais a partir dos processos psíquicos, descrevemos a importância das instituições sociais na constituição das relações objetais, assim como o quanto essas relações são complexas entre os sujeitos ligados pela e na instituição.

Chegamos a um retrato um pouco mais complexo do problema que pretendemos abordar. Se pretendermos pensar como se dá a atuação do psicólogo clínico que atua dentro de uma organização atravessada por instituições heterogêneas, ou seja, inserido nesse conjunto, devemos supor que o profissional estará sujeito a todas as condições que acabamos de expor. Aqui podemos definir duas das condições especiais do atendimento analítico em instituições: a potencialidade da instituição de operar na realidade psíquica, e a relação entre 
analista e analisando inserida numa relação com os demais membros do conjunto e com uma mesma institucionalidade. Quando o analista atua como terapeuta da organização, as representações e relações transferenciais em sua relação com o analisando não estão isentas das suas relações com a organização/instituição. A relação analista-analisando estabelecida é atravessada no por esta dupla relação: do sujeito com a instituição e do sujeito com o conjunto de sujeitos ligados na e pela organização. Além disso, há a relação entre a instituição psicanalítica e a organização e demais instituições. Fazer Psicanálise nas organizações exige do psicanalista que ele esteja implicado com os ideais da Psicanálise, o que no caso da prática clínica implica em uma disposição a exposição bastante intensa, devido aos aspectos mais arcaicos do psiquismo depositados na organização. Trata-se de uma disposição a se desestruturar para analisar seu paciente e o enquadre, no caso a organização, que sustenta a ambos. Todas essas condições têm desdobramentos importantes, que procuramos localizar ao longo de nossa argumentação. 


\section{Casos institucionais, casos clínicos}

Após o desenvolvimento de nossa investigação conceitual acerca da prática psicanalítica nas instituições, propomo-nos agora ao exercício de discutir o resultado deste trabalho em algumas situações reais de sua expressão. Para tanto, trabalharemos neste capítulo sobre a análise de casos clínicos que ocorreram em contexto organizacional, retomando e pretendendo dar nova substância às discussões teóricas que desenvolvemos até o momento. Os dois casos abordados ocorreram em duas organizações distintas e foram por mim atendidos em um momento anterior ao início deste trabalho. Foram escolhidos justamente por sua condição problemática e condensam neles a maioria dos impasses que nos levaram a produção deste trabalho, que chega agora ao seu momento de conclusão e elaboração clínica. Trata-se, então, de um retorno à nascente desse trabalho, pois esses atendimentos fazem também parte das inquietações que nortearam nossa investigação metapsicológica.

Para cumprirmos a tarefa de analisar os casos em sua ligação com o contexto institucional das organizações adotaremos a seguinte estratégia: em cada caso, inicialmente discutiremos a organização e a configuração do setting de atendimento. Em um segundo momento, abordaremos como os casos se desenvolvem dentro da dinâmica estabelecida.

\subsection{O CURSINHO PSICO-USP}

O primeiro caso ocorreu no Curso Pré-Universitário Psico-USP. Trata-se de um cursinho popular que tem como público alvo a população de baixa renda e com formação realizada em escolas públicas. Sua proposta é possibilitar o acesso desta população, historicamente excluída pelas desigualdades sócio-econômicas do país, à formação em um 
ensino superior de qualidade. O cursinho é coordenado e gerido por estudantes do Instituto de Psicologia da Universidade de São Paulo (daqui por diante IPUSP). Além das atividades pedagógicas, o cursinho conta com um serviço de psicologia, no qual os alunos podem tratar de quaisquer demandas que julguem poder contar com a ajuda de um psicólogo. Os atendimentos podem acontecer na modalidade de plantão, em que os alunos procuram o atendimento em um horário de permanência dos psicólogos, ou de maneira regular, em que os atendimentos são agendados. Esses atendimentos não têm prazo determinado de duração, porém são limitados pelo tempo de vínculo do estudante com a instituição. Os atendimentos são realizados por uma equipe formada por alunos de graduação do instituto e estão ligados a um serviço do IPUSP, pelo qual são supervisionados.

Para discutirmos a influência dessa organização na constituição da situação analítica e da transferência, refinemos um pouco mais nossa compreensão das esferas organizacionais e institucionais em que se configuram os atendimentos. Trata-se de um serviço de psicologia inserido em um cursinho popular, por sua vez inserido em um Instituto de Psicologia e em uma Universidade. Cada uma dessas organizações, e as instituições que representam, sugere determinadas cenas fantasmáticas aos seus atores, se encontrando amarradas à situação analítica e à transferência, que se constituirão sobre elas. Nosso intuito é explorar como as representações e cenas fantasmáticas desse contexto, institucional e organizacional, interferem na manifestação da transferência.

A entrada na universidade é o principal objetivo dos alunos do cursinho. Dentro dessa proposta, a entrada na USP, para a maioria dos alunos, significa a realização plena desse projeto. Trata-se do resultado de uma dupla referência à USP como instituição. Externa e independentemente ao contexto organizacional do cursinho, a USP detém grande prestígio quanto à excelência de seu ensino, além de ser financeiramente viável aos alunos do cursinho por ser uma universidade pública. Internamente à organização cursinho, além de, no aspecto 
organizacional, acolhê-lo em seu espaço físico, a USP é uma das instituições que dão sentido a sua existência, estando presente em seu próprio nome. A referência de excelência de ensino do cursinho está vinculada a USP enquanto instituição, sendo que seus professores estão se formando ou se formaram nesta universidade. O investimento pessoal do aluno no curso préuniversitário e no pertencimento a este conjunto, em especial na relação com seus professores, amplia o investimento positivo em relação à USP. Pensando, também, a partir de minha posição, psicólogo do cursinho e estudante de graduação na época, a universidade constituíase como um outro quadro de referência. Pertencíamos à organização USP. Tratava-se de nosso cotidiano, ambiente onde formação profissional, acadêmica e também pessoal construía-se, acolhidas pela referência universitária.

O IPUSP tem com o curso pré-universitário uma relação organizacional e institucional. No aspecto organizacional, o IPUSP cede o prédio em que funciona o curso, tendo por isso o poder de exigir certas regras de funcionamento. Para o aluno do cursinho é a via pela qual se realiza uma entrada na universidade. O cursinho funciona no bloco de aulas do instituto e permite o acesso a uma parcela da vida universitária: pessoas, espaços e relações. Com o cotidiano, cria-se uma familiaridade nas relações entre os estudantes do cursinho e do IPUSP, em especial com os universitários que também são funcionários do curso pré-universitário. No aspecto institucional, a principal influência do IPUSP como fonte de significações, ideais e conduta está no fato da coordenação do cursinho ser ocupada por estudantes do instituto. Esse viés, presente na origem desta organização, promove uma relação peculiar do aluno do cursinho com a Psicologia. A instituição Psicologia dá sentido ao IPUSP, uma vez que a organização existe para cumprir a função de ensino, pesquisa e extensão em Psicologia. Porém o Psico, presente no nome do curso pré-universitário faz apenas referência indireta a Psicologia, pois se refere ao IPUSP. A relação do aluno do cursinho com a Psicologia, por esta via, sofre uma distorção. Apontamos em nossa discussão anterior sobre a 
constituição do contrato narcisista, a importância do mito de origem como um registro de verdade no discurso. Esse mito sustenta o vínculo entre os sujeitos do grupo por libertá-los da dependência das verdades individuais, mas exige dos sujeitos sua perpetuação. Por esse processo, o pertencimento ao Curso Pré-Universitário Psico-USP está vinculado a transmissão por seus componentes (não só alunos, mas funcionários também) de um discurso em que a Psicologia está impregnada de uma ideologia transformadora, voltada para mudança das desigualdades sociais e, mais que isso, que ela é detentora potencial desse poder. Para o estudante do cursinho a Psicologia insere-se, dessa maneira, não apenas por suas representações mais tradicionais relacionadas seja ao tratamento ou à avaliação, e também não apenas na familiaridade das relações cotidianas, mas também como detentora desse poder de transformação social, potencializando uma representação idealizada do psicólogo.

O aluno de psicologia responsável pelos atendimentos tem em sua posição, um duplo vínculo organizacional, com a conseqüente sobreposição de representações institucionais. Como psicólogo do cursinho, e considerando a dinâmica apresentada, a Psicologia transforma-se em um instrumento poderoso, que instiga suas fantasias onipotentes. Como estudante de graduação do IPUSP, a Psicologia refere-se à formação de uma identidade profissional em seus primeiros passos e às inseguranças atreladas a esse processo. Para que alguma diferenciação se estabeleça entre este estudante de psicologia e os demais, que cumprem outras funções no cursinho, àqueles que cuidam dos atendimentos não participam das demais atividades com os alunos do cursinho e mantém uma postura mais reservada nos corredores e demais atividades coletivas.

Em relação às demais institucionalidades que atravessam Curso Pré-Universitário, estas trazem também uma referência de enquadre, de papéis e de funções que se sobrepõem ao da situação de atendimento. Trata-se de uma organização que se legitima pelo o ensino e pela transmissão de conhecimentos. A organização tem, por isso, uma forte influência em 
seus ideais e condutas da Pedagogia, e da Escola ${ }^{25}$, instituições na qual as relações giram em torno do par professor-aluno. Para o aluno do cursinho, este é uma extensão da escola que conheceu até então, e é a partir das relações Escolares que ela explora o cursinho e também o atendimento psicológico. É para aprender algo de si que ele procura o psicólogo, ${ }^{26}$ e não para tratar algum sintoma. A principal implicação dessa troca de referência institucional está no fato do professor ser muito mais familiar ao aluno do que o médico, e dessa maneira uma figura muito mais próxima à relação interpessoal.

Além da relação professor-aluno, devemos retomar também a questão de se tratar de um cursinho popular, com uma ideologia de transformação social. A partir disso, o trabalho faz-se não só exercício profissional, mas também visão de mundo. O fato de o cursinho ter sido constituído e ser gerido por estudantes de Psicologia intensifica a internalização dos ideais institucionais por parte dos responsáveis pelos atendimentos, também estudantes de Psicologia. Essa transmissão é facilitada por uma identificação com os fundadores e com aqueles que ocupam as funções de liderança. No meu caso esta internalização tem ainda o componente adicional de que minha vinculação com o cursinho precede o momento em que

\footnotetext{
${ }^{25}$ Referimo-nos aqui a Escola com letra maiúscula por nos referirmos a ela como instituição, como ensino formal, e não a uma escola específica enquanto organização. Também a diferenciamos da Pedagogia porque a primeira está relacionada a uma estrutura historicamente construída de transmissão do conhecimento e a segunda configura-se como de conhecimento que estuda esses processos de transmissão. Ambas instituições tem sua intersecção nas organizações que, tal como o cursinho, realizam os processos pedagógicos em estruturas escolares.

${ }^{26}$ Era comum os alunos que procuravam o atendimento anunciarem que sabiam que o psicólogo não curaria suas mazelas, mas esperavam que fosse capaz de ensiná-los a resolverem os problemas sozinhos. Se nos consultórios muitas vezes as pessoas procuram no psicólogo, um médico que trate de seus problemas como sintomas que devem ser extirpados a partir de seu saber de especialista, no cursinho o psicólogo é procurado como um tutor, um professor, que resolveria os problemas pela transmissão de seus conhecimentos, pelos ensinamentos de lições que levariam a superação das dificuldades.
} 
comecei a realizar os atendimentos, tendo ocorrido anos antes e por meio de outras funções na organização.

Pela ideologia explícita que defende, temos ainda que qualquer estudante do cursinho, para o estudante de psicologia que trabalha pelo Psico-USP, corresponde a um perfil de população excluída, selecionada por uma vulnerabilidade sócio-econômica. Os estudantes do cursinho, no entanto, nem sempre se reconhecem nessa proposição identitária, apesar desse processo ser favorecido tanto pela seleção dos alunos que entram na instituição, quanto pelas ações do cursinho, que afirma sua ideologia não só em seus princípios, mas também em suas práticas cotidianas. Ao propor atividades nas quais realizam a crítica e o questionamento dos problemas da educação no país, reafirma o lugar onde enxerga seus alunos. Essa identidade forjada pela instituição não é exclusiva nem favorecida apenas nos alunos, acontecendo também entre os funcionários, porém para estes não há mecanismos organizacionais (não há uma seleção sócio-econômica, por exemplo) que determinem tal lugar.

Feito este retrato do cenário que atravessa toda a instauração do setting de atendimento, conheçamos o caso de Mara.

\subsubsection{O CASO MARA ${ }^{27}$}

Atendi Mara no serviço de Plantão Psicológico do Curso Pré-Universitário Psico-USP, quando ainda era aluno de graduação do IPUSP. Quando procurou o atendimento psicológico, Mara queixava-se de um forte estresse a que estava submetida por conta de uma acusação, a que respondia judicialmente, por um conflito com seu ex-chefe, em sua primeira experiência profissional. Relatou que ele havia se insinuado sexualmente e, por não ela ter correspondido ao assédio, havia sido colocada na situação de acusada, culpabilizada por negligências no

\footnotetext{
${ }^{27}$ Nome fictício.
} 
trabalho. Neste processo a que respondia a questão sexual não era abordada, pois não tinha como prová-la. Reprimido do processo, o caráter erótico imposto por seu antigo chefe em sua relação de trabalho, acabava recalcada em Mara, que sofria por não conseguir significá-la. Dizia:

- Às vezes acho que é culpa minha mesmo tudo isso, que eu devia ter percebido...

- O que é que você poderia ter percebido?

- Não sei, acho que eu fui muito boba...

- E o que você acha que poderia ter feito?

- Não sei... não sei... acho que nada... mas sempre que eu lembro desse problema [do processo] eu me sinto assim...

Pela assimetria de poderes e pelo não reconhecimento dessa violência, a erotização acontece de uma maneira excessiva e inesperada, em sua primeira relação de trabalho. Apesar de a sexualidade estar presente em toda vinculação organizacional, como já abordamos, tratava-se de uma sexualidade não partilhada, de uma "confusão de língua” ${ }^{28}$ na qual Mara se viu sem defesas para lidar com o interesse erótico do antigo chefe. Relatava-me angústias, tinha seu sono e sua alimentação perturbados, sentia dúvidas sobre o quanto era culpada pelo que ocorria, por não ter percebido e se afastado antes. Suas sensações eram intensificadas pelo desdobramento judicial, no qual era a acusada e na qual o assédio não era reconhecido. Durante os atendimentos houve a possibilidade do reconhecimento dessas angústias, e aspectos eróticos envolvidos nesse conflito tiveram algum espaço para emergir e ganhar alguma significação, o que permitiu um alívio dessas tensões. Depois de um mês, Mara, mais confiante, diz que está mais calma e consegue pensar as coisas sob outro ponto de vista, encerrando, temporariamente, o processo.

\footnotetext{
${ }^{28}$ Cf. Confusão de língua entre os adultos e a criança, in Obras completas, vol. IV.
} 
No início do segundo semestre, ela retorna ao plantão com uma nova queixa: havia se envolvido com um professor do cursinho e estava com problemas nesse relacionamento. Com seu professor, Mara se encontrava novamente em uma posição passividade em relação uma assimetria de poder frente ao seu parceiro. O componente erótico desta relação, entretanto, deixou de ser reprimido. Suas angústias sem nome, que perturbavam e não a deixavam dormir ou comer em seus primeiros atendimentos, transformaram-se em queixas acerca da falta de atenção de seu namorado/professor, em ciúmes das colegas de cursinho, em confusão acerca de seus interesses na relação. Mara expressava, nessa relação, indícios do reconhecimento de um desejo próprio, ainda que de maneira ambivalente. Desejava e se envaidecia por uma atenção especial de seu namorado/professor, ao mesmo tempo em que se enfurecia de ciúmes de outras alunas que o disputavam e o desprezava por não dedicar a ela atenção que desejava. Vivia essa confusão de sentimentos, ou oscilava entre uma posição e outra, a cada vez sinal que seu namorado/professor lhe dava. Durante esses atendimentos o principal foco de minhas intervenções esteve no reconhecimento de seus desejos, a cada circunstância, a cada evento.

- Sei que a Vilma ${ }^{29}$ tá afim dele. Eles acham que eu sou boba.

- E o que você faz?

- Eu fico de olho. Ela fica atrás dele, mas se eu falo alguma coisa ele se faz de desentendido. Na semana passada a gente foi estudar junto e ela ficava o tempo todo puxando assunto com ele.

\section{[...]}

- E se eles tiverem mesmo alguma coisa, o que você vai fazer?

- Aí eles vão ver. O Manoel ${ }^{30}$ também é esquisito. Cada hora ele está de um jeito. Quando eu estou atrás dele ele nem liga, nem me dá atenção. Aí de repente ele fica todo carinhoso. Já não tô mais agüentando isso...

\footnotetext{
${ }^{29}$ Nome fictício.
} 
Depois de algum tempo, o relacionamento entre Mara e seu professor terminou e os atendimentos, além da retornarem a queixa inicial (o processo a que ela respondia ainda estava em andamento), passaram a temas como a dificuldade de assumir escolhas frente à opinião dos outros e a necessidade da entrada no mundo universitário, da entrada na USP, como forma de auto-afirmação pelo reconhecimento social. Em seu discurso, Mara afirmava que a entrada na USP a livraria de todos os seus sofrimentos. Em relação aos problemas que a incomodavam, citava em especial o descrédito de um tio próximo, que não a considerava capaz e a quem mais desejava responder. Procurava cursos que oferecessem uma concorrência mais fácil, pautava sua escolha na necessidade dessa entrada. Sofria com a possibilidade de não passar. Nesse período, a representação institucional do universitário, que no cursinho ocupava o papel que Freud atribuía à figura do líder, tomava o lugar de seu ideal de ego. Acontecia, como pudemos definir com Enriquez, um processo de substituição, no qual o ideal passava a se localizar na idéia, presente na organização, do universitário. Essa substituição era partilhada com os demais estudantes do cursinho, pois era o ideal universitário que os reunia enquanto conjunto. Porém, Mara vivia esse ideal de maneira especialmente intensa, com a entrada na universidade representando a possibilidade de um enriquecimento mágico do ego, que se tornaria mais potente e mais livre pela apropriação de poderes, então, atribuídos à universidade. Pela passagem no vestibular o mana seria transferido a ela, que então tornaria tão onipotente quanto seu ideal. Diante deste processo, Mara percebia-se impotente no presente.

Durante essa etapa, os atendimentos eram agradáveis. Incomodamente agradáveis. Apesar da ansiedade e sofrimento nos assuntos tratados, minhas falas e intervenções surgiam espontaneamente, e me sentia como em uma relação cotidiana, familiar, o que passou a me

\footnotetext{
${ }^{30}$ Nome fictício.
} 
preocupar entre uma sessão e outra ${ }^{31}$. Passei a perceber também que apesar de Mara sempre aceitar minhas intervenções, elas cada vez menos repercutiam em qualquer mudança, seja em seu discurso, seja em sua postura em relação às questões, que se repetiam. Esse incômodo permaneceu até o final dos atendimentos, e minhas intervenções procuraram até aquele momento fazer com que ela pudesse enxergar a entrada na universidade de outra maneira.

O processo não culmina em nenhuma conclusão, mas encerra-se no tempo limite. $\mathrm{Na}$ última sessão, Mara me leva um presente, porém pede que eu só o abra depois que ela for embora. Aceito o presente e a instrução, e durante a sessão fazemos uma síntese do que havia sido trabalhado, resumindo aquilo que fora o processo. Ao final, ela agradece pela atenção e nos despedimos. O presente que ela havia me deixado era um pequeno bicho de pelúcia, e dentro da embalagem havia uma carta sua:

[...]eu não sou uma pessoa perfeita

Existem coisas que eu gostaria de não ter feito

Mas eu continuo aprendendo

E então eu tenho que te dizer antes de ir embora

Que eu só quero que você saiba

Eu achei uma razão pra mim, pra mudar o que eu costumava ser, o razão pra começar de novo e a razão é você.

Eu achei uma razão pra mostrar um lado meu que você não conhecia

A razão de tudo o que eu faço

E a razão é você!

Sua lembrança estará comigo para sempre. Obrigada do fundo do meu coração.

Sou surpreendido. Na carta, ao mesmo tempo em que declara um interesse amoroso, agradece pelas mudanças que havia alcançado por conta dos atendimentos e se despede. Não imaginava que este interesse estava ocorrendo e fiquei bastante apreensivo, imaginando que deveria ter captado algum sinal que deixara passar. A situação dos atendimentos ainda me era

\footnotetext{
${ }^{31}$ A familiaridade na relação trazia consigo o perigo da eliminação do estrangeiro, do estranho. Como coloca Endo (1997), “[...] é a presença do estrangeiro que, provocando o discurso, a palavra e a fala, provoca também a intimidade entre sujeitos”. As relações dentro de qualquer organização tendem a familiaridade, uma vez que tanto as regras organizacionais quanto as referências institucionais, estabelecem padrões de conduta esperados com o qual nos acostumamos.
} 
bastante nova, o que neste momento despertou muita dúvida sobre o que era despertado por Mara e o que trazíamos de nossas próprias fantasias e ansiedades. Nesse momento minha situação organizacional de aprendiz se sobrepunha à posição de terapeuta e me sentia desorientado, desapropriado de qualquer saber. A relação estabelecida por Mara invadia-nos, sem que pudéssemos discriminar sua transferência de nossas próprias defesas e recalques. Em nenhum momento me ocorrera que a questão erótica pudesse ter sido transferida para mim, e por isso minha surpresa com a revelação da carta.

Um dos elementos fundamentais para esta cegueira foi minha dupla vinculação, no setting terapêutico e com o cursinho, especificamente o pacto denegatório que esses vínculos me propunham. Como discutimos anteriormente, os elementos denegados são fundamentais para a manutenção dos vínculos. Trata-se do que deve ficar de fora da relação, e não do que pode estar fora. Na relação psicoterapêutica com Mara, o que era denegado era a expressão da sexualidade. De minha parte, reconhecer a transferência amorosa implicava em contratransferencialmente reconhecer em mim a expressão desse erotismo. Esse reconhecimento por sua vez teria como conseqüência o questionamento de minha conduta profissional, algo que minha identidade profissional em formação ainda não era capaz de suportar. Nosso pacto com Mara era este: para que nossa relação se constituísse como algo diferente de qualquer outra, cotidiana do cursinho, então deveríamos constituí-la como um mundo à parte da organização, inclusive do fator de que ela poderia favorecer um interesse erótico. E ao fechar da porta da sala de atendimento esse contrato implícito e inconsciente começava a vigorar. O problema foi que nossa, minha e de Mara, vinculação com o cursinho e com tudo que estava atrelado a ele, forçou sua entrada, emergindo na transferência. Nesse ponto temos a segunda denegação.

Minha vinculação positiva com o cursinho e com os ideais que ele representava me impedia de enxergar o que ele pudesse trazer de negativo às relações. Essa denegação era 
depositada no enquadre organizacional, na forma de regras que permitiam abertura para as experiências clínicas e escondiam o efeito negativo que a organização inerentemente produzia ao trabalho psicoterápico. Como conseqüência, a interpretação das angústias enfrentadas contratransferencialmente só encontrava como saída a localização do problema em mim mesmo e em minha condição de aprendiz, o que reforçava ainda mais a própria estrutura e organizacional. Tanto meu contrato com Mara, quanto minha vinculação ao cursinho, ao instituto e a universidade me aprisionaram, naquele momento, nessa hipótese, impedindo uma melhor análise da situação.

Do ponto de vista de Mara, a denegação implicava também em um não reconhecimento da sexualidade erótica dentro do setting. Não me reconhecer como o universitário a quem ela desejava se tornar, e sim apenas como seu psicoterapeuta, era o que a princípio depositava-se em nosso enquadre de mundo particular. Porém não há mundos particulares dentro das organizações. O IPUSP e seus representantes, em nossa relação, continuavam como provedores de seus sonhos e ideais. Se a situação analítica, como já abordamos anteriormente, favorece a transferência pela assimetria dos papéis em relação ao saber sexual, nossas posições institucionalizadas só faziam intensificar essa assimetria e, conseqüentemente, a transferência.

Depois do fim das sessões, na supervisão, realizada em grupo, contei o ocorrido. Depois de contar o caso, e passadas as primeiras considerações sobre minhas possibilidades de perceber ou não que aquela situação vinha ocorrendo, uma colega de equipe me conta que já sabia do interesse de Mara por mim. Minha colega, além do serviço de psicologia, trabalhava no serviço de informações sobre vestibulares e havia sido procurada por Mara, que confessou seu interesse, mas pediu segredo. Minha colega procurou orientação de nossa supervisora e ambas decidiram não interferir em meu atendimento com uma informação que Mara tinha escolhido não revelar a mim. Após me contar este pedaço da história que eu 
desconhecia, minha colega afirmou que ficava bastante desconfortável durante minhas supervisões (além de colegas, somos amigos) e que vivera um conflito bastante grande por ter de guardar este segredo. A diferença na expressão desta transferência é que o fato dela ter sido produzida e mantida não apenas pelo setting terapêutico, mas pelo organizacional, fez com que sua expressão também extrapolasse o enquadre analítico.

Descobri, após o fim do processo terapêutico, que minha surpresa frente à declaração amorosa de Mara teve condições específicas para ocorrer, que extrapolavam o enquadre terapêutico. Foi na e pela organização que Mara viveu sua transferência, mesmo quando esta se voltou para mim. Mara expressa em sua transferência o conflito, que apontamos em nossa discussão acerca do psiquismo nas massas, entre os interesses psíquicos da situação analítica e da organização, ou seja, o conflito entre o favorecimento da expressão do erotismo e sua repressão. A situação analítica despertava uma transferência erótica; a organização exigia o recalque desse erotismo para a manutenção dos papéis. Intensificada por esse conflito de ordem psíquica e institucional a transferência transbordou para a organização. A proibição de seu desejo encontrou, só assim, possibilidade de se expressar e ser compartilhada, como segredo e conflito que dividido com nossa colega permitiu que Mara vivesse sua transferência garantida não pelo enquadre do setting, mas pelo enquadre da organização. Diante de mim esse amor expressava-se como angústia sublimada, desejo de alcançar a universidade, que de tão ideal tornava-se inalcançável. Mara relatara a minha colega que vivia esta paixão durante a semana, mas quando começavam as sessões esquecia-se desse amor, só voltando a se ocupar dele depois dos atendimentos. Vivia-o de maneira platônica. Mesmo quando se declara, pede que sua carta seja lida apenas depois que a sessão estivesse encerrada e que não estivesse mais presente. Declara-se e agradece, pelo atendimento e por nossa presença em sua vida, que permitiu que ela vivesse esse amor. Enfim pode viver seu amor de maneira segura. Suas angústias foram depositadas no enquadre, que era organizacional sim, mas feito também de 
nosso corpo e do de nossa colega. Vivemos ambos uma parcela das maiores dificuldades de Mara, o peso do desejo proibido que não poderia ser contado e a culpa por não reconhecê-lo. Mara desenvolvia assim seu percurso neurótico, de um segredo não revelado (seu desejo recalcado pela violência vivida) a um ideal sublimado (sua relação com o ideal universitário) e um amor reprimido (sua transferência).

Tentemos, por fim, sintetizar nossa análise desta situação. Mara tinha como demanda, que a trouxe aos atendimentos, uma violência vivida (ou revivida) em sua relação com seu exchefe, uma invasão de um sexual do qual não podia dar conta. Tal violência pautou-se em uma assimetria de poderes absoluta, onde ainda terminou culpabilizada, em sua fantasia, por sua inaptidão em lidar com este sexual. Posteriormente, a condição assimétrica e ambivalente vivida com seu professor e seu psicólogo, produziu uma transferência erótica, como via de atualização de seus conflitos. O pertencimento ao cursinho permitiu que seu conflito encontrasse também uma via sublimada de expressão, materializada pela entrada na universidade, por uma entrada na USP. Pela entrada na USP a assimetria de saberes poderia ser eliminada, juntamente com seus conflitos, ou ao menos Mara poderia tomar posse do poder/saber a que estava submetida.

Do meu ponto de referência, vários fatores relacionados ao nosso pertencimento organizacional nublaram minha visão em relação ao processo de Mara. O papel de estudante de psicologia/terapeuta fez com que toda minha atenção fosse tomada por uma efetividade ou não das intervenções dentro do setting dos atendimentos. A partir de meu lugar de estudante, investido pelo poder de seu nome, acolhido pelos laços de seus membros, a USP constituía-se para mim tal como o grupo familiar, me fazendo herdeiro e exigindo, por mim, sua perpetuação. Por seu nome me tornava profissional e, procurando constantemente o aperfeiçoamento em minha prática, perpetuava sua história. Por essa relação de pertencimento ao conjunto, minha principal relação com a USP era a de um contrato narcisista, no qual a 
principal exigência era a de uma formação crítica e rigorosa. Ao considerarmos também o IPUSP, o pacto narcísico ganha mais uma dimensão, a de minha própria identidade de psicólogo. Meu pertencimento ao conjunto de psicólogos, em meu exercício profissional, extrapola a relação com a universidade, e acrescenta a esse contrato narcisista a crença nos benefícios e poderes da intervenção psicológica. Trata-se de um grupo ao qual não deixaria de pertencer mesmo depois de formado, e que fortaleceu nossa aderência ao seu ideal institucional. Frente à transferência erótica, o resultado deste duplo contrato foi que ele me levou questionar a excelência de minhas ações, o que estava de acordo com o contrato narcísico de pertencimento a USP, mas não minha identidade profissional, o que deveria ser denegado no contrato com o IPUSP. Também com características de um contrato narcisista, meu vínculo com o cursinho dificultou-me o reconhecimento da transferência erótica, porque esta significava um problema criado pelo choque entre o setting de atendimento e o cursinho; em minha vinculação com o cursinho, a expressão erótica deveria ser reprimida para que o atendimento se diferenciasse das demais relações cotidianas do cursinho, o que fazia com que no setting eu negasse o fato de que os mesmo mecanismos em jogo n organização estariam presentes durante as sessões.

Em relação à expressão da transferência, esta se espalhou pela organização. Seu trabalho mais rigoroso, como verdadeira intervenção analítica, dependia de um reconhecimento de pactos e contratos inconscientes com o conjunto organizacional que não foram possíveis à época, e que extrapolavam a individualidade de terapeuta e do setting terapêutico. Sugerimos, a partir da análise desse caso, que uma das condições necessárias, para que a prática psicanalítica, enquanto modelo de intervenção clínica, inserida em um contexto organizacional, ocorra, é a disponibilidade do terapeuta analisar e até mesmo por em xeque o seu pertencimento ao conjunto. Olhando o caso de fora, com a distância que o tempo nos ofereceu, parece mais fácil enxergar o quanto ele poderia se desdobrar numa transferência 
amorosa. Porém para preservar minha condição organizacional de profissionalismo, e institucional de psicólogo em formação, negava a possibilidade do sexual, a possibilidade de meu próprio interesse sexual que contratransferencialmente uma transferência erótica despertava. Um bom trabalho na transferência exigia que eu enfrentasse a possibilidade de ser um mau profissional, exigia que eu despojasse desse laço organizacional/institucional, para que então eu pudesse questionar o quanto a organização estaria colaborando para a manifestação da transferência e o quanto ela poderia estar se manifestando não só no setting analítico. Este despojamento, ainda assim não é uma condição suficiente, pois o trabalho na transferência em organizações por vezes será inviabilizado por sua expressão difusa e fora do alcance do psicanalista. Para enfrentar esta desvantagem o psicanalista deverá enxergar seu setting não apenas em seu contrato com o paciente e em seu local de atendimento, mas em toda experiência que ele e seu analisando tiverem com a organização.

Podemos discutir também a partir deste caso as condições da atuação psicanalítica. A psicanálise precisa de um reconhecimento que permita ao psicanalista trabalhar a transferência, pois a resistência a suas intervenções pode partir das relações organizacionais e não do paciente - assim que elas comecem a ameaçar os vínculos que unem o conjunto organizacional ou ataquem os ideais institucionais que o constituem, serão prontamente rechaçadas ou reprimidas. A organização nesses momentos minará o campo analítico e cabe ao psicanalista a clareza de compreender se o que deve ser interpretado é a reação do paciente ou da organização. O reconhecimento do discurso psicanalítico é necessário caso a interpretação volte-se para a organização, para que o campo da intervenção psicanalítica possa de alguma maneira ser sustentado e não abafado pela organização. Mesmo diante de um reconhecimento do discurso psicanalítico, quando este se chocar com os laços que mantém a organização e, especificamente como foi nesse caso, ligam o psicanalista a organização, as intervenções serão prejudicadas. O que concluímos dessa dinâmica é que apesar do olhar 
psicanalítico instituir uma prática diferenciada no interior de uma organização, uma verdadeira análise nunca pode ser plenamente garantida em uma organização.

Se não podemos esperar de uma prática psicanalítica em organizações que ela seja sempre análise (ou talvez devamos nos contentar que ela nunca será análise), podemos enumerar uma segunda característica do contexto organizacional/institucional que se apresentou como uma vantagem: a potencialidade de elaboração inconsciente envolvida no pertencimento às organizações e a relação com as instituições. A transferência, ao ocorrer nas organizações, é afetada por suas ligações inconscientes, pelas instituições, e podem assim promover elaborações, além de oferecer elementos muito mais complexos para a instauração da transferência. No caso de Mara, seus fantasmas acerca do traumático e do sexual puderam ser atuados transferencialmente tanto comigo, quanto com seu professor e de maneira sublimada em seu propósito de entrada na universidade. A diferença na relação que teve comigo, seu psicólogo, em relação a que teve com seu professor, por quem também se apaixonou, permitiram que a relação de perigo e desejo implicada na assimetria das relações ganhasse novas matizes. Seu desejo pôde então ganhar vias de expressão, salvo da violência que experimentara com seu ex-chefe, permitindo novas significações. Se não foi suficiente para resolver seu conflito frente ao sexual, ao menos permitiu que o experimentasse de maneiras diferentes e ganhasse assim uma perspectiva que talvez só fosse possível com um tempo muito maior de análise, dado que no caso de uma análise convencional o único suporte transferencial existente seria seu psicólogo e o setting analítico. Devemos ressaltar, entretanto, que mesmo frente a essa possível vantagem do enquadre organizacional, enfrentamos a dificuldade de fazer dela intervenção. São muito complexas as relações dentro de uma organização e são múltiplas as instituições que a atravessam. Se podemos ponderar nossas ações quando a transferência é voltada diretamente para nós por uma análise de nossa contratransferência e de nossos próprios vínculos com o conjunto, e fazer com que esta seja 
benéfica ao processo, não podemos garantir que a transferência espalhada pela organização seja trabalhada da mesma maneira. Podemos nos reposicionar dentro da dinâmica organizacional, mas não podemos mudar essas relações a cada caso. Fica esta sendo uma questão que pudemos formular, mas que não daremos conta de responder aqui. Trabalhemos agora sobre outro caso que traz uma nova vertente da relação com as instituições e com a organização.

\subsection{O SERVIÇO DE ORIENTAÇÃO PROFISSIONAL:}

Os dois próximos casos aconteceram no Serviço de Orientação Profissional (SOP) do IPUSP, serviço que oferece orientação para escolha de carreiras de ensino superior, escolha de escolas técnicas e orientação sobre mudanças de carreira para universitários, profissionais ou aposentados. Os atendimentos ocorrem na clínica-escola do IPUSP. Além dessas orientações o serviço oferece uma especialização para formação de orientadores e consultoria para organizações.

Os atendimentos podem ser realizados por alunos da graduação do IPUSP, em estágio obrigatório, ou por alunos da especialização em orientação profissional. Os atendimentos são supervisionados pela equipe de psicólogos do serviço. Os usuários do SOP são atendidos inicialmente em uma triagem, que na maioria dos casos consiste em um único atendimento, e a partir dela são encaminhados para grupos de orientação ou para uma terapia breve com foco na orientação profissional. A terapia breve dura, em média, dez semanas, com encontros semanais. Minha inserção dentro do SOP, no período em que ocorreram os casos que serão apresentados, foi como aluno da especialização. Tinha como atividades as aulas teóricas, os atendimentos de triagem e a terapia breve com foco em orientação profissional. As 
orientações ocorriam nas mesmas salas nas quais realizei meus estágios para o aprendizado da prática psicoterápica, na clínica escola do instituto de psicologia.

Temos no SOP, tal como no curso pré-universitário, a USP e o IPUSP como importantes instituições de referência. No caso do SOP, entretanto, esta relação tem outra natureza. O SOP pertence tanto a universidade quanto ao instituto também como organização. Isto faz com que o SOP seja de fato USP e IPUSP, não apenas como referência institucional, mas efetivamente enquanto conjunto.

A universidade, no caso do SOP, além de emprestar sua credibilidade ao serviço, o aproxima ainda mais do contexto escolar. A orientação profissional já é atravessada pela Escola $^{32}$ por estar historicamente vinculada às mudanças de etapa desta instituição (a principal demanda da orientação está relacionada à escolha realizada na transição do ensino médio para o ensino superior). O fato de o serviço ser oferecido pela universidade, organização inserida na série escolar, alimenta ainda mais esta associação nos usuários.

Minha vinculação ao SOP, por sua vez, era também atravessada pela relação que mantinha com o IPUSP. Por meu pertencimento ao IPUSP ser anterior à relação propiciada pelo curso de especialização, por vezes me via atuando ideais e tendo condutas que, apesar de pertinentes à psicologia, estavam fora do campo da orientação profissional. Ainda que por vezes divergisse das condutas da organização, me sentia amparado institucionalmente pelos ideais que me fizeram, anteriormente, sentir pertencente ao IPUSP. Essa dinâmica gerava impasses tanto para minha atuação quanto para meu pertencimento organizacional. Em relação aos atendimentos, estes sofriam distorções pelo atravessamento de minhas representações de atendimento psicoterápico. Em relação ao meu pertencimento organizacional, a relação com o conjunto encontrava-se fragilizada, pois não me identificava com os representantes da organização e sim com a instituição Psicologia que era apenas uma

\footnotetext{
${ }^{32}$ Usamos aqui a letra maiúscula por nos referirmos a instituição Escola, e não a uma organização específica.
} 
das instituições que sustentava o SOP. A principal conseqüência dessa distorção é que me sentia em uma posição de autoridade e responsabilidade em relação às instituições pela qual me guiava, por estas não serem mediadas nem limitadas pela relação com o conjunto. Tratava-se de uma relação diretamente institucional ${ }^{33}$, não mediada por aquela organização.

Vejamos agora, dentro desse contexto, como se desenvolveram os atendimentos de Miltom e Clara.

\subsubsection{O CASO MILTOM ${ }^{34}$}

Atendi Miltom em uma terapia breve com foco na orientação profissional. Até sua chegada ao SOP, Miltom era acompanhado também por um psicólogo e por um psiquiatra em uma Unidade Básica de Saúde (UBS). Após um surto psicótico, que o fez passar alguns anos de vida apenas em sua casa, ele voltou a sair, iniciou o acompanhamento com um psicólogo e, por indicação deste, começou a freqüentar um cursinho popular e veio procurar o SOP. Logo em seu primeiro atendimento, informou-me que seu psicólogo havia sido transferido da UBS e que estaria sem acompanhamento até a chegada do próximo psicólogo, o que me deixou bastante apreensivo.

Miltom trazia com sua história as representações institucionais das duas organizações precedentes à sua chegada ao SOP: do cursinho que freqüentava e da UBS onde fazia seu tratamento psicológico e psiquiátrico. O maior efeito deste histórico não foi em sua transferência comigo, mas em minha contratransferência. Minha experiência de trabalho em cursinhos populares, além do viés psicoterapêutico, me criava uma ilusão de familiaridade das

\footnotetext{
${ }^{33}$ Nossa referência aqui é a discussão que fizer mos acerca da diferença em relação aos tabus em relação à morte do pai, que consideramos como fonte das relações institucionais, e os tabus relacionados ao convívio dos irmãos, que seriam referência para internalização das regras organizacionais.

${ }^{34}$ Nome fictício.
} 
dificuldades de seu cotidiano. O fato de Miltom ser acompanhado na UBS e do acompanhamento com o psicólogo ter sido interrompido, por sua vez, fez com que eu me sentisse responsável por esse cuidado. Favorecida por minha identificação com a Psicologia, que discutimos no tópico anterior, minha preocupação com a fragilidade de sua saúde mental e a responsabilidade que eu acreditava possuir em relação a sua recuperação (como psicólogo, como suposto conhecedor de seu cotidiano no cursinho) fez com que, de minha parte, o enquadre psicoterapêutico substituísse o da orientação profissional. A orientação transformouse em psicoterapia. O frágil vínculo ao conjunto organizacional que possuíamos favoreceu a construção de uma relação imaginária e distorcida com as instituições que atravessavam esse atendimento, relação que me deixou bastante vulnerável a transferência e a contratransferência como mera atuação de fantasmas, sem qualquer possibilidade de intervenção.

Atendi-o por um mês e meio e suas queixas relacionavam-se às suas relações no cursinho popular. Sentia-se perseguido e sobre essa sensação os atendimentos foram se desenvolvendo. A perseguição não estava apenas no que Miltom contava, mas também na maneira como se relacionava comigo, cauteloso, desconfiado. Durante as sessões, meu principal exercício era encontrar em seu discurso e, mais que isso, na própria transferência que estabelecia comigo, um lugar que não fosse o do perseguidor. Tinha medo de que estivessem tramando contra ele e que quisessem prendê-lo. Em contrapartida eu me esforçava para me diferenciar das pessoas que tramavam contra ele e para estabelecer um vínculo de confiança. Em um dos atendimentos:

- Quando saí daqui semana passada achei que tinham umas câmeras aí fora...

- Camêras? Aonde?

- Na sala aí do lado... a porta estava aberta...

[silêncio] 
- Tinha a sensação de que a câmera ia me seguindo enquanto eu passava.

- Aonde mais você teve essa sensação?

- No corredor. Parece que tem câmeras nas salas.

- É um corredor meio escuro mesmo, meio estranho, mas fique tranqüilo de que não há câmeras nele. Aqui na sala também você tem essa sensação... de que há câmeras?

- Não, aqui não...

Em outra sessão:

- Semana passada você tava com um negócio diferente aí na mesa...

- Semana passada?

- É.

- Ah sim, estava com um livro que era para meus estudos...

- Ah...

[silêncio]

- O que você pensou que era?

- Pensei que fosse um gravador, que você tivesse gravando nossa conversa.

[nesta sessão novamente tinha um livro sobre a mesa]

- Não, não era um gravador. Veja, era um livro como este [folheio o livro]. Vê é só um livro para meus estudos.

- Hum-hum. É que eu achei que era...

Sua demanda de atendimento não discriminava organizações ou instituições. Repetia no SOP e no cursinho as relações que o levaram também a UBS, relações de persecutoriedade. Apesar de Miltom apresentar as organizações com pouca diferença entre si, experimentando repetidas inserções persecutórias aos conjuntos, ele demonstrava reconhecer a potência da dimensão institucional e organizacional, pois era o contexto organizacional/institucional que despertava sua transferência. Esta se apresentava apenas em 
seu aspecto mais abrangente, como fenômeno que introjetava as instituições e organizações transformando-as em objetos da dinâmica interna de Miltom. Seu ego e suas defesas não davam conta das angústias e do conflito pulsional que vivia que transbordavam de tal maneira, que a transferência necessitava de pouco para ser produzida. A estrutura das organizações era suficiente para que a transferência fosse produzida, sendo o contexto de atendimento apenas uma via favorável de expressão e não de produção. Sentia-se aflito no espaço das organizações e na presença de um conjunto de pessoas; a relação dual que estabelecia comigo era mais fácil de lidar para Miltom do que o antes e depois das sessões. Suas relações com os grupos e com as hierarquias do cursinho onde estudava eram também muito mais angustiantes do que relações específicas com este ou aquele colega em especial (eram ou grupos ou coordenadores e diretores que ele entendia como ameaçadores).

Apesar da condição de relação dual ser menos ameaçadora para Miltom, não era garantia para que não fosse arrastado para mesma dinâmica que ele estabelecia com as organizações. Com sua postura assustada e retraída, e depois com sua desconfiança explícita acerca de eu carregar um gravador escondido para a sessão, ele expressava que a linha entre minha inserção mais amistosa em sua transferência e o lugar comum, de perseguidor, que as organizações ocupavam em sua fantasia, era tênue. Minha sensação durante os atendimentos era a de um esforço para me diferenciar da instituição que ele enxergava como perseguidora, para mostrar uma outra possibilidade. Por sua transferência, sentia o quanto era pesado para Miltom estar sempre alerta contra tudo e contra todos e me esforçava para vencer estas defesas e estar ao seu lado. Pensava que se ele permitisse que eu estivesse ao seu lado, se ele me percebesse como um aliado, poderia ajudá-lo a compreender que o mundo poderia não ser tão ameaçador.

Numa sessão em que Miltom demonstra bastante desconfiança quanto às minhas falas, Miltom diz: 
- Tem uma delegacia na aqui na USP né?

- Delegacia... aonde você viu uma delegacia?

- Semana passada quando eu estava saindo de ônibus, eu vi uma placa da polícia.

- Ah sim há mesmo [Miltom referia-se a Academia de Polícia localizada na entrada principal da USP]

Mais tarde, me pergunta na mesma sessão:

- Você trabalha no que aqui na USP?

- Você quer saber se eu sou funcionário?

- É, o que você faz aqui? [percebo em sua fala uma certa inquietação]

- Estou na pós-graduação, mas pode ficar tranqüilo que a responsabilidade pelo seus atendimento é minha e eles não serão interrompidos [pensava nesse momento que suas perguntas expressassem o receio de que eu o abandonasse como o psicólogo da UBS].

- Ah...

[silêncio]

- Acho que semana passada eu te vi na televisão.

- [fico surpreso e um pouco apreensivo, por estar certo de que não havia aparecido na TV] Na televisão? Aonde?

- Não sei, a TV estava ruim acho que era aqui na USP.

- E o que você viu.

- Tinha um professor aqui da psicologia falando sobre violência, o nome dele era Paulo, ele era japonês e eu achei que fosse você.

- [neste momento entendo do que se trata] Ah, não era eu não. Era um professor aqui do instituto que trabalha com violência.

- Ah...

[silêncio] 
- Achei que você estava um pouco preocupado quando me perguntou sobre o meu trabalho, porque você perguntou antes no que eu trabalhava?

- É que eu achei que você trabalhasse na polícia.

- Na polícia? Como assim...

- É. Como eu vi a delegacia aqui na USP também...

Rapidamente procuro esclarecer que não tenho nenhum vínculo com a polícia e ao mesmo tempo tento compreender com ele o caminho que o levara a essa conclusão: a delegacia de polícia na porta de entrada da universidade e a violência anunciada por aquele que reunia as características pelas quais ele me identificava. Sentia-me de mãos atadas frente às associações de Miltom. Enquanto procurava me diferenciar do resto da organização, ele me enxergava como uma organização. Enquanto Miltom se sentia perseguido concretamente pelas organizações que ele freqüentava, contratransferencialmente sentia-me também encurralado, pois meu nome, minha descendência, minha escolha profissional, a universidade em que eu estudava e trabalhava, tudo o que eu lhe apresentava era inserido em sua fantasia. Nada era preservado. Apesar de também não conseguir escapar a este registro de aprisionamento, continuava pensando que se pudesse me aproximar de Miltom, fazendo com que ele confiasse em mim e não me visse mais como uma ameaça e potencial, teria uma chance de modificar esta situação.

Posteriormente, ocorreu apenas mais uma sessão. Apesar das dificuldades que sentia durante os atendimentos, a cada sessão Miltom contava mais sobre suas angústias. Contou-me nesta sessão o que o levara a passar tantos anos em casa com medo. Atendo-me ao que é essencial para o entendimento do caso, ele acreditava que seu ex-chefe, a quem ele atribuía bastante poder, o suficiente para manipular todas as organizações, inclusive a polícia, encarcerava pessoas no porão do prédio onde ele trabalhava como porteiro. Seu medo era que, tendo descoberto isso, fosse o próximo a ser pego por seu chefe. Perguntei se hoje, após o 
tratamento psicológico e psiquiátrico, ainda acreditava que seu ex-chefe poderia prendê-lo. Respondeu-me que sim. Pela primeira vez durante os atendimentos senti que estava ao seu lado. E não soube o que fazer. Sofri nesse atendimento o impacto da angústia que Miltom era tomado, e só pude comunicar-lhe ao final que continuaríamos trabalhando na semana seguinte.

Miltom interrompeu as sessões. Faltou na semana seguinte, e após um contato que tivemos por telefone foi lacônico e afirmou que não queria mais continuar com o processo. Não pude sair do lugar perseguidor em que eu era colocado sem passar para seu lugar de perseguido, o que me foi bastante angustiante e culminou na interrupção do processo.

Realizemos agora uma síntese, com nossas elaborações posteriores ao fim dos atendimentos. As múltiplas instituições que carregava em mim, minha identidade profissional, meu pertencimento a universidade, minha etnia, meu nome, confluíram para uma realização dos fantasmas de Miltom, por meio de sua transferência que introjetava todos os objetos que lhe eram apresentados. Nesse momento, ego e dinâmica institucional se fundiam, com a dinâmica institucional estando sujeita aos conflitos do ego. Destituídas as funções vinculares da instituição e da organização, esta não fazia referência a nenhum contrato de pertencimento, a nenhum conjunto, e somente servia de suporte objetal para a cena fantasmática que fazia Miltom sofrer. Sua dinâmica egóica se expandia para a cena institucional, procurando uma possibilidade de expressão da angústia, mas esta expansão ocorria de maneira tão radical que minava toda a possibilidade do contexto institucional oferecer alguma resistência a esta cena fantasmática. As organizações tornavam-se mero suporte para a repetição da cena fantasmática, veículo de uma transferência que as eliminava enquanto objetos.

A análise da transferência de Miltom nos oferece também um outro aspecto, positivo. Ferenczi apontava que nas organizações o sujeito podia deslocar suas tendências recalcadas para uma esfera onde elas poderiam ser vividas sem culpa. No caso de Miltom não se tratava 
de culpa, mas de seus fantasmas persecutórios que eram transferidos para as organizações. Primeiro e de forma, mais intensa, para o seu trabalho, e para a figura de seu chefe. Depois para o cursinho e para sua direção. Por último para os atendimentos no SOP e para mim, seu psicólogo. Em todas essas organizações Miltom relatava seu temor acerca de um perigo, de uma vigilância que o ameaçava. Miltom transferia para as organizações suas pulsões parciais agressivas, arcaicas, deslocava para a dinâmica das organizações suas angústias persecutórias. Essa transferência não adaptada ao meio social não permitia uma experiência sem culpa, porém era uma maneira de seu ego se proteger. Frente ao terror de suas angústias de morte arcaicas a transferência às organizações oferecia alguma possibilidade de unidade à emergência de suas pulsões parciais. Apesar da angústia de ter que se proteger da organização, a unidade que ela oferecia a suas pulsões permitia que em algum lugar Miltom conseguisse se esconder, seja em seu quarto, seja recusando meus atendimentos. Além disso, a complexidade das organizações permitia que transferências amistosas também pudessem se estabelecer em seu interior, como foram os atendimentos com o psicólogo da UBS e como por algum tempo foram os atendimentos comigo, quando fora da sala de atendimento ele se sentia perseguido, mas a mim conseguia confessar seus medos.

No caso de Miltom a transferência não é condicionada pelo alívio da culpa, mas sim é condição de seu ego manter-se íntegro. Se as instituições e organizações não pudessem ser introjetadas por seu ego, este não teria recursos para lidar com as pulsões parciais. Ferenczi formula que é pela extensão do ego, pela extensão de seu amor narcísico, que o homem pode amar os objetos. Vimos, anteriormente, a transferência como introjeção expressa como um mecanismo que servia principalmente para expressão das pulsões libidinais. Pelo caso de Miltom, entretanto, podemos formular que essa extensão do ego não serve apenas como possibilidade de amor aos objetos, mas também como possibilidade de expressão das pulsões parciais de morte, possibilidade de expressão de um ódio a si. Dentro dessa análise podemos 
identificar que as organizações e as instituições não apenas servem para um alívio da culpa neurótica, mas podem também se configurar em importantes instrumentos para que tanto terapeuta quanto paciente possam lidar com as pulsões parciais e suas manifestações. Encontramos aqui uma possibilidade em que os recursos da organização e da instituição podem se unir aos do setting de atendimento em benefício do tratamento. Entretanto devemos estar atentos que a expressão desse ódio como perseguição institucional, se em um primeiro momento permite a sobrevivência do ego, pode também desdobrar-se em sua destruição, caso não seja equilibrado pelo depósito e expressão das pulsões de vida também na instituição.

Em sua transferência no SOP observamos ainda o fenômeno da transferência de transferência. A representação da polícia como agente da perseguição que Miltom vivera em seu trabalho era transferida para a universidade na forma da delegacia de polícia e do tema do enfrentamento da violência enunciado pelo professor da universidade. Podemos notar no caso de Miltom que ainda que sua transferência ocorra de maneira indiscriminada nas diferentes relações organizacionais ${ }^{35}$, as representações sociais dessas organizações e das instituições que a sustentam aderem aos seus fantasmas. Subestimamos durante os atendimentos o quanto a boa referência que Miltom trazia de seu psicólogo na UBS favorecia a transferência amistosa que a princípio estabeleceu comigo. Como contratransferencialmente sentia-me afogado nos grupos e papéis institucionais em que Miltom me colocava não pude perceber que uma dessas representações me era favorável. Recalcada a parte favorável de minha inserção institucional, me debatia na transferência de Miltom buscando uma pureza impossível de relação entre sujeitos livres de instituições ou organizações. O não reconhecimento desta transferência de transferência que se estabelecia favoravelmente ao processo terapêutico fez com que eu construísse, imerso em minha contratransferência, uma

\footnotetext{
${ }^{35}$ Seu conflito pulsional é tão intenso que a produção da transferência ocorre na maioria de suas relações, e não apenas sob condições favoráveis.
} 
relação imaginária e cindida na qual somente unidos enquanto sujeitos, superaríamos as mazelas impostas pelas instituições.

Minha contratransferência no caso de Miltom foi bastante angustiante. Despertou aspectos denegados de minha vinculação com a instituição Psicologia, fez com que eu me questionasse, inclusive em análise pessoal, acerca de minha identidade como psicólogo. Sentia-me também perseguido, também cercado em minhas ações. Como trabalhamos acerca das identificações pelo sintoma, que são uma das bases do pertencimento a qualquer conjunto, o ponto de coincidência entre os egos deve ser mantido reprimido. Minha vinculação mais primitiva com as instituições eram exploradas, testadas. Sua transferência desvelava este ponto de coincidência, privando-me de minha condição de singularidade tão radicalmente que esta condição extrapolava o enquadre analítico. A sessão em que Miltom confundiu-me com um outro ator da organização, foi bastante impactante neste sentido. Como reação a essas sensações de encurralamento, idealizava que um encontro nosso, como sujeitos singulares, seria a saída para essas angústias. Porém quando esse encontro aconteceu a idealização desmanchou-se, e não havia mais nada que sustentasse a relação terapêutica. Era por ser psicólogo que eu procurava tratá-lo. Era por eu ser psicólogo que ele aceitava me escutar. Porém era tão angustiante a absorção indiscriminada das instituições e das organizações que esta condição foi por mim recalcada.

O fantasma de Miltom dava pouco espaço para emergência de um sujeito, que estava sempre na condição de perseguido. Conseqüentemente nosso pertencimento a USP não era reconhecido como pertencimento a um conjunto, mas fundia-se numa única massa compacta de representação. Tal condição era perturbadora, na medida em que mobilizava nossos próprios fantasmas de aniquilação pelo conjunto, de indiscriminação. Só podia reconhecer minha condição organizacional quando esta me servia de defesa frente a esta angústia, me diferenciando do papel que ele enunciava. Entendi, posteriormente, que quando reagi a seu 
questionamento sobre meu vínculo organizacional reafirmando-o, como via redentora e asseguradora para os problemas que ele nos apresentava, procurava um lugar de segurança no enquadre não para Miltom, mas para mim. A fragilidade de meu vínculo organizacional, ainda mais fragilizado por uma intensa contratransferência negativa, desdobrou-se em um enquadre vulnerável, distorcido, que não foi suficiente para conter e suportar as pressões da emergência transferencial.

Como apontamos no caso de Mara a dinâmica organizacional e institucional está presente no setting terapêutico independentemente da vontade do terapeuta. No caso de Miltom, o fato do enquadre ter sofrido os desvios que mencionamos em nossa apresentação do SOP, fez com que os limites entre pertencimento ou não pertencimento institucional ficassem pouco pautados pela organização SOP e mais direcionados por nossas representações institucionais imaginárias. Este caso ajuda-nos a acrescentar um novo tópico relevante aos atendimentos em organizações: a importância da referência ao conjunto organizacional quando se está atuando segundo referências institucionais. A referência institucional descolada de um conjunto que enuncia suas regras faz com que seus ideais sejam distorcidos pelos fantasmas individuais de cada sujeito, e se tornem extremamente vulneráveis a contratransferência. A referência ao conjunto organizacional cumpre uma função castradora na medida em que enuncia as regras de pertencimento e faz referência a um conjunto de sujeitos que oferece resistência a nossos desejos totalizantes. Talvez esta clareza de minha parte não impedisse Miltom de abandonar sua orientação, mas certamente promoveria diminuiria minha atuação contratransferencial e, conseqüentemente, ampliaria os recursos de trabalho na transferência. 


\section{Considerações finais}

Ao final de nosso trabalho, podemos afirmar que o principal exercício, ao longo de toda nossa argumentação, foi delimitar uma lente para enxergar o trabalho do psicanalista nas instituições que pudesse ser utilizada por qualquer psicanalista, sem que o mesmo precisasse se intimidar com o tema das instituições como um campo hostil ou adverso ao conhecimento psicanalítico. Não se tratou de uma análise institucional psicanalítica ou de grupos, nem da análise do psicanalista na instituição, mas das condições clínico-teóricas que ora possibilitam, ora não o exercício da prática psicanalítica nas instituições. Procuramos demonstrar, metapsicologicamente, que um tratamento psicanalítico é possível nas instituições, que apresenta riscos e desafios, mas que será realizável na medida em que a instituição também for objeto de análise a cada caso e a cada sessão.

Em relação à transferência, pilar da prática analítica, ao constatarmos que sua produção relaciona-se a um contexto favorável, de assimetria de saberes, e que não está vinculada necessariamente a existência do analista, percebemos que as instituições e organizações têm muito a interferir em sua manifestação. Por funcionarem sobre um princípio geral de introjeção dos objetos do mundo para o funcionamento psíquico, a transferência nas instituições/organizações faz com que estas se tornem um importante continente de elaboração psíquica. Nelas, pulsões e defesas primitivas podem rearranjar-se e fantasmas arcaicos podem ser ressignificados pela associação a papéis institucionais. A cena institucional multiplica as potencialidades da transferência, ao mesmo tempo em que, por essa pluralidade, dificulta sua leitura e interpretação.

O instrumento de que o psicanalista dispõe para lidar com essa transferência intensa e plural foram elencados por nós como o controle e a utilização da contratransferência, as experiências da técnica ativa e as formulações de Ferenczi acerca da elasticidade da técnica 
psicanalítica, do tato psicológico e do princípio de relaxamento. Dentro dessas possibilidades o psicanalista primeiro deve ter conhecimento de suas próprias limitações frente aos afetos despertados pelo contexto transferencial e institucional (controle da contratransferência). A partir disso ele poderá trabalhar na transferência (experiências da técnica ativa e do princípio de relaxamento), ou interpretá-la (a partir de uma análise da contratransferência e tendo como recurso o tato psicológico).

Demonstramos também que o trabalho, por parte do analista, na transferência em contexto institucional, passa por uma compreensão do que é este contexto institucional para o sujeito. Delimitamos então o conceito de instituição e organização. A instituição refere-se a uma representação da cultura que dá sentido aos conjuntos sociais. A organização refere-se a um conjunto de sujeitos orientados por um conjunto de regras e por uma hierarquia, em um espaço e em um tempo. Com as instituições, o sujeito lida de maneira internalizada e ambivalente, nos moldes da relação que cada membro da frátria tinha com o pai morto da horda. Com as organizações, o sujeito se relaciona tal como com os membros da frátria, com o obedecimento das regras condicionado pelos benefícios conquistados pela condição de conjunto.

Ainda dentro dessa análise da dinâmica institucional sobre a qual se desenvolvem os atendimentos, analisamos qual seria a natureza da ligação entre o psiquismo do sujeito e as marcas das instituições sociais. Percebemos que essa relação está na base da própria constituição do sujeito. Pela função de porta-voz da mãe, as instituições e conjuntos sociais já se fazem presentes como marcas nos primeiros objetos a serem percebidos pelo infans. No complexo de Édipo encontramos outra marca fundamental para o advento do sujeito, com as instituições e os conjuntos sociais sendo fundamentais para que o sujeito abandone o registro onipotente para se configurar como indivíduo da cultura. Avaliamos também como se dá a relação dialética entre os sujeitos e as instituições, através do contrato narcisista, e 
discorremos também sobre seu negativo necessário, o pacto denegatório. Ainda o campo da dinâmica inconsciente das instituições, procuramos demonstrar como o próprio enquadre psicanalítico se apresenta como uma organização e instituição para os atendimentos, o que nos ajuda a perceber que a atuação do psicanalista nas organizações não promove a tensão apenas entre sujeito e instituições/organizações, mas também promove a tensão entre instituição psicanalítica e as demais instituições.

Por fim, nas análises de casos, procuramos articular alguns conceitos que desenvolvemos metapsicologicamente com situações clínicas que experimentamos na prática. Nos casos, percebemos que algumas diretrizes podem nortear o trabalho nas organizações. Primeiramente o analista deve preocupar-se em compreender quais são as ligações inconscientes que o mantém vinculado às organizações, estando para isso disposto a analisálas e inclusive a abandoná-las. Além disso, percebemos que a manifestação da transferência nas organizações/instituições pode oferecer uma importante possibilidade de elaboração da pulsões parciais, na forma de um depósito para que elas se expressem apenas institucionalmente. As organizações e as condições institucionais, pela complexidade de suas relações e por ser depositária da onipotência da qual, desde o Édipo, o sujeito não pode mais dispor, oferecem ao sujeito uma unidade para que suas pulsões parciais mais agressivas possam se expressar. Se esta expressão puder ser trabalhada pelo psicanalista, as organizações podem configurar-se não apenas como um obstáculo para um processo analítico, mas também como um importante instrumento terapêutico.

Discutimos ainda a importância de que o conjunto organizacional opere uma resistência castradora aos nossos impulsos totalizantes e onipotentes, atuados transferencial e contratransferencialmente. Não é a condição institucional e organizacional em si que oferece resistência ao processo analítico, pois ambas podem ser referência inclusive do que há de mais singular em cada sujeito, na fabricação de seus desejos. Porém o esquecimento ou a 
negligência, por parte do analista, do estatuto castrador das instituições e das organizações pode operar contra qualquer tentativa de intervenção analítica.

Por fim gostaríamos de elencar algumas questões e hipóteses que nos foram despertadas no decorrer desta pesquisa, mas que extrapolaram os limites deste trabalho. A primeira questão refere-se ao posicionamento organizacional e institucional dos psicanalistas. Consideramos que o retrato que conseguimos desenhar sobre a prática psicanalítica nas instituições foi suficiente para que os psicanalistas que atuam nas mais diversas áreas possam contar com boas chaves para a compreensão de seu contexto de trabalho, cientes dos desafios que esta prática lhes impõe. No entanto, nos fica a questão de saber o quanto os psicanalistas que trabalham nas instituições, cada vez mais numerosos, serão capazes de resolver a tensão entre psicanálise e instituições que ocorre no interior da lógica psicanalítica. Explico-me melhor: constatamos, em certo momento, que a psicanálise depende de um reconhecimento do discurso psicanalítico por parte da instituição, para que a transferência possa ser trabalhada e interpretada sem boicotes externos; entretanto o reconhecimento do discurso psicanalítico depende de uma afirmação por parte dos psicanalistas da parcela já institucionalizada da psicanálise. O paradoxo a que chegamos é que talvez para fazer psicanálise nas instituições é preciso fazer síntese da psicanálise. E caso se faça essa síntese da psicanálise, e se defenda um discurso psicanalítico no interior das diversas instituições, o resultado será ainda psicanalítico? Dado o histórico do movimento psicanalítico (nos referimos aqui as diversas e significativas rupturas) podemos nos arriscar a dizer que mesmo em sua institucionalização os psicanalistas tem mostrado mais vocação a análise do que a síntese, e assim tem construído sua identidade.

Uma segunda questão que nos ocorre, para esse crepúsculo do trabalho, refere-se à psicanálise fora do setting. Se demonstrarmos que o fenômeno transferencial se espalha pelas organizações, fazendo uso das diversas representações institucionais, inclusive se 
beneficiando, por vezes, desse contexto, por que não avaliarmos o seguinte quadro: o psicanalista sem seu enquadre de atendimento, ou de tratamento. Quais seriam as possibilidades e limites da prática psicanalítica sem o dispositivo do enquadre de atendimento? Se a transferência nas organizações não respeita as paredes da sala de atendimento, poderia o psicanalista continuar trabalhando quando abdicasse delas? Sabemos que já existem experiências práticas de atendimentos, que muitas vezes por limitações concretas de não haver uma sala ou momento reservado ocorre ao livre e em meio a outras pessoas. Entretanto estas experiências são tomadas sempre como uma superação de adversidades por parte do psicanalista. Diferente do quanto as diversidades podem ser superadas, o que nos questionamos aqui é o quanto esta prática pode, em determinadas situações, ser tão ou mais analítica do que o dispositivo clássico de uma sala fechada, com analista e analisando. Trata-se de uma questão da qual nos aproximamos, mas que necessitará de um trabalho futuro para ser respondida.

Quisemos, com esse trabalho, contribuir para os alicerces e possibilidades da prática psicanalítica nas instituições. Para tanto precisamos não só oferecer caminhos, mas apontar limites, ligados especialmente à condição de sujeito do psicanalista e as características das instituições e organizações que abafariam a possibilidade de uma psicanálise. O desenvolvimento desta prática nas instituições, entretanto, dependerá sempre, como foi ao longo da história da psicanálise, da disposição metodológica dos psicanalistas em enfrentar aquilo que resiste, em buscar alternativas em que tudo aponta para o único. Enquanto houverem psicanalistas munidos desse espírito é possível que tenhamos práticas psicanalíticas nas instituições. 


\section{Referências Bibliográficas}

AULAGNIER, P. (1975). A violência da interpretação. Rio de Janeiro: Imago Editora, 1979.

BAREMBLITT, G. Compêndio de análise institucional e outras correntes: teoria e prática. Belo Horizonte: Editora Instituto Félix Guatarri, 2002.

BERLINCK, M. T. O psicanalista fora da IPA. In: Psicopatologia Fundamental. São Paulo: Escuta, 2000. p. 355-368.

BLEGER, J. (1970). O grupo como instituição e o grupo nas instituições. In: Temas de psicologia. São Paulo: Martins Fontes, 2003. p. 101-122.

. Psicanálise do enquadramento psicanalítico. In: Simbiose e Ambigüidade. Rio de Janeiro: Francisco Alves, 1988. p. 311-328.

CASTORIADIS, C. (1975). A instituição social-histórica: o indivíduo e a coisa. In: A instituição imaginária da sociedade. Rio de Janeiro: Paz e Terra, 1982. p. 315-383.

DEBIEUX, M. O não-dito como operador na clínica com crianças e adolescentes. Site Estados Gerais em Psicanálise, 2001. Disponível em: www.estadosgerais.org/gruposvirtuais/o_nao_dito.shtml. Acesso em: 19 de fevereiro de 2009.

DUPONT, J. (1968). Introdução. In: FERENCZI, S. Obras completas psicanálise III. São Paulo: Martins Fontes, 1993. p. VII-XII.

ENDO, P. C. Freud, Jung e o homem dos lobos: percalços da psicanálise aplicada. Ágora, Rio de Janeiro, v. IV, n. 1 jan/jun 2001 115-130, 2001.

O corpo, o silêncio e a fala em análise: percursos da escuta analítica. 1997. Dissertação (Mestrado em Psicologia Clínica) - Pontifícia Universidade Católica de São Paulo, São Paulo. 1997.

ENRIQUEZ, E. (1983a) Apresentação. In: Da horda ao Estado - Psicanálise do vínculo social. Rio de Janeiro: Jorge Zahar Editor, 1991. p. 11-26.

(1983b) Totem e tabu: o advento do social. In: Da horda ao Estado Psicanálise do vínculo social. Rio de Janeiro: Jorge Zahar Editor, 1991. p. 28-46.

. (1983c) Psicologia das massas e análise do ego: as metamorfoses da função social. In: __ Da horda ao Estado - Psicanálise do vínculo social. Rio de Janeiro: Jorge Zahar Editor, 1991. p. 47-78.

. O trabalho da morte nas instituições. In: A instituição e as instituições. São

Paulo: Casa do Psicólogo, 1991. p. 53-79. 
FÉDIDA, P. Amor e morte na transferência. In: A clínica psicanalítica: estudos. São Paulo: Editora Escuta, 1988. p. 21-66.

FERENCZI, S. (1909). Transferência e introjeção. São Paulo: Martins Fontes, 1991. p. 77108. (Obras completas: psicanálise I).

. (1911). Sobre a História do movimento psicanalítico. São Paulo: Martins Fontes, 1991. p. 145-154. (Obras completas: psicanálise I).

(1912). O conceito de introjeção. São Paulo: Martins Fontes, 1991. p. 181-184. (Obras completas: psicanálise I).

• (1918). A técnica psicanalítica. São Paulo: Martins Fontes, 1992. p. 357-368. (Obras completas: psicanálise II).

- (1920). Prolongamentos da "técnica ativa” em psicanálise. São Paulo: Martins Fontes, 1993. p. 109-126. (Obras completas: psicanálise III).

(1924). Thalassa: uma teoria da genitalidade. São Paulo: Martins Fontes, 1993. p. 255-325. (Obras completas: psicanálise III).

. (1925). Psicanálise dos hábitos sexuais. São Paulo: Martins Fontes, 1993. p. 327-360. (Obras completas: psicanálise III).

. (1926) Contra-indicações da técnica ativa. São Paulo: Martins Fontes, 1993. p. 365376. (Obras completas: psicanálise III).

. (1928). Elasticidade da técnica psicanalítica. São Paulo: Martins Fontes, 1992. p. 2536. (Obras completas: psicanálise IV).

. (1930). Princípio de relaxamento e neocatarse. São Paulo: Martins Fontes, 1992. p. 53-68. (Obras completas: psicanálise IV).

. (1933). Confusão de língua entre os adultos e a criança. São Paulo: Martins Fontes, 1992. p. 97-106. (Obras completas: psicanálise IV).

FIGUEIREDO, L. C. Acerca do que Freud infelizmente considerou alheio ao seu interesse naquele momento. Psicanálise e universidade, São Paulo, n. 9 e 10, p. 35-47, jul./dez. 1998 jan./jun. 1999.

FREUD, A. (1946). O ego e os mecanismos de defesa. Rio de Janeiro: Editora Civilização Brasileira S. A., 1977.

FREUD, S. (1893-5). Estudos sobre a histeria. Rio de Janeiro: Imago Editora, 1974. (Edição standard brasileira das obras completas de Sigmund Freud, vol. II) 
Imago Editora, 1972. p. 5-119. (Edição standard brasileira das obras completas de Sigmund Freud, vol. VII).

. (1912a). A Dinâmica da transferência. In: . Artigos sobre a técnica / Sonhos no folclore e outros trabalhos. Rio de Janeiro: Imago Editora, 1976. p. 31-43. (Pequena coleção das obras de Freud).

(1912b). Recomendações aos médicos que exercem a psicanálise. In:

Artigos sobre a técnica / Sonhos no folclore e outros trabalhos. Rio de Janeiro: Imago Editora, 1976. p. 45-59. (Pequena coleção das obras de Freud).

(1913a). Sobre o início do tratamento. In:

. Artigos sobre a técnica / Sonhos

no folclore e outros trabalhos. Rio de Janeiro: Imago Editora, 1976. p. 61-88. (Pequena coleção das obras de Freud).

(1913b). Totem e tabu. In: Totem e tabu e outros trabalhos. Rio de Janeiro: Imago Editora, 1974. p. 20-191. (Edição standard brasileira das obras completas de Sigmund Freud, vol. XIII).

(1914). Sobre o narcisismo: uma introdução. In:

A história do movimento psicanalítico, artigos sobre metapsicologia e outros trabalhos. Rio de Janeiro: Imago Editora, 1974. p. 89-119. (Edição standard brasileira das obras completas de Sigmund Freud, vol. XIV).

. (1915). Observações sobre o amor transferencial. In: O caso Schreber, artigos sobre técnica e outros trabalhos. Rio de Janeiro: Imago Editora, 1976. p. 208-221. (Edição standard brasileira das obras completas de Sigmund Freud, vol. XII).

(1916-17). Conferência XXVII: transferência. In:

Conferências introdutórias sobre psicanálise (Parte III). Rio de Janeiro: Imago Editora, 1976. p. 503521. (Edição standard brasileira das obras completas de Sigmund Freud, vol. XVI).

(1916-17). Conferência XXVIII: terapia analítica. In: Conferências introdutórias sobre psicanálise (Parte III). Rio de Janeiro: Imago Editora, 1976. p. 523539. (Edição standard brasileira das obras completas de Sigmund Freud, vol. XVI).

(1918-19). Linhas de progresso na terapia psicanalítica. In: . História de uma neurose infantil e outros trabalhos. Rio de Janeiro: Imago Editora, 1976. p. 201-211. (Edição standard brasileira das obras completas de Sigmund Freud, vol. XVII).

(1920). Além do princípio do prazer. In: Além do princípio do prazer / Psicologia de grupo e outros trabalhos. Rio de Janeiro: Imago Editora, 1976. p. 17-85. (Edição standard brasileira das obras completas de Sigmund Freud, vol. XVIII).

- (1921). Psicologia de grupo e análise do ego. In: Além do princípio do prazer / Psicologia de grupo e outros trabalhos. Rio de Janeiro: Imago Editora, 1976. p.91179. (Edição standard brasileira das obras completas de Sigmund Freud, vol. XVIII). 
(1940). Esboço de psicanálise. In:

Moisés e o monoteísmo, esboço de psicanálise e outros trabalhos. Rio de Janeiro: Imago Editora, 1996. p. 157-221. (Edição standard brasileira das obras completas de Sigmund Freud, vol. XXIII).

HAYNAL, A. A técnica em questão: controvérsias em psicanálise: de Freud e Ferenczi a Michael Balint. Tradução Giselle Groeginga de Almeida. São Paulo: Casa do Psicólogo: Clínica Roberto Azevedo, 1995.

HORNEY, K. (1939). O conceito de transferência. In: Rio de Janeiro: Editora Civilização Brasileira S. A., 1959. p. 127-137.

Novos rumos na psicanálise.

KAËS, R. Realidade psíquica e sofrimento nas instituições. In: A instituição e as instituições. São Paulo: Casa do Psicólogo, 1991. p. 1-39.

O grupo e o sujeito do grupo: elementos para uma teoria psicanalítica do grupo. Tradução José de Souza e Mello Werneck. São Paulo: Casa do Psicólogo, 1997. 333 p.

O interesse da psicanálise para considerar a realidade psíquica da instituição. In: CORREA, O. B. R. et all. Vínculos e instituições: uma escuta psicanalítica. São Paulo: Escuta, 2002. p. 11-31.

LAGACHE, D. (1951). A transferência. São Paulo: Martins Fontes, 1990. 154 p.

LAPLANCHE, J. A tina: a transcendência da transferência. São Paulo: Martins Fontes, 1993. 257 p. (Problemáticas V)

LIMA,M.; ALTOÉ, S. (orgs.) Psicanálise, clínica e instituição. Rio de Janeiro: Rios Ambiciosos, 2005.

MEZAN, R. Psicanálise e cultura, psicanálise na cultura. In: Interfaces da psicanálise. São Paulo: Companhia das Letras. 2002. p. 317-392.

PLOM, M. Ordem e subversão no movimento psicanalítico: o fantasma de Jung. Ágora, Rio de Janeiro, v. V, n. 2 jul/dez 2002 317-328, 2002.

REVISTA PSICOLOGIA USP. São Paulo: Instituto de Psicologia da Universidade de São Paulo. 1990-. Trimestral. ISSN 0103-6564. v. 12, n. 2, 2001.

ROUDINESCO, E.; PLOM, M. Dicionário de Psicanálise. Rio de Janeiro: Jorge Zahar, 1998.

SOARES, J. M. Possibilidades e limites do tratamento psicanalítico da psicose infantil em instituições de saúde mental. 2007. Dissertação (Mestrado em Psicologia Escolar e do Desenvolvimento Humano) - Instituto de Psicologia, Universidade de São Paulo, São Paulo. 2007.

VOLnOVICH, J. C. As instituições psicanalíticas. Pulsional Revista de Psicanálise, São Paulo, ano XIII, n. 137, set. 2000, p. 97-101, 2000. 
WINNICOTT, D. W. (1947) O ódio na contratransferência. In: Da pediatria à psicanálise. Rio de Janeiro: Imago Editora, 2000. p. 277-287. 